\title{
Lexical Co-occurrence and Lexical Inheritance. Emotion Lexemes in German: A Lexicographic Case Study
}

\author{
Igor A. Mel'čuk, Département de Linguistique, \\ University of Montreal, Canada, and \\ Leo Wanner, Institut für Linguistik/Romanistik, \\ University of Stuttgart, Germany
}

\begin{abstract}
In the present paper, we tackle the problem of the compact and efficient representation of restricted lexical co-occurrence information in the lexicon along semantic lines. The theoretical framework for this study is the Meaning Text Theory (MTT) and, more specifically, the lexicographic part of MTT - the Explanatory Combinatorial Dictionary (ECD), which contains for each lexeme (i) its semantic definition, (ii) a systematic description of its restricted lexical co-occurrence in terms of Lexical Functions (LF), and (iii) its Government Pattern. The data domain is the semantic field of emotion lexemes in German. In order to represent the restricted lexical co-occurrence (or collocations) of the lexemes in this field, we suggest the following procedure:
\end{abstract}

1. Construct approximate descriptions of their meaning, i.e. what we call the abridged lexicographic definitions. Formulated in terms of semantic features, these definitions are supposed to provide as much semantic information as necessary for establishing correlations between the semantic features of a lexeme and its collocates.

2. Specify their syntactic Government Patterns, which are needed for a clearer picture of their cooccurrence - syntactic as well as lexical.

3. Specify their restricted lexical co-occurrence with the verbs chosen.

4. Establish correlations between the values of LFs and the semantic features in the abridged definitions of the emotion lexemes.

5. Based on these correlations, extract recurrent values of LFs (and recurrent Government Patterns) from individual lexical entries and list them under what we call the generic lexeme of the semantic field under study - in this case, GEFÜHL 'emotion'. This leads on the one hand, to "compressed" lexical entries for emotion lexemes, and on the other hand, to the creation of a lexical entry of a new type: the "public" entry of a generic lexeme.

Keywords: LEXICOGRAPHY, LEXICON, GERMAN EMOTION LEXEMES, LEXICAL COOCCURRENCE, COLLOCATIONS, MEANING TEXT THEORY, LEXICAL FUNCTIONS, SEMANTIC FEATURES, SEMANTICO-LEXICAL CORRELATIONS, INFORMATION EXTRACTION, INHERITANCE, INDIVIDUAL LEXICAL SUBENTRY, PUBLIC LEXICAL SUBENTRY 
Opsomming: Leksikale verbindinge en leksikale erfenis. Emosielekseme in Duits: 'n Leksikografiese gevallestudie. In hierdie dokument bespreek ons die probleem van die bondige en doeltreffende voorstelling volgens semantiese beginsels van inligting oor beperkte leksikale verbindinge in die leksikon. Die teoretiese raamwerk vir hierdie studie is die Teorie pan Betekenisteks (MTT) en, meer spesifiek, die leksikografiese deel van MTT — die Explanatory Combinatorial Dictionary (ECD), wat die volgende vir elke lekseem bevat: (i) sy semantiese definisie, (ii) ' $n$ sistematiese beskrywing van sy beperkte leksikale verbindinge in terme van Leksikale Funksies en (iii) sy Bepalingspatroon. Die inligtingsterrein is die semantiese veld van emosielekseme in Duits. Om die beperkte leksikale verbindinge (of kollokasies) van die lekseme in hierdie veld voor te stel, doen ons die volgende prosedure aan die hand:

1. Stel benaderde beskrywings van hulle betekenis op, d.i. wat ons die afgekorte leksikografiese definisies noem. Geformuleer in terme van semantiese kenmerke, is hierdie definisies veronderstel om soveel semantiese inligting te voorsien as wat nodig is om korrelasies tussen die semantiese kenmerke van 'n lekseem en sy kollokasies vas te stel.

2. Spesifiseer hulle sintaktiese Bepalingspatrone, wat nodig is vir 'n duideliker beeld van hulle verbindinge - sowel sintakties as leksikaal.

3. Spesifiseer hulle beperkte leksikale verbindinge met die gekose werkwoorde.

4. Stel korrelasies vas tussen die waardes van die LF's en die semantiese kenmerke in die verkorte definisies van emosielekseme.

5. Onttrek herhalende waardes van LF's (en herhalende Bepalingspatrone) aan individuele leksikale inskrywings wat op hierdie korrelasies gebaseer is en lys hulle onder wat ons die generiese lekseem van die semantiese veld onder bespreking noem - in hierdie geval GEFÜHL 'emosie'. Dit lei enersyds na "verdigte" leksikale inskrywings vir emosielekseme, en andersyds na die skepping van 'n nuwe tipe leksikale inskrywing: die "algemene" inskrywing van 'n generiese lekseem.

Sleutelwoorde: LEKSIKOGRAFIE, LEKSIKON, DUITSE EMOSIELEKSEME, LEKSIKALE VERBINDINGE, KOLLOKASIES, TEORIE VAN BETEKENISTEKS, LEKSIKALE FUNKSIES, SEMANTIESE KENMERKE, SEMANTIES-LEKSIKALE KORRELASIES, INUIGTINGSONTTREKKING, ERFENIS, INDIVIDUELE LEKSIKALE SUBINSKRYWING, ALGEMENE LEKSIKALE SUBINSKRYWING.

\section{Introduction}

\subsection{The Statement of the Problem}

The present paper deals with a well-known problem of lexicon construction: How to represent lexical information within a linguistic description in a more compact and efficient way? More specifically, we are concerned with the problem of a more compact and efficient representation of restricted lexical co-occurrence information. ${ }^{1}$

Restricted lexical co-occurrence is the co-occurrence of lexemes such that the choice of a lexeme $L_{1}$ for the expression of a given meaning is contingent on 
another lexeme $L_{2}$ to which this meaning is applied. The phrase $L_{1}+L_{2}$ is called a collocation (cf. Firth 1957; Hausmann 1985; Benson 1989), of which $L_{2}$ is the base and $\mathrm{L}_{1}$, the collocate. Thus, in the collocations [to] do <"make> a FAVOR vs. [to] make $<{ }^{*} d 0>a$ MISTAKE the nouns are bases and the verbs, collocates.

Restricted lexical co-occurrence is an extremely wide-spread phenomenon, which needs to be captured in lexica for both human and computational use. Cf., for example, a few sentences chosen randomly from a newspaper (the collocates are italicized, the bases are written in small capitals):

(1) a. The President imposed an overnight CURFEW on three areas ... in order to stamp out $<=$ put down $>$ the VIOLENCE.

b. The panel issued a REPORT to the Secretary of State.

c. Reagan rejected PLEAS to open TALKS with striking US air controllers.

d. The heaviest PRISON TERMS in Kentucky history have been handed down against two men.

e. South African troops have spread a DRAGNET across the country in a SEARCH for three heavily ARMED black guerillas. The ANC has claimed RESPONSIBILTYY for the ATTACK launched last Tuesday in which four ROCKETS were fired at an army camp.

A method for a systematic description of restricted lexical co-occurrence, i.e. of collocations, in lexica has been introduced into linguistic theory under the heading of Lexical Functions (LFs) as early as 1966, see (Žolkovskij and Mel'čuk 1966) (for a short discussion of LFs, see 2.3). In terms of LFs, the collocation $L_{1}+L_{2}$ (with $L_{1}$ being the collocate and $L_{2}$ the base) is presented as $f\left(L_{2}\right)=L_{1}$, where $L_{2}$ is called the keyword of the corresponding $L F$ and $L_{1}$ its value. The $L F$ itself represents a specific semantico-syntactic relation between $L_{1}$ and $L_{2}$.

In accordance with the arbitrariness of collocations, LF values are, by definition, arbitrary, i.e. they cannot be fully predicted from the meaning or grammatical properties of the keyword.

However, this arbitrariness does not preclude partial motivation. Thus, the values of an LF may correlate with the semantic class of its keyword. For instance, in French most nominal lexemes that denote emotional attitudes go with 'eprouver '[to] experience' ('eprouver un profond respect/ m'epris '[to] feel deep respect/ contempt', 'eprouver de la compassion '[to] feel compassion', etc.). Similarly, German 'attitudinal' lexemes ACHTUNG 'respect', HASS hatred', MITLEID 'compassion', etc. co-occur with entgegenbringen '[to] show' and aufkommen '[to] come up'. In English, [ to] issue combines not only with report but also with STATEMENT, COMMENT, ORDER, etc.; [to] reject goes with plea as well as with PROPOSAL, ADVICE, SUPPOSITION, OFFER, and so on. ${ }^{2}$

All these examples show a correlation between the meaning of a lexeme and its restricted lexical co-occurrence: lexemes with common restricted lexical cooccurrence also share semantic features. This phenomenon is quite frequent in language; therefore, it must be possible - at least to some useful extent - to generalize restricted lexical co-occurrence instantiations along semantic lines. Such 
a generalization allows for a compact representation of information without an overhead of information multiplication in that it makes use of object classes: common semantic properties of several linguistic objects are extracted and specified only once as distinguishing properties of a specific object class; all objects which share these properties are defined as members of this class. That is, generalization implies a hierarchical representation with a partial order induced by the relation 'is more general than' between classes and their members, which can in their turn be again (more specific) classes. If $c_{2}$ is a subclass of $c_{1}$ (i.e. $c_{1} \supset$ $\left.C_{2}\right), C_{2}$ is characterized by all properties of $C_{1}$. Formally speaking, $C_{2}$ inherits the properties of $C_{1}$ along the " $C$ ", or "IS-A", link.

Here, we focus on the principle of inheritance as applied to the representation of lexicographic information - the lexical inheritance. Extensive use of this principle has already been made with respect to the inheritance of semantic and syntactic properties of lexemes.

Semantic Inheritance is based on semantic classification of lexemes. Thus, specific lexemes such as, e.g., CAT, DOG, and HORSE, are grouped into a class of ANIMALS; the common semantic features are then extracted from their descriptions to be associated with the class animal. This paradigm has been used, for example, in Nirenburg and Raskin's Conceptual Lexicon (Nirenburg and Raskin 1987), in Pustejovsky's Generative Lexicon (Pustejovsky 1991), in WordNet (Miller et al. 1993), etc.

For Syntactic Inheritance, lexemes that possess identical properties (semantic and / or syntactic) are grouped into classes such that the syntactic characteristics of those classes are formulated directly for each class. Then, for example, instead of describing the syntactic behavior of the lexeme [to] TRY individually, it is indicated that [to] TRY belongs to a particular class of verbs whose syntactic properties are stated for the class as a whole. This approach is typical of traditional linguistics and lexicography; it has recently also been applied in various formal grammatical models, such as Head Driven Phrase Structure Grammar (Pollard and Sag 1987, 1992). Word Grammar (Hudson and Fraser 1992) and linguistic representation formalisms (cf., for example, (Zajac 1992; Carpenter 1992) as well as in research aimed at predicting syntactic behavior from common semantic content (cf. e.g., the MIT Lexicon Project Hale and Keyser 1986; Levin 1989, 1993). ${ }^{3}$

The inheritance of lexical co-occurrence properties (henceforth Co-occurrence Inheritance) could be implemented using the same methodology: by grouping into one class all the lexemes that have identical values of the same LFs. However, such a "pure" classification does not apply well to restricted lexical co-occurrence. On the one hand, semantic and syntactic inheritance deals mainly with disjointed classes organized into a rigid hierarchized structure; the co-occurrence inheritance, on the contrary, gives rise to heavily overlapping classes which do not form a clear hierarchy. ${ }^{4}$ On the other hand, classes obtained in semantic and syntactic inheritance are "natural" in that for each of them a semantics- or syntax-based justification is available; in co-occurrence inheritance, the result would be "dummy" classes, which are not "natural" (the language has no lexemes to name them; there is no semantic or syntactic justification; different collocates 
would lead to intersecting classes; etc.).

Therefore, instead of aiming at a "pure" classification of lexemes based on their co-occurrence properties we take a different course: finding correlations between values of LFs and semantic features of the keywords. These correlations underlie a technique (discussed in Section 4) which allows for a significant generalization of restricted lexical co-occurrence presentation in a lexicon.

The essence of our work can be summed up in the following three points:

- devising a semantic description for lexemes under consideration - such that it would facilitate the determination of correlations with the values of LFs;

- finding and formulating the correlations themselves;

- exploiting these correlations in order to generalize lexical co-occurrence information.

\subsection{The Theoretical Framework and the Data}

The theoretical framework for this study is the Meaning-Text Theory (MTT) (Mel'cuk 1974, 1981, 1988) and, more specifically, the lexicographic part of MTT - the Explanatory Combinatorial Dictionary (ECD) (Mel'čuk and Zolkovskij 1984; Mel'čuk et al. 1984, 1988, 1992).

Our data domain is the semantic field of emotions in German, i.e. German lexemes such as ANGST 'fear', ÄRGER 'anger', BEGEISTERUNG 'enthusiasm', FREUDE 'joy', MITLEID 'compassion', etc. We have chosen emotion lexemes as test data for two reasons: First, emotion lexemes are linguistically very vivid. They are frequent, semantically complex, highly idiomatic, and, as a rule, exhibit a rich restricted lexical co-occurrence. Second, emotion lexemes have for a long time been in the focus of attention of linguistics and psychology; they have also been subject of extensive work in MTT (see, e.g., Iordanskaja 1970, 1972, 1973; Iordanskaja and Mel'čuk 1991).

We have chosen German because it is close enough to English but at the same time different enough to provide interesting insights. Besides, it is the mother tongue of one of the authors, which is crucial to the study of fine-grained semantics and lexical co-occurrence.

From the semantic field of emotions, we have selected the forty most frequent emotion nouns (listed in Appendix B, Section 1.1). These nouns are taken as keywords of ten verbal LFs (see Appendix A, Section 1), which are most frequently applied to emotion lexemes; from the verbs that appear as their values (LF-verbs), twenty-five have been selected for the present study (see Appendix B, Section 1.2). Thus, we analyze a $40 \times 25$ matrix representing all of the "emotion noun - LF verb" combinations (see Section 3.3). Obviously, this is merely a partial study; an exhaustive analysis would require the coverage of all emotion noun lexemes and all their collocate verbs, but such an effort goes far beyond the scope of our work. 


\subsection{The Methodology}

For the chosen forty lexemes, we proceed as follows:

1. Construct approximate descriptions of their meaning, i.e. what we will call the abridged lexicographic definitions; formulated in terms of semantic features, these definitions are supposed to provide as much semantic information as necessary for establishing correlations between the semantic features of a lexeme and its collocates. For example: ${ }^{5}$

Angst von $X$ vor $Y$ wegen $Z$ ' $X$ 's fear of $Y$ because of $Z^{\prime}=X^{\prime} s$ negative, manifestable, reactive, active, excited-state, self-control-loss-inflicting, permanent or temporary Gefühl directed at $Y$ because of $Z$

2. Specify their syntactic Government Patterns (a sample Government Pattern is given in Subsection 2.2), which are needed for a clearer picture of their cooccurrence - syntactic as well as lexical.

3. Specify their restricted lexical co-occurrence with the verbs chosen, i. e. the collocations of the type Angst haben lit. '[to] have fear' (but not "Bedauern haben lit. '[to] have regret'), in Wut geraten lit. '[to] get into rage' = '[to] begin to be in rage' (but not "in Haß geraten lit. '[to] get into hatred' = '[to] begin to be in hatred'), etc. This is to be done in terms of LFs; for example, Oper $_{1}$ (ANCST) $=$ haben, IncepOper $_{1}$ (WUT) = geraten, etc. (The definitions of relevant LFs are found in Appendix A, Section 1.)

4. Establish correlations between the values of LFs and the semantic features in the abridged definitions of the emotion lexemes. For example: if the value of Oper $_{1}$ of a lexeme is entgegenbringen lit. '[to] show', then the abridged definition contains the semantic feature 'attitudinal', see above.

5. Based on these correlations, extract recurrent values of LFs (and recurrent Government Patterns) from individual lexical entries and list them under what we call the generic lexeme of the semantic field under study - in this case, GEFÜHL 'emotion'. This leads on the one hand, to "compressed" lexical entries for emotion lexemes (all the forty of them are given in full in Appendix (); and on the other hand, to the creation of a lexical entry of a new type: the "public" entry of a generic lexeme, see Subsection 4.5.

The treatment of lexical data as outlined above shows that significant correlations between restricted lexical co-occurrence and semantic features exist; and they allow for reasonable generalizations. At the same time, the correlations are far from absolute: idiosyncrasies in collocations abound and have to be simply listed. 


\subsection{The Structure of the Paper}

The structure of the paper follows directly from our methodology. First, we need a brief characterization of our formal framework: the Explanatory Combinatorial Dictionary (Section 2). Second, we provide an overview of the lexicographic data on emotion lexemes in German: discussion of their semantics, syntax, and restricted lexical co-occurrence (Section 3). Third, we address the central problem of this study: a more efficient representation of lexical co-occurrence (Section 4). Section 4 is divided into five parts: finding correlations between restricted lexical co-occurrence and meaning, which is a prerequisite for co-occurrence inheritance (4.1); formulating our proposal for the description of syntactic and lexical cooccurrence inheritance (4.3); illustrating the proposal by some concrete data: sample entries for emotion lexemes and the entry for the generic lexeme of the field (4.4 and 4.5). Finally, we discuss the results obtained, some open problems and the future work in the domain of co-occurrence inheritance (Section 12).

The paper also includes three appendices: Appendix A provides the definitions of LFs we need for our exposition; Appendix B contains the data on emotion lexemes and their collocates; Appendix C contains the ECD-type compressed lexical entries for all forty German emotion lexemes studied (i.e. entries compiled using inheritance techniques proposed).

\section{The Framework: Explanatory Combinatorial Dictionary (ECD)}

The present study is substantive and does not depend on a specific theoretical framework: the correlations between lexical co-occurrence and meaning can be stated within any theory which offers sufficient formal means for their systematic treatment. However, to be able to present a concrete proposal, we need a concrete formalism. The formalism we have chosen is that of the Meaning-Text Theory.

It is impossible to state in this paper the general postulates, main principles and the formal apparatus advanced in MTT, so we will rely on the references given above. However, we will say a few words about the structure of a lexical entry in the ECD, since the problem addressed lies within its realm and the solution proposed is intimately linked to the form of its entries.

In an ECD, a distinct lexical entry is defined for each lexeme $\mathrm{L}_{;}^{6} \mathrm{~L}$ is the head lexeme of this entry. Here we will touch briefly only on the three major ECD entry zones, which are relevant to our purpose:

- the Semantic Zone, which contains the Definition of the head lexeme;

- the Syntactic Zone, which contains its Government Pattern;

- the Lexical Co-occurrence Zone, which contains the Values of LFs applicable to the head lexeme.

The Semantic Zone and the Lexical Co-occurrence Zone are our main concern; the Syntactic Zone provides the necessary bridge between the two, the Government 
Pattem being essentially involved both in the definition and in the specification of the $L F$ values.

\subsection{Semantic Zone}

The definition of a predicate head lexeme $L^{7}$ consists of a propositional form, which makes explicit the semantic actants $\left(\operatorname{Sem} A(L)^{8}\right.$ of $\left.L\right)$ designated $X, Y, Z, \ldots$, and the definition proper, i.e. a semantic decomposition of L's meaning, which specifies the properties of L's SemAs and the relationships between them. The following example shows the definition of one sense of the verb [to] HELP [consider. Martin helped us to write this paper with his advice]:

$X$ helps $Y$ to $Z$ with $W=' Y$ trying to do or doing $Z, X$ uses $X$ 's resources $W$, adding $W$ to $Y$ 's efforts such that $W$ cause that doing $\mathrm{Z}$ becomes possible or easier for $\mathrm{Y}^{\prime}$

The genuine, full-fledged definitions of emotion lexemes are constructed in the same way, see Subsection 3.1.

\subsection{Syntactic Zone}

The Government Pattern (GP) of L specifies the correspondence between L's semantic and syntactic actants (notated as I, II, ...) $)^{9}$ and the expression of its syntactic actants on the surface. The GP is represented as a table with $m$ columns and $n$ rows, where $m$ is the number of SemAs of $L$ and $n$ the maximum number of different surface means for the expression of a syntactic actant. Consider the GP for the verb [to] HELP in the above sense ( $X$ helps $Y$ to $Z$ with $W$ ):

\begin{tabular}{|l|l|l|l|}
\hline $\mathrm{X}=\mathrm{I}$ & $\mathrm{Y}=\mathrm{II}$ & $\mathrm{Z}=\mathrm{III}$ & $\mathrm{W}=\mathrm{IV}$ \\
\hline $1 . \mathrm{N}$ & $1 . \mathrm{N}$ & $\begin{array}{l}\text { 1. } \mathrm{V}_{\text {inf }} \\
\text { 2. to } \mathrm{V}_{\text {inf }}\end{array}$ & $\begin{array}{l}\text { 1. with } \mathrm{N} \\
\text { 3. by by } \mathrm{V}_{\text {ger }} \\
\end{array}$ \\
& & $\begin{array}{l}\text { 4. } \mathrm{PREP}_{\text {dir }} \mathrm{N} \\
\end{array}$ & \\
\hline
\end{tabular}

This GP covers, e.g., such expressions as:

Leo helped Igor prepare the dinner by peeling the potatoes.

The warden helped Houdini to escape with his advice.

John helped me with a generous gift of money.

The man helped Tony up the stairs by pushing him.

Mary helped with her advice. 
(We do not quote here constraints on mutual co-occurrence of different realizations of syntactic actants.)

\subsection{Lexical Co-occurrence Zone}

One of the major novelties of the ECD is the emphasis on the systematic coverage of restricted lexical co-occurrence. As has already been stated, an ECD describes lexical co-occurrence by means of Lexical Functions (LFs).

An LF $f$ is a dependency that associates with a lexical unit (i.e. a lexeme or a phraseme) $L$, called the keyword of $f$, a set of (quasi-)synonymous lexical expressions $\left\{L_{i}\right\}$, called the value of $f_{;}$an $L_{i}$ expresses - with respect to $L-$ an abstract meaning which corresponds to $f$. In what follows, we consider only LFs whose keywords and values are lexemes.

There are two major types of LFs: standard and non-standard ones, the difference between them being purely quantitative: standard LFs have numerous keywords and numerous values. (For more on LFs see, e.g., Mel'čuk, forthcoming; Mel'čuk and Žolkovskij 1984.)

Standard LFs include an empirically established subset of about sixty LFs that are frequent enough and particularly convenient for describing restricted lexical co-occurrence. These are called simple standard LFs, each of them being identified by an individual name.

The following two examples illustrate the concept of the simple standard LF:

1. Magn: provides for its keyword (which is a lexeme with a scalable meaning), an adjectival or adverbial phrase that expresses the meaning 'intense(ly)'. Examples of Magn for nouns meaning 'fear' are:

$\begin{array}{lll}\text { Eng. } & \text { Magn(fear }) & \text { = grave, mortal } \\ \text { Fr. } & \text { Magn(peur }) & =\text { immense 'immense', bleue 'blue' } \\ \text { Germ. } & \text { Magn(Angst) } & =\text { wahnsinnige 'crazy', Todes- 'mortal' } \\ \text { Rus. } & \text { Magn(strax) } & =\text { dikij 'wild', žutkij 'eery' }\end{array}$

2. Oper 1 : provides for its keyword (which is a predicate noun) $\mathrm{N}$ a semantically empty (or contextually emptied) verb which takes as its grammatical subject the name of the first actant of $\mathrm{N}$, i.e. the agent of the action, the undergoer of the event, the subject of the state, etc., and as its direct (or, more precisely, its main) object, the lexeme $N$ itself.

Examples of Oper ${ }_{1}$ for nouns meaning 'complaint' are:

$\begin{array}{lll}\text { Eng. } & \text { Oper }_{1} \text { (complaint) } & =[\text { to }] \text { lodge }[\mathrm{DET} \sim] \\ \text { Fr. } & \text { Oper }_{1} \text { (plainte) } & =\text { porter }[\sim]]^{\prime}[\text { to }] \text { carry' } \\ \text { Germ. } & \text { Oper }_{1}(\text { Beschwerde }) & =\left[\text { DET } \sim \sim_{a c c}\right] \text { oorbringen '[to] bring up' } \\ \text { Rus. } & \text { Oper }_{1}(\text { žaloba }) & =\text { podat }^{\prime}[\sim u]^{\prime}[\text { to }] \text { hand in' }\end{array}$


The expression in brackets is the Government Pattern of the LF verb in question: ' $\sim$ ' replaces the keyword; and DET indicates that the noun takes the determination according to general rules of the language.

Besides simple standard LFs, complex standard LFS and configurations of LFs are distinguished.

A complex standard $L F$ is a combination of several syntactically related simple standard LFS that has a single lexical expression covering the meaning of the combination as a whole.

Examples of complex LFs for nouns meaning 'fear' (for the simple standard LFs the complex LFs in these examples are composed of, see Appendix A) are:

$\begin{array}{lll}\text { Eng. } & \text { CausFunc }_{1}(\text { fear }) & =[\text { to }] \text { arouse, kindle }[\sim \text { in } N] \\ \text { Fr. } & \left.\text { AntiVer }_{1} \text { (peur }\right) & =\text { injustifiée 'unjustified' } \\ \text { Germ. } & \text { Liqu }_{1} \text { Func }_{0}(\text { Angst }) & =[\mathrm{DET} \sim \text { acc }] \text { überwinden } \\ \text { ' } & \text { too } \text { overcome' }^{\prime} \\ \text { Rus. } & \text { PredAntiAble }(\text { strax }) & =\text { ne znat' }[\sim a] \text { 'not to know' }\end{array}$

A configuration of LFs is a combination of several syntactically unrelated LFs applied to the same keyword that has one single lexical expression covering the meaning of the combination as a whole. In a configuration of LFs, the ' + ' sign is used to separate the constituents.

Examples of LF configurations are:

\begin{tabular}{|c|c|c|}
\hline $\begin{array}{l}\text { Eng. } \\
\text { Fr. }\end{array}$ & $\begin{array}{l}\text { Magn + Oper }{ }_{1} \text { (laughter) } \\
\text { Plus + IncepOper } 1 \text { (vitesse 'speed') }\end{array}$ & $\begin{array}{l}=\text { roar }[\text { with } \sim] \\
=\text { prendre }[\text { de la } \sim] \\
\text { [to] pick up' }\end{array}$ \\
\hline Germ. & Magn + IncepOper ${ }_{1}$ (Begeisterung & $\begin{array}{l}\text { 'excitement') } \\
=[\text { in } \sim \text { acc }] \text { ausbrechen } \\
\text { [to] break out' }\end{array}$ \\
\hline us. & Magn + Oper 1 (otčajanie 'despair') & $\begin{array}{l}=\text { byt' [vo vlasti } \sim j a] \\
\text { [to] be at the mercy of }\end{array}$ \\
\hline
\end{tabular}

A complete list of LFs used in this paper is given in Appendix A.

\section{Emotion Lexemes in German}

Applying the formal framework presented above to the raw data on German emotion lexemes, we obtain ECD-type lexical entries for the corresponding semantic field. These entries have been established by accounting for the speakers' semantic intuition, the data of existing dictionaries as well as text corpora (see below), and the results of several linguistic and psychological studies on the semantics of emotion lexemes.

These entries constitute the base for formulating our lexical co-occurrence inheritance proposal. Although the elaboration of lexical entries is an extremely 
important task in itself, explaining the details and justifying our decisions is not the subject of our paper; we take these entries as given.

\title{
3.1 Semantics of Emotion Lexemes in German
}

Our semantic description of emotion lexemes draws heavily on the research in lexical semantics and lexicography (see, in particular, Iordanskaja 1970, 1972, 1973; Wierzbicka 1972, 1986, 1992; Apresjan and Apresjan 1993; Bergenholtz 1980; Mel'čuk et al. 1984; lordanskaja and Mel'čuk 1991). The other important source of our inspiration are studies of emotions in psychology, which deal in the first place with their cognitive model (see, e.g., Averill 1975; Dahl and Stengel 1978; Russel 1980; Ortony et al. 1988; Oatley and Johnson-Laird 1987). Unlike psychologists, however, we are interested in the linguistic meaning of emotion lexemes, not in a cognitive model of emotions themselves. Nonetheless, the psychologists' findings concerning basic commonalities and differences between emotions carry over to the meanings of emotion lexemes (Ortony et al. 1987; Johnson-Laird and Oatley 1989). Hence, psychological research in the field of emotions is highly relevant to our endeavor and is taken into account while formulating the definitions of emotion lexemes.

Based on the information available, we obtain - within the framework of the $\mathrm{ECD}$ - definitions for emotion lexemes such as the one shown below:

\begin{abstract}
Achtung von $X$ vor $Y$ wegen $Z$ 'respect of $X$ for $Y$ because of $Z$ ' $=$ an unexcited emotion of $X$ towards $Y$ caused by $X$ 's favorable attitude towards $Y$; this attitude is caused by $X$ 's believing that $Y$ 's actions, state, or properties $Z$ cause that $Y$ has a high moral or social value and that, consequently, $X$ has to take $Y$ into consideration; this causes that $X$ tends to take $Y$ into consideration in X's behavior; this emotion is such that people normally have in similar situations.
\end{abstract}

Quite appropriate for the semantic characterization of emotion lexemes (e.g., with respect to lexical choice and semantic combinability), the definitions of this type prove, however, unsuitable for finding and stating correlations between lexical cooccurrence and meaning. They are very complex, not standard enough, and do not allow for an easy access to the relevant semantic components. Thus, the permanent character of achtung 'respect', which turns out to be important for correlating lexical co-occurrence with meaning, is not explicitly present in the definition: it is "hidden" within the meaning of 'attitude'. In order to overcome this difficulty, we propose the use of semantic dimensions. 


\subsubsection{The Notion of Semantic Dimension}

In this paper, a semantic dimension is a set of two or three mutually exclusive values; as a general rule, all but one of these values are "marked". A marked value of a dimension $n$ is a label which stands for a component of the corresponding definition. The unmarked value of $n$ means that this dimension is irrelevant to the definition in question; we will call it "n-neutral". Some dimensions (see, e.g., PERMANENCE, below) have only marked values.

For German emotion lexemes we propose eleven semantic dimensions with the following values:

\begin{tabular}{|c|c|}
\hline $\begin{array}{l}1 \text { intensity } \\
2 \text { polarity } \\
3 \text { manifestability }\end{array}$ & $\begin{aligned}= & \{\text { 'intense', 'moderate', 'intensity-neutral' }\} \\
= & \{\text { 'pleasant', 'unpleasant', 'polarity-neutral' }\} \\
= & \{\text { 'manifested', 'tending-to-be- } \\
& \text { manifested','manifestation-neutral' }\}\end{aligned}$ \\
\hline $4 \mathrm{di}$ & ed', 'direction-neutral'\} \\
\hline & $\{$ 'm \\
\hline $6 r$ & \{'reactive', 'reactivity-neutra \\
\hline 7 a & \{'attitudinal', 'attitude-neut \\
\hline 8 a & $=\{$ 'active', 'activity-neutral' $\}$ \\
\hline $\begin{array}{l}9 \text { excitation } \\
10 \text { self-contr }\end{array}$ & $\begin{array}{l}=\{\text { 'excited-state', 'excitation-neutral' }\} \\
=\{\text { 'self-control-loss-inflicting', 'self-control-neu }\end{array}$ \\
\hline 1 permanenc & permanent' \\
\hline
\end{tabular}

In psychology, for the description of the meaning of emotions and emotion lexemes, a multidimensional scaling with similar dimensions has often been used. Thus, 'pleasantness' and 'arousal' (corresponding to our POLARTTY and EXCITATION dimensions) are central in Russel's Circumplex Model of Affect (Russel 1980); the 'mentality' of an emotion is essential to Ortony (et al. 1987)'s "cognitive conditions", etc. ${ }^{10}$

There are substantial implications between the values of the dimensions listed above. For instance, an 'attitudinal' emotion is necessarily 'directed' at something and 'permanent'. However, we have not studied these implications as yet, and, therefore, do not consider them systematically in what follows.

The eleven dimensions have been arrived at by analyzing the definitions of German emotion lexemes. These dimensions can be represented in the familiar form of semantic features; thus, in Figure 1, we give a complete matrix of semantic features for our forty lexemes, using " + " for the first marked value, "-" for its opposite, i.e. the second marked value (where it is present), and a blank for an nneutral (unmarked) value. ${ }^{11}$ In one case (the dimension PERMANENCE), "+" and "I" are used together - to indicate that the definition of the lexeme in question includes a disjunction of both labels. However, for reasons of a better readability, instead of "+", "-", etc., we use linear sequences of conventional labels in which the "n-neutral" values are omitted (see above). One such sequence is the "definitorial" part of what we call the abridged definition of a lexeme. An 
abridged definition contains a propositional form (the same as in the full definition) and - instead of the semantic decomposition that fully specifies the meaning of the lexeme - the corresponding sequence of semantic feature values. For example, the abridged definition of ACHTUNG 'respect' appears as follows:

Achtung von $X$ vor $Y$ ' $X$ 's respect towards $Y^{\prime}=X^{\prime}$ 's pleasant, mental, attitudinal, active, permanent Gefühl directed at $Y$

The label 'pleasant' stands for one of the "real" semantic components ' $X$ feels good', ' $X$ has a favorable attitude', etc.; the label 'mental' stands for '...X's believing that ...'; and the label 'active' reflects the component '...X tends ... in X's behavior'. The other labels are to be interpreted literally.

Let it be emphasized that an abridged definition does not supply any new information; it is redundant with respect to the full definition. But it presents the information that is necessary for our specific task in an explicit, standard and compact form, which significantly facilitates the finding of correlations between lexical co-occurrence and meaning of emotion lexemes, as well as formulating the semantic conditions on lexical co-occurrence. ${ }^{12}$ See Figure 1 on next page.

\subsubsection{List of Semantic Dimensions of Emotion Lexemes}

For each dimension $n$, we give in Appendix B, Section an enumeration of lexemes whose abridged definitions contain one of its marked values, illustrative examples and additional comments; $n$-neutral lexemes are not explicitly listed. The label " $n$ neutral" is used by default. Here we discuss the dimensions themselves.

\section{Intensity: 'intense' $\left({ }^{\prime}+\right)$ vs. 'moderate' $\left({ }^{\prime}-1\right)$ vs. 'intensity-neutral'}

The labels 'intense'/ 'moderate' characterize emotion lexemes whose full-fledged definitions describe intense or moderate emotions. An 'intense' lexeme $\mathrm{L}$ denotes an inherently intense emotion. The main characteristics of an 'intense' emotion lexeme is that if the emotion denoted is below a certain level of intensity, $\mathrm{L}$ is not appropriate any more. The inverse is true for 'moderate' lexemes: if the emotion denoted is above a certain level of intensity, a 'moderate' lexeme $L$ is not appropriate. Thus, the 'intense' lexeme STAUNEN 'astonishment' cannot denote a very weak astonishment: the moderate VERWUNDERUNG 'amazement' is preferred instead (and vice versa: to express a very strong astonishment STAUNEN rather than VERWUNDERUNG should be used). ${ }^{13}$

Examples of 'intense' lexemes include BEGEISTERUNG 'excitement', HASS 'hatred', ZORN 'wrath'.

Examples of 'moderate' lexemes are: VERÄRGERUNG 'annoyance', VERDRUSS 'vexation', and VERWUNDERUNG 'amazement'.

Examples of 'intensity-neutral' lexemes are: ANGST 'fear', FREUDE 'joy', SCHAM 'shame'. 
Figure 1: Semantic dimensions of emotion lexemes in German

\begin{tabular}{|c|c|c|c|c|c|c|c|c|c|c|c|}
\hline $\begin{array}{l}\text { Key } \\
\text { Lexeme }\end{array}$ & $\begin{array}{l}\text { 量 } \\
\text { 量 }\end{array}$ & $\frac{\overrightarrow{6}}{8}$ & 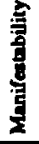 & 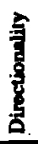 & $\begin{array}{l}\text { 总 } \\
\frac{8}{2}\end{array}$ & 疍 & $\begin{array}{l}\text { 를 } \\
\text { 㿣 } \\
\text { 量 }\end{array}$ & 总 & $\begin{array}{l}\text { 量 } \\
\frac{\mathrm{g}}{9} \\
\mathrm{~g}\end{array}$ & $\begin{array}{l}\overline{8} \\
\stackrel{5}{8} \\
\overline{3}\end{array}$ & $\begin{array}{l}8 \\
8 \\
8 \\
8\end{array}$ \\
\hline ACHTUNG "reapect" & & + & $\cdot$ & + & + & & + & + & & & + \\
\hline ANGST 'rear' & & - & - & + & & + & & + & + & + & \pm \\
\hline$\overline{A R G E R}$ 'enger' & & - & - & + & & + & & & + & & - \\
\hline AUFREGUNG 'excitemen' & & $\cdot$ & + & & & & & & + & & $\cdot$ \\
\hline BEDAUERN 'regrot' & & $\cdot$ & & & + & & & & & & 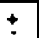 \\
\hline BEGEISTERUNG 'onthusinm" & + & + & + & & & & & + & + & + & - \\
\hline EIFERSUCHT 'jenlony' & & $\cdot$ & - & + & & + & & & + & + & + \\
\hline EKEL 'disguet' & & $\cdot$ & $\cdot$ & + & & + & & + & & & 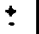 \\
\hline EMPOORUNG 'indignation" & + & - & - & + & + & + & & & + & & - \\
\hline ENTSETZEN 'barro' & + & - & + & & + & + & & + & + & + & - \\
\hline ENTTÄUSCHUNG 'dieappointment' & & - & & & & + & & & & & - \\
\hline ENTZOCKEN "delight" & + & + & + & + & + & + & & & + & & - \\
\hline ERREGUNG 'agitation" & & & - & & & & & & + & & $\cdot$ \\
\hline FREUDE 'joy" & & + & + & & & + & & + & + & + & \pm \\
\hline FURCHT 'frigbt' & & - & & + & + & + & & + & + & & + \\
\hline GROLL 'grudge' & & - & . & + & + & + & & & & & \pm \\
\hline HASS 'batred" & + & - & - & + & + & & + & + & & + & + \\
\hline HOFFNUNG "bope" & & + & & & + & & & & & & + \\
\hline LEDENSCHAFT 'PaAcioo" & + & + & - & + & & & & + & + & + & + \\
\hline LIEBE 'bve" & + & + & - & + & & & + & & + & & + \\
\hline MTTLED' 'Comparion' & & - & & + & + & & + & + & & & + \\
\hline NEID 'oovy' & & - & & + & & & & & & & + \\
\hline PANIK 'panic' & + & - & + & & & + & & + & + & + & - \\
\hline REUE' repentance' & & - & - & & + & & & & & & \pm \\
\hline ROHRUNG "being wouched "moved" & & + & $\cdot$ & & + & + & & + & + & & $\cdot$ \\
\hline SCHADENFREUDE 'malicious joy' & & + & & + & + & & & & + & & - \\
\hline SCHAM 'mame' & & - & $\cdot$ & & + & + & & + & & & $\rightleftarrows$ \\
\hline SCHEU 'abynese' & & $\cdot$ & + & & & & & + & & & 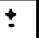 \\
\hline SCHRECK "mror" & + & - & - & & & + & & + & + & + & - \\
\hline STAUNEN 'atoaichment' & + & & + & & + & + & & & & & - \\
\hline TRAUER 'morov' & & $\cdot$ & - & & & & & & & & + \\
\hline VERACHTUNG 'contempe' & & - & & + & + & & + & + & & & + \\
\hline VERARGERUNG 'mmyence" & - & $\cdot$ & $\cdot$ & + & + & + & & & + & & - \\
\hline VERDRUSS 'varetion' & $\cdot$ & - & - & & + & + & & & + & & - \\
\hline VERI EGENHFIT "ambarmetument" & & - & $\cdot$ & & + & & & + & & & - \\
\hline VERWUNDERUNG 'menement' & - & & - & & + & & & & & & - \\
\hline VERZWEIFLUNG 'diepeir' & + & $\dot{-}$ & + & & + & + & & + & + & + & - \\
\hline WUT 'mge' & + & - & + & + & & + & & + & + & + & - \\
\hline ZORN 'Writh' & + & $\cdot$ & + & + & + & + & & + & + & + & - \\
\hline ZUNEIGUNG 'affection' & & + & & + & + & & + & + & & & + \\
\hline
\end{tabular}


'Intense' lexemes tend not to co-occur, with such "mitigators" as leicht 'light", gering 'slight', and schwach 'weak'. For reasons of symmetry, one would expect that 'moderate' lexemes do not co-occur with "intensifiers" such as groß 'big', stark 'strong', and riesig 'huge', but they do. With a 'moderate' lexeme an intensifier expresses, however, a limited intensity: große Verärgerung does not reach the intensity of WUT (cf. 'rasende Verärgerung 'terrible annoyance' but rasende Wut 'terrible rage'). 'Intensity-neutral' lexemes freely admit mitigators as well as intensifiers.

\section{Polarity: 'pleasant' $\left({ }^{\prime}+\right.$ ') vs. 'unpleasant' $\left({ }^{\prime}-\right.$ ') vs. 'polarity-neutral'}

As has already been mentioned above, the label 'pleasant' characterizes emotion lexemes whose full-fledged definitions contain one of the semantic components ' $X$ feels good', ' $X$ has a favorable attitude', ' $X$ is pleased', etc. Examples of 'pleasant' emotion lexemes are: FREUDE 'joy', HOFFNUNG 'hope', SCHADENFREUDE 'malicious joy'.

Emotion lexemes whose definitions describe unpleasant emotions (" $X$ feels displeased") are characterized by the label 'unpleasant' (e.g., ÄRGER 'anger', HASS 'hatred', MITLEID 'compassion').

Three emotion lexemes (STAUNEN 'astonishment', VERWUNDERUNG 'amazement', and ERREGUNG 'agitation') cannot be characterized as being either 'pleasant' or 'unpleasant'; these lexemes are 'polarity-neutral'.

For further discussion of this dimension, see Appendix B, Section 2.

3. Manifestability: 'manifested' ('+') vs. 'tending-to-be-manifested' ('-') vs. 'manifestation-neutral'

The label 'manifested' characterizes emotion lexemes whose full-fledged definitions contain a mention of the obligatory manifestation of the emotion denoted: '...is manifested as ...' (cf. Sommerfeldt and Schreiber 1983); thus PANIK 'panic' cannot be defined without specifying the observable behavior of people in panic: if this manifestation is absent, the lexeme panic is not appropriate. An emotion lexeme is characterized by the label 'tending-to-be-manifested' if its definition includes the component '...tends to be manifested as ...'; thus the definition of EKEL 'disgust' includes the mention of possible specific gestures and facial expressions of a disgusted person, although this lexeme is still appropriate to denote this emotion even in the absence of such a manifestation. A 'manifestation-neutral' lexeme does not contain an explicit mention of manifestation. This is not because the corresponding emotion cannot be manifested, rather this is because no one of its manifestations are characteristic enough to be included into the definition.

Examples of 'manifested' lexemes are: BEGEISTERUNG 'enthusiasm', ENTZÜCKEN 'delight', wUT 'rage'.

Examples of 'tending-to-be-manifested' lexemes include: ANGST 'fear', ERREGUNG 'agitation', SCHAM 'shame'. 
Examples of 'manifestation-neutral' lexemes include: EIFERSUCHT 'jealousy', HOFFNUNG 'hope', NEID 'envy'.

4. Directionality: 'directed' $($ ' + ') vs. 'directionality-neutral'

The label 'directed' characterizes emotion lexemes whose full-fledged definitions contain the semantic component '[emotion] directed at ...'. Such lexemes denote emotions whose source necessarily is at the same time their object: e.g., EIFERSUCHT 'jealousy', EMPÖRUNG 'indignation', GROLL 'grudge'. All other emotion lexemes are 'directionality-neutral' (e.g., AUFREGUNG 'excitement', FREUDE 'joy', VERDRUSS 'vexation').

\section{Mentality: 'mental' ('+') vs. 'mentality-neutral'}

The label 'mental' characterizes emotion lexemes whose full-fledged definitions contain a mention of mental activity such as 'believing', 'being certain', 'presupposing', etc. Therefore, a 'mental' emotion lexeme cannot naturally be used in reference to an animal or a very young child: they cannot experience 'mental' emotions.

Examples of 'mental' lexemes are: ACHTUNG 'respect', GROLL 'grudge', VERLEGENHEIT 'embarrassment'; examples of 'mentality-neutral' lexemes are: FREUDE 'joy', LIEBE 'love', wUT 'rage'.

Certain lexemes cannot easily be classified either as 'mental' or as 'mentalityneutral'. Especially the mental character of FURCHT 'fright' has controversially been discussed in numerous publications. Following, e.g., (Thiele 1965; Hoffmeister 1955) and others (and unlike, e.g., Bergenholtz 1980; Amold et al. 1980), we consider FURCHT to be 'mental'.

\section{Reactivity: 'reactive' ('+') vs. 'reactivity-neutral'}

The label 'reactive' characterizes emotion lexemes whose full-fledged definitions include the component 'an immediate reaction to $Y^{\prime}$ ' with $Y$ being a specific referential object or situation; the emotion denoted is an emotional event (i.e. is conceptualized as having a clear cut beginning and an end): e.g., ARGER 'anger', ENTZÜCKEN 'delight', PANIK 'panic'. Other emotions are emotional properties (predispositions with respect to generic non-referential objects or situations) or emotional states (conceptualized without clear-cut phases): e.g., ACHTUNG 'respect', HOFFNUNG 'hope', 'envy'; the lexemes that denote them are 'reactivityneutral'. Cf. the similar opposition between occurrent vs. dispositional emotions in Pitcher (1965).

\section{Attitudinality: 'attitudinal' ('+') vs. 'attitude-neutral'}

The label 'attitudinal' characterizes emotion lexemes whose full-fledged definitions contain the component 'caused by $X$ 's attitude towards $Y$ '. 'Attitudinals' 
include, e.g., ACHTUNG 'respect', HASS 'hatred', LIEBE 'love'; they are a subclass of 'directed' emotion lexemes. Among the attitude-neutral lexemes, we find FREUDE 'joy', PANIK 'panic', TRAUER 'sorrow', etc.

\section{Activity: 'active' ('+) vs. 'activity-neutral'}

The label 'active' characterizes emotion lexemes whose full-fledged definitions contain the component 'such that the emotion causes that $X$ [= the experiencer] tends to ...' ${ }^{14}$ Thus, the definition of achtung 'respect' contains '[attitude] causes that $X$ tends to take $Y$ into consideration in $X$ 's behavior'. Further 'active' emotion lexemes are, e.g., PANIK 'panic' and SCHAM 'shame'. Activity-neutral lexemes include ENTTÄUSCHUNG 'disappointment', REUE 'repentance', VERWUNDERUNG 'amazement'.

\section{Excitation: 'excited-state' ('+) vs. 'excitation-neutral'}

The label 'excited-state' characterizes emotion lexemes whose full-fledged definitions specify the corresponding emotions as 'an excited state of the psyche': e.g., ÄRGER 'anger', SCHRECK 'terror', zORN 'wrath'. Others are 'excitation-neutral': e.g., ACHTUNG 'respect', HOFFNUNG hope', SCHEU 'shyness'. There is a strong correlation between Excitation and Manifestability: all 'excitedstate' lexemes are - with the exception of FURCHT 'fright' and SCHADENFREUDE 'malicious joy' - 'manifested' or 'tending-to-be-manifested'; the inverse is not true (i.e., for example, EKEL 'disgust', GROLL 'grudge', SCHAM 'shame' are 'tending-tobe-manifested' but not 'excited-state').

\section{Self-control: 'self-control-loss-inflicting' ('t') vs. 'self-control-neutral'}

The label 'self-control-loss-inflicting' characterizes emotion lexemes whose fullfledged definitions specify the corresponding emotions as 'tending to inflict the loss of the self-control by the experiencer'; 'self-control-loss-inflicting' lexemes include, e.g., LEIDENSCHAFT 'passion', PANIK 'panic', WUT 'rage'. Otherwise an emotion lexeme is 'self-control-neutral': e.g., MITLEID 'compassion', TRAUER 'sorrow', ZUNEIGUNG 'affection'.

\section{Permanence: 'permanent' ('+') vs. 'temporary' ('-')}

The labels 'permanent'/ 'temporary' characterize emotion lexemes whose fullfledged definitions specify the corresponding emotions as 'a permanent/ temporary state of the psyche' (this specification can also be implicit, e.g., an 'attitude' is a 'permanent state of the psyche' and therefore an attitudinal is implicitly specified as permanent). Thus, ACHTUNG 'respect', NEID 'envy', and ZUNEIGUNG 'affection' are 'permanent'; ERREGUNG 'agitation', VERLEGENHETT 'embarrassment', and VERWUNDERUNG 'amazement' are 'temporary'. 
All 'attitudinals' are 'permanent' (cf. ACHTUNG and ZUNEIGUNG above); the inverse is not true: the 'permanent' lexemes NEID 'envy', HOFFNUNG 'hope', TRAUER 'sorrow' are not 'attitudinal'. Some emotion lexemes are considered to be both 'permanent' and 'temporary'; such are, e.g., ANGST 'fear', FREUDE 'joy', etc. This means that such a lexeme as angst is indiscriminately used to express permanent fears as well as a temporary fear, i.e. an emotional predisposition to 'being afraid of something' and a specific instance of 'being afraid of something' in a specific situation. Lexemes with this characteristics are supplied with both labels connected disjunctively (the full-fledged definition of such a lexeme necessarily includes a disjunction, cf. the definition of Rus. STRAX 'fear' in Iordanskaja and Mel'čuk 1991).

\subsection{Government Patterns of Emotion Lexemes in German}

Although this paper is aimed, first of all, at the problem of the inheritance of restricted lexical co-occurrence, we have to deal with the government patterns (GPs) of the lexemes concerned as well: the GP is intimately related both to the definition and to the LFS of the head lexeme.

Generally speaking, German emotion lexemes fall into two classes with respect to their semantic actants: those with two $(X$ and $Y)$ and those with three actants $(X, Y$, and $Z)$. The generic lexeme of the field - GEFÜHL - itself has four actants, see page 26).

First Actant. The first semantic actant $(x)$ is the Experiencer. The surface means used in German to express the corresponding syntactic actant I are identical for all the lexemes considered:

\begin{tabular}{|l|}
\hline $\mathrm{X}=\mathrm{I}$ \\
\hline 1. $\mathrm{N}_{\text {gen }}$ \\
2. von $\mathrm{N}_{\text {dat }}$ \\
3. Adj $_{\text {poss }}$ \\
\hline
\end{tabular}

1. Elkes Aufregung 'Elke's excitement'.

2. Aufregung von Elke 'excitement of Elke'

3. ihre Aufregung 'her excitement'

Second Actant. The second semantic actant $(Y)$ is the Source of the emotion or its Source which is simultaneously its Object. The surface means used to express the corresponding DSyntA II are rather heterogeneous: phrases with different prepositions such as auf, für, gegenüber, über, mit, and $z u$, as well as the subordinate conjunction daß (with or without an introductory prepositional pronoun: darüber [daß], etc.). In the example below, we show the realization of the second actant for ANGST 'fear': 


\begin{tabular}{|l|}
\hline $\mathrm{Y}=\mathrm{II}$ \\
\hline 1. vor $\mathrm{N}_{\text {dat }}$ \\
2. $z u \mathrm{~V}_{\text {inf }}$ \\
3. daß PROP \\
\hline
\end{tabular}

1. Angst vor dem Hund lit. 'fear of the dog'

2. Angst, die Straße zu überqueren lit. 'fear of crossing the street'

3. Angst, daß es regnet lit. 'fear that it will rain'

Third Actant. The third semantic actant $(\mathrm{z})$ is the immediate cause of the emotion. The surface means used to express the corresponding DSyntA III is identical for all the emotion lexemes which have it; it is the prepositional phrase with wegen 'because of':

$$
\begin{array}{|l|}
\hline Z=\mathrm{III} \\
\hline \text { 1. wegen } N_{\text {gen }} \\
\hline
\end{array}
$$

1. Angst wegen ihrer Brutalität 'the fear because of her brutality'

\subsection{Restricted Lexical Co-occurrence of Emotion Lexemes in German}

We present here the raw data on the restricted lexical co-occurrence of the forty emotion lexemes with the chosen twenty-five verbs, see Subsection 1.2. These data have partially been obtained from the corpora of the Institut für Deutsche Sprache (IDS), Mannheim,'15 in cases where these corpora did not give sufficient evidence for the acceptability of specific collocations, the judgements have been left to the linguistic intuition of the authors. Their decisions as to what is possible/ impossible in this domain were checked by ten native speakers and buttressed by a few findings from literary texts. However, due to the lack of a representative corpus and a systematic sociolinguistic research, the acceptability judgements which underlie this paper might be questioned. Even more so, since we discovered, during a few additional checks, that speakers have widely divergent opinions on acceptability of collocations in question. ${ }^{16}$ This had to be expected since this type of collocation is notorious for the problems it poses to the speakers: on the one hand, in numerous cases, speakers have radically different opinions about acceptability; on the other hand, a speaker is often quite uncertain and cannot make up his/her mind. In the face of this diversity, we adopt the following policies: 
1. If the collocation is accepted by an obvious majority (at least $60 \%$ ) of the subjects and/or is well-attested in the corpora, we mark it as grammatical $(' x$ '), independently of the authors' linguistic intuition.

2. If the collocation is accepted by a slight majority (less than $60 \%$ ) of the subjects and there is no sufficient evidence for it in the corpora, yet it is acceptable to the authors' linguistic intuition, we still mark it as grammatical.

3. If the collocation is accepted by about a half of the subjects, there is no clear evidence in the corpora and the authors have no strong intuition, either, we mark it as possible but questionable (" $\left.{ }^{\prime \prime}\right)$.

4. In all other cases, the hypothetical collocations are considered to be ungrammatical.

The data that we have collected are presented in a table, where the rows hold our emotion lexemes and the columns correspond to specific values of certain LFs (see Figure 2 on the following pages). For the sake of a convenient representation, the names of some LFs as they appear in Figure 2 are incomplete; their full specifications are given in Appendix B, Section 2. The translations of the LF values are also given in this section.

\section{Towards a More Efficient Representation of Lexicographic Information}

This section is the central part of our paper. It presents the actual proposal for using lexical inheritance in an ECD and illustrates it. We begin by discussing the correlations between if values and meaning in full lexical entries of the German emotion lexemes (Subsection 4.1).$^{17}$ Next we indicate a possibility for implementing Syntactic Inheritance, more specifically - the inheritance of GPS of emotion lexemes (Subsection 4.2). Then we formulate explicitly our proposal for extracting common lexical co-occurrence in order to get compressed lexical entries (Subsection 4.3). To illustrate the effect of its application, we quote three sample full lexical entries as they would appear before applying our proposal (Subsection 4.4.1) and the compressed lexical entries of the same three lexemes as they appear after applying our proposal (Subsection 4.4.2).

\subsection{Discussion of Lexical Co-occurrence / Meaning Correlations}

At present, an ECD describes restricted lexical co-occurrence by specifying, for each head lexeme $L$, all the values of all applicable LFs in L's entry explicitly - ignoring possible co-occurrence/meaning correlations and regardless of resulting redundancy. Yet many different emotion lexemes have the same value for a given Lexical Function: of. Oper $1(X)=$ hegen '[to] harbor' with $X=$ \{ACHTUNG 'respect', GROLL 'grudge', MOFFNUNG 'hope', LEIDENSCHAFT 'passion', ZUNEIGUNG 'affection'\}. Figure 2 clearly shows how widespread this phenomenon is. 
Figure 2.1: Sample data for representatives of the Oper $_{1}$ LF Group

\begin{tabular}{|c|c|c|c|c|c|c|c|c|c|}
\hline I.F & \multicolumn{5}{|c|}{ Oper, } & \multicolumn{3}{|c|}{ IncepOper, } & $r$ \\
\hline $\begin{array}{l}\text { Key } \\
\text { Lexeme }\end{array}$ & $\begin{array}{l}\text { E } \\
\text { E⿱ } \\
\text { E } \\
\text { E } \\
\end{array}$ & 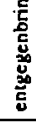 & $\frac{\text { s }}{\frac{5}{5}}$ & 돌 & $\begin{array}{l}5 \\
5 \\
20 \\
2\end{array}$ & 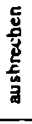 & $\begin{array}{l}\frac{E}{\mathrm{U}} \\
\frac{\mathrm{E}}{\mathrm{E}} \\
\frac{\bar{z}}{\mathbf{z}}\end{array}$ & 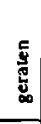 & $\begin{array}{l}5 \\
\mathbf{5} \\
\mathbf{4} \\
\mathbf{5} \\
\end{array}$ \\
\hline ACHTUNG & $x$ & 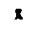 & 8 & $x$ & $x$ & & $\mathbf{x}$ & & \\
\hline ANGST & $x$ & & $x$ & $x$ & & & $\mathbf{x}$ & & $x$ \\
\hline ÄRCil:R & $x$ & & & & & & & & \\
\hline AUIIREGUNG & & & & & & $?$ & & $x$ & $x$ \\
\hline BEDAUERN & $x$ & & $x$ & & & & & & \\
\hline BEGEISTERUNG & $x$ & & $?$ & & & $x$ & & $x$ & $x$ \\
\hline EIFIRSUCIT & 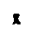 & & $x$ & & & & & & \\
\hline EKEL & $x$ & & $x$ & e & & & $x$ & & \\
\hline EMPÖRUNG & $x$ & & & & & & & & \\
\hline ENTSETZZI:N & $x$ & & & & & & & & \\
\hline ENTTÄUSCIUUNG & $x$ & & $x$ & & & & & & \\
\hline ENTZÜCKEN & & & & & & & & $x$ & $x$ \\
\hline ERRFGUNG & $x$ & & $x$ & & & & & $x$ & $x$ \\
\hline FREUDE & $x$ & & $x$ & $x$ & & $x$ & & $x$ & $x$ \\
\hline FURCITT & $x$ & & $\mathbf{x}$ & $x$ & & & $?$ & & $\mathbf{x}$ \\
\hline GROLL. & $x$ & & $x$ & $x$ & $x$ & & & & \\
\hline IIASS & $x$ & $x$ & $x$ & $x$ & & & $x$ & & \\
\hline HOFFNUNG & $\mathbf{x}$ & & $?$ & $x$ & $x$ & & $x$ & & \\
\hline LEIDENSCHAFT & $x$ & & & $x$ & $x$ & & & & \\
\hline LEBE & $x$ & $x$ & $x$ & & & & & & \\
\hline MITLED & $x$ & $x$ & $x$ & $\mathbf{x}$ & & & $x$ & & \\
\hline NEID & $x$ & & $x$ & & & & & & \\
\hline PANIK & & & $x$ & & & $\mathrm{x}$ & $\mathrm{x}$ & $\mathrm{x}$ & $\mathrm{x}$ \\
\hline REUE & $x$ & & $x$ & & & & & & \\
\hline RÜHRUNG & $x$ & & $x$ & & & & & & \\
\hline SCHADENFRFUDE & $x$ & & $x$ & & & & & & \\
\hline SCHAM & $x$ & & $?$ & $\mathbf{x}$ & & & & & \\
\hline SCHEU & $x$ & & $x$ & $x$ & & & $x$ & & \\
\hline SCHRECK & $\mathbf{x}$ & & $x$ & & & & $x$ & & $x$ \\
\hline STAUNEN & & & & & & & & $\mathbf{x}$ & $\mathrm{x}$ \\
\hline TRAUER & $x$ & & $x$ & & & & & & \\
\hline VERACHTUNG & $x$ & $x$ & $x$ & $x$ & 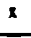 & & & & \\
\hline VERÄRGERUNG & $x$ & & $x$ & & & & & & \\
\hline VERDRUA & $x$ & & & & & & & & \\
\hline VERLEGENHEIT & $x$ & & $x$ & & & & & $x$ & \\
\hline VER WUNDERUNG & & & & & & & & & \\
\hline VERZWEIFLUNG & $\mathbf{x}$ & & $\mathbf{x}$ & & & $x$ & & $\mathbf{x}$ & \\
\hline WUT & $\mathbf{x}$ & & $\mathbf{x}$ & $\mathbf{x}$ & & $\mathbf{1}$ & $\mathbf{1}$ & $\mathbf{x}$ & $\mathbf{x}$ \\
\hline ZORN & $\mathbf{x}$ & & $\mathbf{x}$ & $\mathbf{x}$ & & $\mathbf{x}$ & $\mathbf{x}$ & $\mathbf{x}$ & $\mathbf{x}$ \\
\hline ZUNEIGUNG & $x$ & $\mathbf{x}$ & $\mathbf{x}$ & $\mathbf{x}$ & $\mathbf{x}$ & & & & \\
\hline
\end{tabular}
Ceusoper, 
Figure 2.2: Sample data for representatives of the Func LF Group

\begin{tabular}{|c|c|c|c|c|c|c|c|c|c|c|c|c|c|c|c|c|c|}
\hline LF & & pru & & & & & & $\cos$ & $\ln$ & & & $2 n$ & $\log _{0}$ & & $\bar{r}$ & 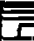 & \\
\hline Keg & 흘 & $\frac{8}{8}$ & 8 & 量 & $\frac{5}{8}$ & 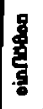 & $\frac{8}{8}$ & $\frac{8}{8}$ & $\begin{array}{l}8 \\
8 \\
6 \\
6\end{array}$ & 最 & 8 & $\frac{8}{\frac{8}{2}}$ & $\frac{5}{8}$ & $\begin{array}{l}5 \\
\frac{8}{8} \\
8 \\
8\end{array}$ & $\begin{array}{l}\frac{5}{3} \\
\frac{3}{3} \\
\text { है }\end{array}$ & $\frac{8}{8}$ & 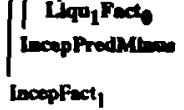 \\
\hline ACHTUNG & $x$ & & & & & $\mathbf{I}$ & & & & & & & & $\mathbf{x}$ & & & \\
\hline ANGST & $x$ & $x$ & $x$ & $\mathbf{x}$ & & 1 & $\mathbf{x}$ & $\mathbf{x}$ & $x$ & 1 & $x$ & $x$ & $\mathbf{x}$ & $x$ & $\mathbf{x}$ & $\mathbf{x}$ & \\
\hline ÄRGER & $x$ & & & & & & 1 & $\mathbf{x}$ & & & & $x$ & 2 & $x$ & $\mathbf{x}$ & I & \\
\hline AUFREGLNG & $x$ & & & & & & & $\mathbf{x}$ & & & & $x$ & $\mathbf{x}$ & & $\mathbf{x}$ & $x$ & \\
\hline BEDAUERN & $x$ & $\mathbf{x}$ & & $\mathbf{x}$ & & & & $\mathbf{x}$ & & & $x$ & & & & & & \\
\hline BEGELSTERUNG & $x$ & $x$ & $x$ & $x$ & 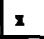 & & & $x$ & & & $x$ & $x$ & $\mathbf{x}$ & $\mathbf{x}$ & $\mathbf{x}$ & $x$ & \\
\hline EIFERSUCHT & $x$ & $x$ & $x$ & $x$ & & & 1 & & & 1 & $x$ & $x$ & $x$ & $x$ & $x$ & $x$ & \\
\hline EKEL & $x$ & $x$ & & $I$ & & & $\mathbf{x}$ & $\mathbf{x}$ & & & & & & $\mathbf{x}$ & $\mathbf{x}$ & & \\
\hline EMPORUNG & $x$ & $x$ & & $\mathbf{x}$ & & & $\mathbf{x}$ & $\mathbf{x}$ & & $\mathbf{x}$ & & $\mathbf{x}$ & $\mathbf{x}$ & $\mathbf{x}$ & $\mathbf{x}$ & $x$ & \\
\hline ENISETZEN & $x$ & $x$ & $x$ & $x$ & & & & $\mathbf{x}$ & & & & $x$ & & $\mathrm{x}$ & $\mathbf{x}$ & 1 & \\
\hline ENTTÄUSCHUNG & $x$ & $x$ & & $\mathbf{x}$ & $\mathbf{z}$ & & & $\mathbf{x}$ & & & & $x$ & $x$ & $\mathbf{x}$ & $\mathbf{x}$ & $\mathbf{I}$ & $\cdot$ \\
\hline ENTZUCKEN & & & & & & & & $\mathbf{x}$ & & & & & & & $?$ & & \\
\hline ERREGUNG & $x$ & $x$ & $\mathbf{x}$ & $\mathbf{I}$ & & & & & & & & $x$ & $\mathbf{x}$ & $\mathbf{x}$ & $\mathbf{x}$ & $x$ & \\
\hline FREUDE. & $x$ & $x$ & $x$ & $x$ & $\mathbf{x}$ & & $\mathbf{x}$ & $\mathbf{x}$ & $x$ & & & $x$ & $\mathbf{x}$ & $x$ & $\mathbf{x}$ & $x$ & \\
\hline FURCHT & $?$ & $x$ & & $\mathbf{x}$ & & $\mathbf{x}$ & $\mathbf{x}$ & $\mathbf{x}$ & & $x$ & $x$ & $x$ & $\mathbf{x}$ & 1 & $\mathbf{1}$ & $\mathbf{x}$ & \\
\hline GROLL & $x$ & $x$ & & . & & & $\mathbf{x}$ & $\mathbf{x}$ & & 7 & & $x$ & $x$ & $\mathbf{x}$ & $\mathbf{x}$ & & \\
\hline HASS & $\mathbf{x}$ & $\mathbf{x}$ & $x$ & $x$ & & & $\mathbf{x}$ & $\mathbf{x}$ & & $x$ & $\mathbf{x}$ & & & $x$ & $\mathbf{x}$ & & \\
\hline HOFFNUNG & $x$ & 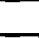 & & & & $x$ & & & $\mathbf{I}$ & & $x$ & & $\mathbf{x}$ & 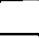 & $\mathbf{x}$ & $\mathbf{x}$ & \\
\hline LEDENSCHAFT & & $x$ & $x$ & $\mathbf{x}$ & 1 & & & & & $x$ & $x$ & $i$ & 7 & $x$ & $x$ & $\mathbf{x}$ & \\
\hline LEBE & & $?$ & & & 1 & & & & & & & & & $x$ & $\mathbf{x}$ & $\mathbf{x}$ & \\
\hline MTTLEID & $x$ & $x$ & & $\mathbf{x}$ & $x$ & $x$ & $\mathbf{x}$ & $\mathbf{x}$ & & & $x$ & & $x$ & $\mathbf{x}$ & 1 & $\mathbf{x}$ & \\
\hline NET & $x$ & $x$ & & $\mathbf{x}$ & & & $\mathbf{x}$ & $\mathbf{x}$ & & $x$ & $\mathbf{x}$ & & $\mathbf{x}$ & $x$ & 1 & & \\
\hline PANIK & $x$ & $x$ & $x$ & 1 & & & $\mathbf{x}$ & $x$ & & $x$ & & $x$ & & $\mathbf{x}$ & $x$ & $\mathbf{x}$ & \\
\hline REUE & $\mathbf{x}$ & $x$ & $x$ & $\mathbf{x}$ & $\mathbf{x}$ & & & & & & & & & & & & \\
\hline RUHRUNG & $\mathbf{x}$ & $x$ & & $x$ & $x$ & & & & & & & $x$ & $\mathbf{x}$ & $\mathbf{x}$ & $\mathbf{x}$ & & \\
\hline SCHADENFREUDE & $x$ & $x$ & & $\mathbf{x}$ & . & & $\mathbf{x}$ & $\mathbf{I}$ & & & & & $\mathbf{x}$ & $\mathbf{x}$ & $\mathbf{x}$ & & \\
\hline SCHAM & $x$ & $x$ & & $x$ & $x$ & & & $\mathbf{x}$ & & & & & & $x$ & & & \\
\hline SCHEU & & $x$ & & $\mathbf{x}$ & & & & & & & & $\mathbf{x}$ & $\mathbf{x}$ & $x$ & & & \\
\hline SCHRECX & & $x$ & $\mathbf{x}$ & $x$ & & & & $?$ & & & & 1 & $x$ & $x$ & & 1 & \\
\hline STAUNEN & $\mathbf{x}$ & $x$ & $x$ & $x$ & & & 1 & $\mathbf{x}$ & & & & $x$ & & & $\mathbf{I}$ & & \\
\hline TRAUER & $\mathbf{x}$ & $x$ & & $x$ & 1 & & & & & & & & $\mathbf{x}$ & $x$ & & & \\
\hline VERACHTUNG & $x$ & & & $\mathbf{x}$ & & & & $\mathbf{x}$ & & & $\mathbf{x}$ & & & $\mathbf{x}$ & 1 & & \\
\hline VERARGERUNG & $\mathbf{x}$ & & & & & & $x$ & $\mathrm{x}$ & & & & $x$ & $x$ & & 1 & 1 & \\
\hline VERDRUSS & $x$ & & & & & & $\mathbf{x}$ & & $\mathbf{x}$ & & & $x$ & $\mathbf{x}$ & & $\mathbf{x}$ & & \\
\hline VERLEGENHET & $x$ & $x$ & & $\mathbf{I}$ & & & & $x$ & & & & $\mathrm{x}$ & $x$ & $\mathrm{x}$ & & $\mathbf{x}$ & \\
\hline VER WUNDERUNG & $x$ & & & & & & $x$ & $x$ & & & & & 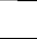 & & $x$ & & \\
\hline VERZWEIFLUNG & $x$ & $\mathbf{x}$ & $\mathbf{x}$ & $x$ & I & & & $\mathbf{x}$ & & & & $x$ & & $\mathbf{x}$ & & $\mathbf{x}$ & \\
\hline mut & $\mathbf{x}$ & $\mathbf{x}$ & $\mathbf{x}$ & $\mathbf{x}$ & & & & $\mathbf{x}$ & & $\mathbf{x}$ & & $x$ & $\mathbf{x}$ & $\mathbf{x}$ & $\mathbf{x}$ & $\mathbf{x}$ & \\
\hline ZORN & $x$ & $x$ & $x$ & $\mathbf{x}$ & & & $\mathbf{x}$ & $\mathbf{x}$ & & $\mathbf{x}$ & $x$ & $x$ & $x$ & $\mathbf{x}$ & $\mathbf{x}$ & $\mathbf{x}$ & \\
\hline ZUNEIGUNG & $x$ & $x$ & & $\mathbf{x}$ & $x$ & & & $\mathbf{x}$ & & & & & & $\mathbf{x}$ & & & \\
\hline
\end{tabular}


This gives rise to the two following questions:

1. Is it possible to avoid the tedious repetition of the same value of a given LF $f$ by specifying this value just once for many or even for all of the keywords concerned, gaining thus a substantive generalization?

2. If yes, how to present in an ECD the generalized specification of LFs?

German emotion lexemes taken as bases behave similarly with respect to at least two collocates: empfinden '[to] perceive' and fühlen '[to] feel'. Nearly all of them cooccur with empfinden, and so does the noun GEFüHL 'emotion'; fühlen '[to] feel' is also nearly universal, although less so, for the same lexemes. ${ }^{18}$ Therefore, a generalization along the following lines seems possible:

The definitions of all German emotion lexemes contain a common component: 'emotion', expressed by the German lexeme GEFÜHL; thus, GEFÜHL is the generic lexeme of the semantic field of emotions in German. Then, for emotion lexemes, the verbs empfinden and fühlen are specified only once - in the lexical entry of the generic lexeme GEFÜHL. 'emotion' as values of the $L F$ Oper $_{1}$. All specific lexemes denoting emotions, i.e. containing the component 'Gefühl' in their definitions, should then inherit this value of Oper ${ }_{1}$ from the lexeme GEFÜHL.

Unfortunately, as a general rule, there is no unique correlation between the values of LFs applicable to the generic lexeme and the values of the same LFs applied to the specific descendants of the latter (cf. Heid and Raab 1989). Thus, even empfinden does not combine with five out of forty emotion lexemes and fühlen. with ten (see Figure 2.1). Furthermore, the verb erleben (Oper ${ }_{1}$ ) goes with ENTTÄUSCHUNG 'disappointment', while schöpfen (Incep ${ }_{1}$ Oper $_{1}$ ) and machen (CausFunc $1_{1}$ ) with HOFFNUNG hope; but all these verbs do not combine with GEFÜHL:

Oper $_{1}$ (GEFÜHL)

IncepOper ${ }_{1}$ (GEFÜHL)

CausFunc $_{1}$ (GEFÜHL)

$$
\begin{aligned}
& =\text { empfinden, "erleben } \\
& =\text { "schöpfen } \\
& =\text { erwecken, "machen, wachrufen }
\end{aligned}
$$

Similar examples can be multiplied endlessly.

The absence of a strict enough correspondence between $L F$ values in the entry of GEFUHL and those in the individual entries of emotion lexemes is due to a very high degree of idiosyncrasy in the LF Verb + Noun "collocations". This idiosyncrasy can be characterized from the viewpoint of the verb as well as that of the noun.

Speaking of $L F$ verbs: An $L F$ verb can combine with one particular lexeme or a small group of nearly synonymous lexemes, while refusing the combinations with other quasi-synonyms or antonyms. For example, machen '[to] make' as the value of CausFunc ${ }_{1}$ combines with ANGST 'fear' but not with FURCHT 'fright' and 
PANIK 'panic'; with FREUDE 'joy' but not with BEGEISTERUNG 'enthusiasm' and SCHADENFREUDE 'malicious joy'; and with HOFFNUNG 'hope' but not with VERZWEIFLUNG 'despair'.

To illustrate from a different domain, Germ. bestellen '[to] till' as Real ${ }_{1}$ value co-occurs only with FELD 'field', ACKER 'field', and LAND 'land' (das Feld / Acker / Land bestellen) ${ }^{19}$ but not, e.g., with measure phrases such as drei Hektar 'three hectares' in contrast to its closest synonym BEBAUEN '[to] till':

(2) Er hat drei Hektar 'bestellt/ bebaut lit. 'He tilled three hectares'.

The verb REITEN '[to] ride' as Oper 1 value co-occurs only with ATTACKE '(verbal) attack' (eine Attacke gegen $N_{a c c}$ reiten '[to] launch a (verbal) attack against $\mathrm{N}^{\prime}$, lit. '[to] ride an attack'). The closest synonym of ATTACKE - ANGRIFF 2 '(verbal) attack' - has no Oper 1 value at all; rather it has instead an Oper $_{2}$ value: [einem Angriff] ausgesetzt sein '[to] be exposed [to an attack]'.

Speaking of nouns in "LF Verb + Noun" collocations: Nouns which have similar or identical lexical co-occurrence may fail to form a natural semantic subclass. Thus, ANGST 'fear', WUT 'rage', and LEIDENSCHAFT 'passion' readily co-

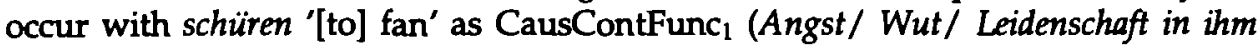
schüren lit. 'to fan fear/ rage/ passion in him'); ${ }^{20}$ yet ANGST 'fear', WUT 'rage' and LEIDENSCHAFT 'passion', as well as other admissible key lexemes (see Figure 1) do not form an identifiable semantic subclass of emotion lexemes. (This means that it is impossible to specify the set including these and only these lexemes in terms of their semantic features.)

The cases of both of the above types do not admit of any meaningful generalization; the only feasible solution here is to specify each instance of restricted lexical co-occurrence individually.

As a result, we face two extremes: either a whole semantic class of lexemes showing a (nearly) identical restricted lexical co-occurrence (empfinden and fühlen with GEFÜHL-lexemes); or individual lexemes featuring completely idiosyncratic, non-generalizable co-occurrence (machen with ANGST 'fear', FREUDE 'joy', and HOFFNUNG 'hope'). However, in natural language intermediate cases abound: some members of a semantic class show somewhat similar restricted lexical cooccurrence. For instance, within the German emotion lexemes class some, but not all, members co-occur with entgegenbringen '[to] show' as Oper ${ }_{1}$ : jemandem Achtung/ Haß/ Mitleid entgegenbringen '[to] show so. respect/ hatred/ compassion', but not jemandem "Verdruß/ * Empörung / "Verwunderung entgegenbringen '[to] show so. vexation/ indignation/ amazement'. Furthermore, ANGST 'fear', BEGEISTERUNG 'enthusiasm', ENTTÄUSCHUNG 'disappointment' co-occur with erfassen '[to] overcome' as IncepFunc ${ }_{1}$ - just as many other emotion lexemes do; yet AUFREGUNG 'excitement', ENTZÜCKEN 'delight', SCHRECK 'terror' and a few more do not.

This is with such intermediate cases that we deal in the present paper. In other words, we set out to find some regularities in the domain which is irregular 
by definition.

To do so, we take two sets of "processed" data:

1. The set of the abridged lexicographic definitions for forty emotion lexemes, i.e. the characterization of the lexemes in terms of eleven semantic "dimensions" (introduced in Subsection 3.1). This set is represented in Figure 1.

2. The set of the LF values specifications for the same forty lexemes - restricted to the twenty-five collocate verbs investigated. This set is presented in Figure 2.

Starting from this data, we try to find the optimal correlation between the values of LFs and semantic features in the abridged definitions. (By "optimal" we mean such a correlation that ensures the maximal generalization with the minimal number of individual exceptions, i.e. the best information compression possible.) As will be shown in Appendix B, Section 3, several such correlations exist, so that Question 1 at the beginning of this section has to be answered in the positive: substantive generalizations over LF values can and should be stated. Therefore, we have to answer Question 2, i.e. to propose a lexicographic format that is able to cope with such generalizations. We will do that in Subsection 4.3, relying on the ECDformalism introduced above.

\subsection{Implementing Syntactic Inheritance in an ECD}

Before tackling the more general problem of lexical inheritance implementation, let us consider the problem of a more efficient representation of GPs, i.e. of syntactic inheritance, in an ECD (the topic of syntactic inheritance is intensively elaborated, e.g., in work by K. Hale et al. (Hale and Keyser 1986) and B. Levin (Levin 1989, 1993).

First Actant. In Subsection 3.2, we saw that the surface means used in German to express the corresponding syntactic actant I (= the Experiencer) are identical for all the lexemes considered. This allows for the generalization of the GP information for $x$, so that the first column of the GP of all the forty emotion lexemes is represented as illustrated in Subsection 3.2.

Given this generalization, the first column of the GP will not be repeated in the lexical entries of all the emotion lexemes but will be given only once: with the generic lexeme GEFÜHL, see Subsection 4.5.

Second Actant. The variety of the expressive means for the DSyntA II (= the Source/ the Object of the emotion) (see Subsection 3.2) does not allow for an overall generalization of the second column of the GP of our emotion lexemes (as we have just done for the DSyntA I). However, some of these surface means are shared by several lexemes. For instance: 
1. DSyntA II is expressed by über 'over'/ 'about' (and darüber lit. 'over it'/ 'about it') in twenty-three lexemes, which include ÄRGER 'anger', AUFREGUNG 'excitement', BEDAUERN 'regret', etc.

2. DSyntA II is expressed by auf 'on' (and darauf lit. 'on it') in eight lexemes (EIFERSUCHT 'jealousy', GROLL 'grudge', HASS 'hatred', etc.).

3. DSyntA II is expressed by vor 'because' (and davor lit. 'because of it') in six lexemes (ACHTUNG 'respect', ANGST 'fear', EKEL 'disgust', etc.).

Such subregularities suggest the possibility of at least partial generalizations. In fact, only one generalization is actually possible: most of the emotion lexemes that govern their DSyntA II via über are 'reactive'; consider the second column of the GP of the 'reactive' emotion lexeme FREUDE 'joy'. Consequently, the second actant of 'reactive' lexemes can be readily generalized.

$$
\begin{aligned}
& \mathrm{Y}=\mathrm{II} \\
& \text { 1. über } \mathrm{N}_{a c c} \\
& \text { 2. (darüber,) daß PROP }
\end{aligned}
$$

1. die Freude über ihr Kommen 'the joy over her coming'.

2. die Freude (darüber), daß sie noch kommt 'the joy (over it) that she is still coming. ${ }^{21}$

For non-'reactive' lexemes, generalization is too costly (it requires too many exceptions); therefore, the second column in the GP of all 'reactivity-neutral' lexemes will be individually stated in their lexical entries.

Third Actant. The surface means used to express the corresponding DSyntA III (= the Cause of the emotion) is identical for all the emotion lexemes which are three-actantial.

Therefore, the information about the realization of $z$ can be represented similarly to the first column - only once; it will be presented in the GP of the generic lexeme GEFÜHL in its "public" entry (see Subsection 4.5). ${ }^{22}$

\subsection{Implementing Lexical Inheritance Principle in an ECD}

\subsubsection{Co-occurrence Inheritance Technique in an ECD}

Our proposal can be stated in terms of the following five steps:

1. Delimiting the semantic field under analysis and preparing full-fledged lexical entries for each of the chosen lexemes.

2. Determining the generic lexeme of the field and elaborating its lexical entry. 
This process may lead to an improvement of the definitions in the field: they are made more standard.

3. Introducing semantic features capable of capturing relevant semantic commonalities in full-fledged definitions; deriving abridged definitions expressed in terms of semantic features. This step may bring about a further standardization of the original definitions.

4. Extracting the commonalities in GPS and LF values found in the lexical entries of specific lexemes and transferring them to the lexical entry of the generic lexeme. (The latter, thereby, acquires quite a new status, see immediately below.) While doing this, the researcher has to make sure that.

First, each transferred element is supplied with semantic conditions which license its use with the specific lexeme it has been extracted from. These conditions are formulated in terms of the semantic features.

Second, each element which constitutes an exception is explicitly marked as such in the corresponding entry. For instance, a verb $v$ that collocates with all emotion lexemes of a given type except the lexeme 1 has to be specified in l's entry as contradicting the inheritance rule: " $\neg$ ", see below, Subsection 4.5.

5. Reorganizing the lexical entry of the generic lexeme by dividing it into two parts: its own lexical entry (describing its own syntax and co-occurrence - so to speak, its "private" subentry) and the subentry for the extracted commonalities of the field, or the "public" subentry (see below).

\subsection{Full vs. Compressed Lexical Entries: ANGST, HOFFNUNG, WUT}

To contrast our proposal with the current representation of lexical entries in the ECD, we give in what follows three examples of lexical entries for German emotion lexemes: first as they would appear in a "traditional" ECD of German, i.e. in the "full" form, and then the same entries as they appear after the application of the proposed techniques, i.e. in the "compressed" form.

\subsubsection{Three Full Lexical Entries of a German ECD}

To make our presentation more illustrative, we indicate - in boldface - the items which can be dispensed with thanks to the inheritance technique, i.e. which can be extracted from these individual entries and stored under the generic lexeme.

Note that these entries are by no means complete: Firstly, they do not contain the full-fledged definitions. Secondly, these entries cover the restricted lexical cooccurrence of the head lexemes only within the limits of the twenty-five verbs under consideration. Such current collocations as jemandem Angst einjagen '[to] give sb. a fright', Hoffnung verlieren '[to] loose hope', and Wut ergriff ihn 'The rage seized him' are not represented. Thirdly, the use of determiners in noun + verb collocations (represented in the GP of the collocate verb) is a problem of its own. We did not study it systematically and limit ourselves to approximate indications. 
For notations, see the table at the end of the paper; absence of an indication means obligatory absence of determiners.

NB: The expression "fast", for example in "Magn + fast IncepFunc," below, is an English word denoting a non-standard LF. It means that the LF value (e.g., verfliegen, erfassen, and packen below) implies a fast-developing event : Seine Angst legte sich allmählich 'His fear lied down gradually', but not "Seine Angst verflog allmählich 'His fear vanished gradually'.

1. ANGST, fem

\section{Definition}

Angst von $X$ vor $Y$ wegen $Z=$ ' $X$ 's fear of $Y$ because of $Z$ ' $=X$ 's unpleasant, reactive, active, excited-state, self-control-loss-inflicting, permanent or temporary Gefühl directed at $Y$ because of $Z$

\begin{tabular}{|l|l|l|}
\hline $\mathbf{X}=\mathbf{I}$ & $\mathrm{Y}=\mathrm{II}$ & $\mathrm{Z}=\mathrm{III}$ \\
\hline $\begin{array}{l}\text { 1. } \mathbf{N}_{\text {gen }} \\
\text { 2. von } \mathbf{N}_{\text {dat }}\end{array}$ & 1. vor $\mathbf{N}_{\text {dat }}$ & 1. wegen $\mathbf{N}_{\text {gen }}$ \\
3. Pron $\mathbf{V}_{\text {inf }}$ & 3. daß PROP & \\
\hline
\end{tabular}

\section{Lexical Functions}

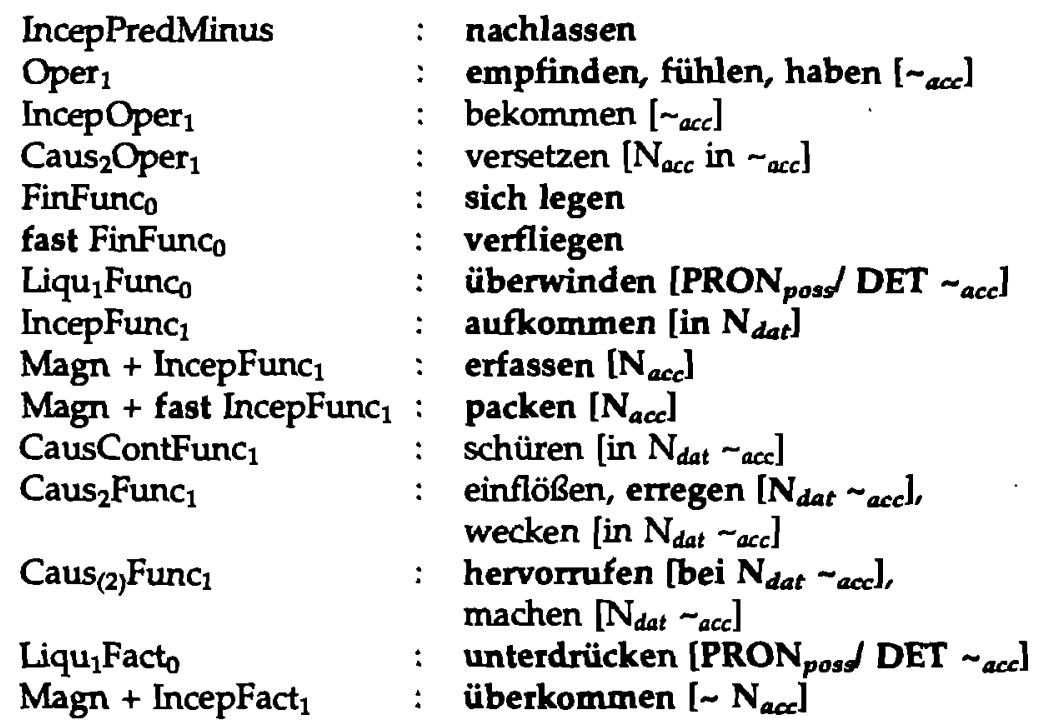


2. HOFFNUNG, fem

Hoffnung oon $X$ auf $Y^{\prime} X^{\prime}$ 's hope for $Y^{\prime}=X^{\prime}$ 's pleasant, mental, permanent Gefühl [caused by $X$ 's belief and desire that $Y$ takes place]

\begin{tabular}{|l|l|}
\hline $\mathbf{X}=\mathbf{I}$ & $\mathbf{Y}=\mathrm{II}$ \\
\hline $\begin{array}{l}\text { 1. } \mathbf{N}_{\text {gen }} \\
\text { 2. von } \mathbf{N}_{\text {dat }}\end{array}$ & 1. auf $\mathbf{N}_{a c c}$ \\
2. daß PROP \\
\hline
\end{tabular}

IncepPredMinus

Oper $_{1}$

IncepOper,

fast FinFunc ${ }_{0}$

IncepFunc $_{1}$

CausFunc $_{1}$
: nachlassen

: empfinden, haben, hegen [ - acc], 'fühlen

: bekommen $\left[\sim_{\text {acc }}\right]$

: verfliegen

: aufkommen [in $\mathbf{N}_{\text {dat }}$ ]

: einflößen, machen $\left[\mathbf{N}_{d a t} \sim\right.$ acc $]$, wecken [in $\mathrm{N}_{\text {dat }} \sim$ acc]

3. WUT, fem

Wut von $X$ über $Y$ wegen $Z^{\prime} X$ 's rage at because of $Z^{\prime}=X^{\prime}$ 's intense, unpleasant, manifested, reactive, active, excited-state, self-controlloss-inflicting Gefühl directed at $Y$ because of $Z$

\begin{tabular}{|l|l|l|}
\hline $\mathbf{X}=\mathbf{I}$ & $\mathrm{Y}=\mathrm{II}$ & $\mathrm{Z}=\mathrm{III}$ \\
\hline $\begin{array}{l}\text { 1. } \mathbf{N}_{\text {gen }} \\
\begin{array}{l}\text { 2. von } \mathbf{N}_{d a t} \\
\text { 3. Adj } \text { Aoss }_{\text {pos }}\end{array}\end{array}$ & $\begin{array}{l}\text { 1. auf } \mathbf{N}_{a c c} \\
\text { 2. über } \mathbf{N}_{a c c}\end{array}$ & 1. wegen $\mathbf{N}_{\text {gen }}$ \\
\hline
\end{tabular}

IncepPredMinus

Oper $_{1}$

IncepOper 1

Magn + IncepOper

Caus $_{2}$ Func $_{1}$

Caus $_{(2)}$ Oper $_{1}$
: nachlassen

: empfinden, fühlen, haben [DET/ acc]

: bekommen [DET accl, geraten [in acc]

: ausbrechen [in $\left.\sim_{\text {acc }}\right]$

: erregen [in $\mathbf{N}_{\text {dat }} \sim$ accl, hervorrufen [bei $\mathbf{N}_{\text {dat }} \sim$ acc]

$:$ versetzen $\left[\mathrm{N}_{a c c}\right.$ in $\left.\sim_{a c c}\right]$ 


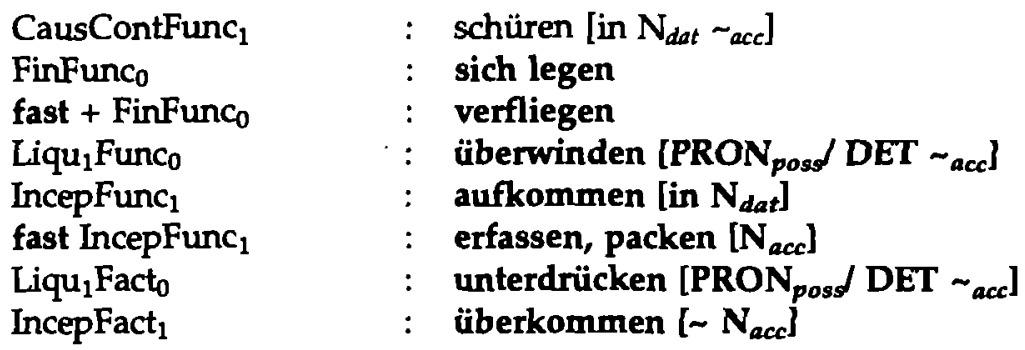

\subsubsection{Three Compressed Lexical Entries of a German ECD}

All compressed lexical entries of the emotion lexemes considered are found in Appendix C.

The symbol " $\uparrow "$ " in front of an LF (see, e.g., Caus ${ }_{2}$ Func $_{1}$ in ANGST) means that the value of this $L F\left(V A L_{\text {spec }}\right)$ must be added to its values specified in the public subentry of GEFÜHL that contains generalized co-occurrences $\left(\mathrm{VAL}_{\text {gener }}\right)$. Without " $\uparrow$ ", $\mathrm{VAL}_{\text {spec }}$ replaces $\mathrm{VAL}_{\text {gener. }}$.

The expression " $\neg X$ ", where $X$ is a collocate verb, means that this verb is impossible as an element of the value of the corresponding LF; this expression marks $X$ as a lexical exception from the list of possible LF values given in the entry of GEFÜHL.

\section{ANGST, fem}

Angst von $X$ vor $Y$ wegen $Z$ ' $X$ 's fear of $Y$ because of $Z^{\prime}=X^{\prime} s$ unpleasant, manifestable, reactive, active, excited-state, selfcontrol-loss-inflicting, permanent or temporary Gefühl directed at $\mathrm{Y}$ because of $\mathrm{Z}$

\begin{tabular}{|l|}
\hline $\mathrm{Y}=\mathrm{II}$ \\
\hline 1. vor $\mathrm{N}_{\text {dat }}$ \\
2. $z u \mathrm{~V}_{\text {inf }}$ \\
3. daß PROP \\
\hline
\end{tabular}

IncepOper 1

$\mathrm{Caus}_{2} \mathrm{Oper}_{1}$

CausContFunc $_{1}$

$\uparrow$ Caus $_{2}$ Func $_{1}$

Caus $_{(2)}$Func $_{1}$ bekommen [ acc]

$:$ versetzen $\left[\mathrm{N}_{\text {acc }}\right.$ in $\left.\sim_{\text {acc }}\right]$

: schüren [in $\mathbf{N}_{d a t} \sim a c c$ ]

: einflößen [ $\mathbf{N}_{d a t} \sim_{\text {acc }}$, wecken [in $\left.\mathbf{N}_{d a t} \sim_{\text {acc }}\right]$

: machen $\left[\mathrm{N}_{d a t} \sim_{a c c}\right]$ 
2. HOFFNUNG, fem

Hoffnung von $X$ auf $Y$ ' $X$ 's hope for $Y^{\prime}$ ' $X^{\prime}$ 's pleasant, mental, permanent Gefüh [caused by $X$ 's belief and desire that $Y$ takes place]

$\mathrm{Y}=\mathrm{II}$

1. auf $\mathrm{N}_{\text {acc }}$

2. daß PROP

IncepPredMinus

†Oper 1

IncepOper 1

fast FinFunc $c_{0}$

Liqu $_{1}$ Func $_{0}$

CausFunc $_{1}$

Magn + IncepFunc 1

(Magn) + IncepFunc $1 \quad$ : $\neg$ überkommen

\section{WUT, fem}

Wut oon $X$ über $Y$ wegen $Z$ ' $X$ 's rage at $Y$ because of $Z^{\prime}=X$ 's intense, unpleasant, manifested, reactive, active, excited-state, self-control-loss-inflicting, temporary Gefühl caused by and directed at $Y$ because of $Z$

: nachlassen

: hegen, ${ }^{7}$ fühlen $\left[\sim_{\text {acc }}\right]$

: bekommen $\left[\sim_{\text {accl }}\right]$

: verfliegen

: ᄀüberwinden

: einflößen, machen $\left[\mathrm{N}_{d a t} \sim a r c\right]$, wecken [in $\mathrm{N}_{\text {dat }} \sim$ acc]

$\neg$ erfassen$$
\text { . }
$$
directed at $Y$ because of $Z$

\begin{tabular}{|l|}
\hline $\mathrm{Y}=\mathrm{II}$ \\
\hline 1. auf $\mathrm{N}_{\mathrm{acc}}$ \\
2. über $\mathrm{N}_{\mathrm{acc}}$ \\
\hline
\end{tabular}

†Oper $_{1}$

IncepOper

$\mathrm{Caus}_{2} \mathrm{Oper}_{1}$

CausContFunc $_{1}$
: haben [DET acc]

$:$ bekommen [DET $\left.\sim_{\text {acc }}\right]$

: versetzen $\left[\mathbf{N}_{a c c}\right.$ in $\left.\sim_{a c c}\right]$

: schüren [in $\mathbf{N}_{d a t} \sim_{\text {acc }}$ ] 


\subsection{The Lexical Entry of GEFÜHL - the Generic Lexeme of the Semantic Field of Emotions}

The noun GEFÜHL is polysemous; here we consider its "emotional" sense; i.e. the sense found in such expressions as:

(6) a. Das Gefühl der Freude/ Ein freudiges Gefiuhl kam in ihm auf lit. 'The feeling of joy/ A joyful feeling came up in him'.

b. Das Gefühl der Trauer ließ ihn nicht mehr los lit. 'The feeling of sorrow did not leave him anymore'.

c. Ein zorniges Gefühl übermannte Elke, als sie ... lit. 'A wrathful feeling overcame Elke when she ...'

d. Ein Gefühl des Glücks duirchströmte Elke, als sie ...

lit. 'A feeling of happiness flowed through Elke when she ...'.

The corresponding lexeme is denoted as $\mathrm{GEFÜHL}_{1}{ }^{23}$ In accordance with Subsection 4.3 above, the lexical entry for $\mathrm{GEFÜHL}_{1}$ is divided into two subentries:

- The subentry of GEFÜHL $L_{1}$ itself as an independent lexeme; this is its own "private", or individual, subentry, which has the same structure as all regular entries in an ECD.

- The subentry of GEFÜHL ${ }_{1}$ as the generic lexeme of the emotion field; this is its "public", or semantic field, subentry, representing the results of generalization over the descriptions of the forty specific emotion lexemes. Its structure differs from that of a regular entry in two aspects:

First, the GP zone contains several GPs, each of these servicing a particular semantic subclass of emotion lexemes. The applicability of a GP is restricted by a condition: a Boolean formula over values of semantic features.

Second, the LF zone contains LF representations in which, instead of one value per lf, a series of different values is given for each function, each of these values servicing a different set of arguments: a particular semantic subclass of emotion lexemes. The applicability of an $L F$ value is restricted by the same type of condition as for the GPS (values of semantic features).

GEFüHL 1 , neutr

\section{Individual (= "Private") Subentry}

$X$ s Gefühl des $W$ gegenüber $Y$ wegen $Z$ ' $X$ 's emotion $W$ towards $Y$ because of $Z^{\prime}$ = State $W$ of $X^{\prime}$ 's psyche caused by (and directed at) $Y$ (and causing that $X$ tends to interact with $Y$ because of $Z^{24}$ ) 


\begin{tabular}{|l|l|l|l|}
\hline $\mathrm{X}=\mathrm{I}$ & $\mathrm{W}=\mathrm{II}$ & $\mathrm{Y}=\mathrm{III}$ & $\mathrm{Z}=\mathrm{IV}$ \\
\hline $\begin{array}{l}\text { 1. } \mathrm{N}_{\text {gen }} \\
\text { 2. oon } \mathrm{N}_{\text {dat }} \\
\text { 3. Pron poss }\end{array}$ & $\begin{array}{l}\text { 1. } \mathrm{N}_{\text {gen }} \\
\text { 2. Adj }\end{array}$ & 1. gegenüber $\mathrm{N}_{\text {dat }}$ & 1. wegen $\mathrm{N}_{\text {gen }}$ \\
\hline
\end{tabular}

Elkes zorniges Gefühl <= Gefiühl des Zornes $>$ gegenüber John wegen seiner Worte Elke's angry feeling < = feeling of anger $>$ towards John because of his words'.

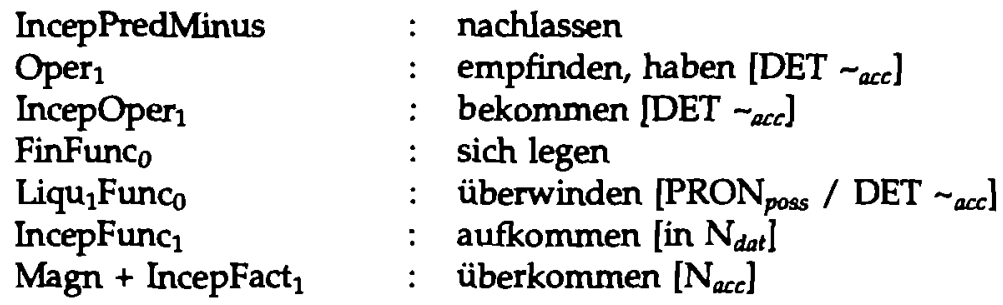

\section{Semantic Field (= "Public") Subentry}

1. All emotion lexemes

An emotion lexeme governs an NP denoting the Experiencer $(X=I)$ and - if it has the SemA $Z$ - an NP denoting the Reason for the emotion $(Z=I I I)$.

\begin{tabular}{|l|l|}
\hline $\mathrm{X}=\mathrm{I}$ & $\mathrm{Z}=\mathrm{III}$ \\
\hline $\begin{array}{l}\text { 1. } \mathrm{N}_{\text {gen }} \\
\text { 2. oon } \mathrm{N}_{\text {dat }}\end{array}$ & 1. wegen $\mathrm{N}_{\text {gen }}$ \\
3. Pron & \\
\hline
\end{tabular}

2. 'Reactive' emotion lexemes

A 'reactive' emotion lexeme governs the NP denoting the stimulus of the emotion $(Y=I)$; in the majority of cases this NP is introduced by the same preposition über.

$$
\mathrm{Y}=\text { II }
$$

1. über $\mathrm{N}_{a c c}$

2. (darüber), daß PROP 


\section{Lexical Functions}

The scope of a semantic condition is to its left up the first semicolon.

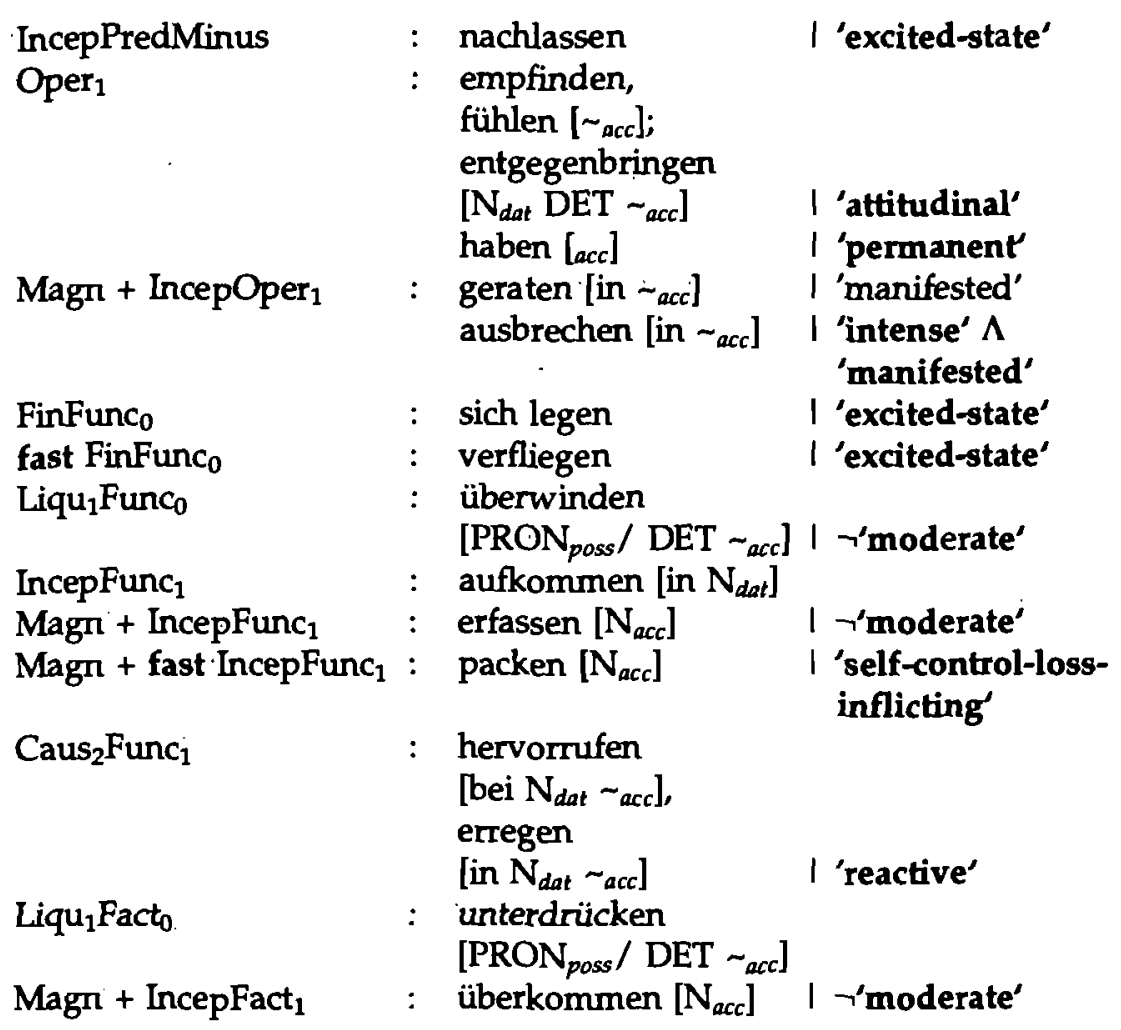

\section{Conclusions}

The study we have described in the present paper results in the five following contributions:

1. preliminary lexicographic descriptions of forty German emotion lexemes (definitions, government patterns, and lexical co-occurrence);

2. introduction of eleven semantic dimensions (= semantic features), aimed at establishing correlations with lexical co-occurrence;

3. formulation of an inheritance technique applicable to restricted lexical cooccurrence in ECD-type lexica;

4. compilation of lexical entries for the forty German emotion lexemes, using the inheritance technique proposed;

5. introduction of the semantic field entry - a "public" subentry that covers a semantic field in the entry of the field's generic lexeme. 
From these contributions it can be readily concluded that the principle of lexical inheritance as applied to the ECD-type lexica is valid.

At least in the field of German emotion lexemes, useful generalizations over GPS and LF values along semantic lines are possible. However, the application of lexical inheritance principle is strongly limited. Thus, often it is impossible to find correlations between lexical co-occurrence of the key lexemes and their semantic features. After all, language is notoriously capricious and inconsistent.

The research reported in this paper can be pursued in the following three ways:

- Our methodology could be extended onto new languages, new semantic fields (e.g., speech act lexemes, weapon and tool lexemes, meteorological phenomena lexemes, etc.), new lexemes of the same field (ABNEIGUNG 'aversion', VERBITTERUNG 'exasperation' ...), new collocate verbs for the same lexemes (for example, for ANGST: loswerden '[to] get rid of', schweben [in] lit. '[to] float in' etc.).

- The current representation of LF values can be improved - for instance, by using the notion of default values. This idea purports that an LF has, generally speaking, a lexical entry of its own, where its different values are specified with respect to rather large and abstract semantic classes. Thus, Oper $_{1}$ has as a value carry out for actions, be in for states, have for properties and parts, etc. Under such a description, the distribution of each default value can be made more precise by having recourse to ever smaller semantic classes Gaatone $(1982,1992)$ deal with this problem). ${ }^{25}$

Another possible way towards a better presentation of LF values is to develop regular lexical entries for them. Thus, it could prove useful to have a fullfledged lexical entry for the verb versetzen '[to] send into' as the value of Caus $_{2}$ Oper $_{1}$ (in Angst versetzen '[to] send into fear'). Such an entry should contain a fine-grained description of contextual distribution of the verb, say, with emotion lexemes. This could lead to a significant simplification of the description of lexical co-occurrence. (This avenue is explored, e.g., in Reuther, (forthcoming).)

- The proposed technique of establishing the co-occurrence/ meaning correlations can be computerized in order to ensure that the set of correlations established is optimal.

\section{Abbreviations and Notations}

$\sim_{a c c / d a t}$
Adj
Adjposs $_{\text {pos }}$
$C_{i}$
DET
DSyntA(L)

keyword instantiation in Accusative/ Dative adjective possessive adjective semantic class I determiner Deep-Syntactic Actant of L 


\begin{tabular}{|c|c|}
\hline ECD & Explanatory Combinatorial Dictionary \\
\hline $\mathrm{f}$ & \\
\hline GP & Government Pattern \\
\hline L & lexical item \\
\hline$L F$ & Lexical Function \\
\hline$\uparrow \mathrm{LF}: \mathrm{X}_{1}, \mathrm{X}_{2}, \ldots, \mathrm{X}_{n}$ & $\begin{array}{l}\text { adding the } L F \text { values } X_{1}, X_{2}, \ldots, X_{n} \text { to the set of } \\
\text { inherited } L F \text { values }\end{array}$ \\
\hline MTM & Meaning-Text Model \\
\hline MTT & Meaning-Text Theory \\
\hline $\begin{array}{l}\mathbf{N}_{(a c c / \text { dat } / g e n)} \\
\text { PRON }\end{array}$ & $\begin{array}{l}\text { noun in Accusative/ Dative/ Genitive } \\
\text { pronoun }\end{array}$ \\
\hline PRON $_{\text {poss }}$ & possessive pronoun \\
\hline PROP & proposition \\
\hline $\operatorname{Sem} A(L)$ & Semantic Actant of $L$ \\
\hline SSynt & Surface Syntactic \\
\hline$V_{\text {inf }}$ & infinitive verb \\
\hline$\neg X$ & $\begin{array}{l}X \text { is impossible as an element of the value } \\
\text { of the corresponding } L F\end{array}$ \\
\hline $\begin{array}{l}X, Y, Z, \ldots \\
I, I I, I I I, \ldots\end{array}$ & $\begin{array}{l}\text { semantic actants } X, Y, Z, \ldots \\
\text { syntactic actants } I, I I, I I, \ldots\end{array}$ \\
\hline
\end{tabular}

\section{Acknowledgements}

The research for the present paper has been started in 1992, while I. Mel'čuk stayed in Germany as a recipient of the Alexander-von-Humboldt Research Award and L. Wanner was affiliated with the Integrated Publication and Information Systems Institute of the GMD in Darmstadt. The work has been continued with the financial support of Canada Research Council Grant 410-91-1844 (I. Mel'cuk) and The Ministry for Research and Science, Baden-Württemberg (L. Wanner). We express our heartfelt gratitude to Ulich Heid, Martin Kay, and Vladimir Turovskij who read the first version of the manuscript; without their remarks and suggestions this paper would not appear in its present form. We are also very grateful to Peter Gerstl, Lidija Iordanskaja, Nikolai Percov, Alain Polguère, Renato Reinau, Tilmann Reuther, Annely Rothkegel, and Wolfgang Schindler, who read the subsequent versions of the text and contributed many valuable comments, and again to Lidija Iordanskaja, for her assiduously plowing once more through the final version and helping us to eradicate innumerable inconsistencies and outright errors. Finally, we would like to thank all the colleagues at GMD who patiently answered again and again our questions concerning their intuition with respect to grammaticality of hundreds of German word combinations. 


\section{Appendix A: Lexical Functions}

In Appendix A, we present a list of LFs used in our research and then short definitions of LFs mentioned in this paper. The most of them are complex LFS or LF configurations, i.e. LF combinations that are composed of simple standard LFs. We list first simple standard LFs and then, LF combinations.

\section{The Ten LFs Used in Our Research}

$\begin{array}{llll}\text { Oper }_{1} & \text { IncepFunc }_{1} & \text { Liqu }_{1} \text { Fact }_{0} & \text { IncepPredMinus } \\ \text { IncepOper }_{1} & \text { CausFunc }_{1} & \text { IncepFact }_{1} & \\ \text { CausOper } & \text { FinFunc }_{0} & \\ & \text { Liqu }_{1} \text { Func }_{0} & \end{array}$

\section{LFs Mentioned in This Paper}

\section{Simple Standard LFs}

1. Anti: provides an antonym.

2. Able: provides an adjective with the meaning 'being able to ...'

3. Magn: provides an intensifier.

4. Ver: provides an adjective with the meaning 'such as it is supposed to be'

5. Oper ${ }_{1}$ : provides a support, or light, verb (Gross, 1981), which is semantically empty (or at least emptied) in the context of its keyword L. The first DSyntA of this verb (and its SSynt-subject) is the first DSyntA of $\mathrm{L}$, and its second DSyntA (= its main SSynt-object) is L itself.

6. Func $c_{i}$ : also provides a support verb, which is semantically empty. The first DSyntA of this verb (and its SSynt-subject) is $L$ itself. In case of Func, the second DSyntA of the verb (= its main SSynt-object) is the first DSyntA of $L$; in case of Func $c_{0}$, the verb is intransitive.

7. Fact: provides a fulfillment" verb, which expresses the meaning "fulfill the requirements imposed on $L^{\prime}$ [ $=$ ' $L$ does what it is supposed to do']. The requirements differ with respect to different Ls. Thus the requirement of a hypothesis is its confirmation, and the requirement of an illness is death, while the requirement of an artifact is to function according to its design. Syntactically, Fact $0_{0}$ is fully analogous to Funcio and Fact to Func $_{1}$.

8. Incep: Incep, Cont, and Fin (see below) provide what are often called phasal verbs. Thereby, Incep stands for 'begin'.

Naturally, the phasal LFs are often used in complex LFs (see below). Note, however, that they are also applicable to certain verbal key lexemes as simple standard LFs: 


$$
\begin{array}{ll}
\text { Incep }([\text { to }] \text { sleep }) & =[\text { to }] \text { fall asleep } \\
\text { Fin }([\text { to }] \text { sleep }) & =[\text { to }] \text { wake up }
\end{array}
$$

9. Cont: provides a verb with the phasal meaning 'continue'.

10. Fin: provides a verb with the phasal meaning 'cease'.

11. Caus $\left(\right.$ (i) : Caus (and Liqu ${ }_{(i)}$ below) provide causative verbs. Thereby, Caus stands for 'do something so that a situation begins to occur'.

Used with a subscript $i$, Caus (and Liqu) provides a verb that expresses causation of the situation ' $\mathrm{L}$ ' by the $i$-th DSyntA of $\mathrm{L}$. The absence of the subscript indicates causation by an external causer.

12. Liqu: provides a verb with the causative meaning 'liquidate' $[\approx$ 'do something so that a situation stops occurring'].

13. Pred: provides a verb covering the meaning of a copula $+\mathrm{L}$ (i.e. Pred(L) means 'to be an L').

14. Minus: represents the meaning 'less'; this is, so to speak, one of the comparative degrees of Magn. Minus is mostly used in complex LFs, combined with Pred and a phasal verb.

\section{Complex Standard LFs}

The meanings of Complex Standard LFs, LF Configurations and non-standard LFs can easily be derived from the meanings of simple standard LFs discussed above; therefore, we restrict ourselves to a mere enumeration of the former.

$\begin{array}{lll}\text { IncepPredMinus } & \text { Liqu }_{1} \text { Func }_{0} & \text { Caus }_{(2)} \text { Func }_{1} \\ \text { IncepOper }_{1} & \text { IncepFunc }_{1} & \text { CausContFunc }_{1} \\ \text { Caus }_{2} \text { Oper }_{1} & \text { CausFunc }_{1} & \text { Liqu }_{1} \text { Fact }_{0} \\ \text { FinFunc }_{0} & \text { Caus }_{2} \text { Func }_{1} & \text { IncepFact }_{1}\end{array}$

\section{LF Configurations}

$$
\text { Magn + IncepOper } 1 \text { Magn + IncepFunc } \text { I Magn + IncepFact }_{1}
$$

\section{Non-standard LFs}

Magn + fast IncepFunc 1 fast FinFunc f $_{0}$ 


\section{Appendix B: German Data}

\section{Collocational Data}

\subsection{Emotion Lexemes (Keywords)}

$\begin{array}{llll}\text { ACHTUNG } & \text { 'respect' } & \text { MITLEID } & \text { 'compassion' } \\ \text { ANGST } & \text { 'fear' } & \text { NEID } & \text { 'envy' } \\ \text { ARGER } & \text { 'anger' } & \text { PANIK } & \text { 'panic' } \\ \text { AUFREGUNG } & \text { 'excitement' } & \text { REUE } & \text { 'repentance' } \\ \text { BEDAUERN } & \text { 'regret' } & \text { RÜHRUNG } & \text { 'being touched'/ 'moved' } \\ \text { BEGEISIERUNG } & \text { 'enthusiasm' } & \text { SCHADENFREUDE } & \text { 'gloating'/'malicious joy' } \\ \text { EIFERSUCHT } & \text { 'jealousy' } & \text { SCHAM } & \text { 'shame' } \\ \text { EKEL } & \text { 'disgust' } & \text { SCHEU } & \text { 'shyness' } \\ \text { EMPÖRUNG } & \text { 'indignation' } & \text { SCHRECK } & \text { 'terror' } \\ \text { ENTSETZEN } & \text { 'horror' } & \text { STAUNEN } & \text { 'astonishment' } \\ \text { ENTTÄUSCHUNG 'disappointment' TRAUER } & \text { 'sorrow' } \\ \text { ENTZÜCKEN } & \text { 'delight' } & \text { VERACHTUNG } & \text { 'contempt' } \\ \text { ERREGUNG } & \text { 'agitation' } & \text { VERÄRGERUNG } & \text { 'annoyance' } \\ \text { FREUDE } & \text { 'joy' } & \text { VERDRUSS } & \text { 'vexation' } \\ \text { FURCHT } & \text { 'fright' } & \text { VERLEGENHETT } & \text { 'embarrassment' } \\ \text { GROLL } & \text { 'grudge' } & \text { VERWUNDERUNG } & \text { 'amazement' } \\ \text { HASS } & \text { 'hatred' } & \text { VERZWEIFLUNG } & \text { 'despair' } \\ \text { HOFFNUNG } & \text { 'hope' } & \text { WUT } & \text { 'rage' } \\ \text { LEIDENSCHAFT } & \text { 'passion' } & \text { ZORN } & \text { 'wrath' } \\ \text { LIEBE } & \text { 'love' } & \text { ZUNEIGUNG } & \text { 'affection' }\end{array}$

\subsection{Collocate Verbs (=Values of LFs) Studied}

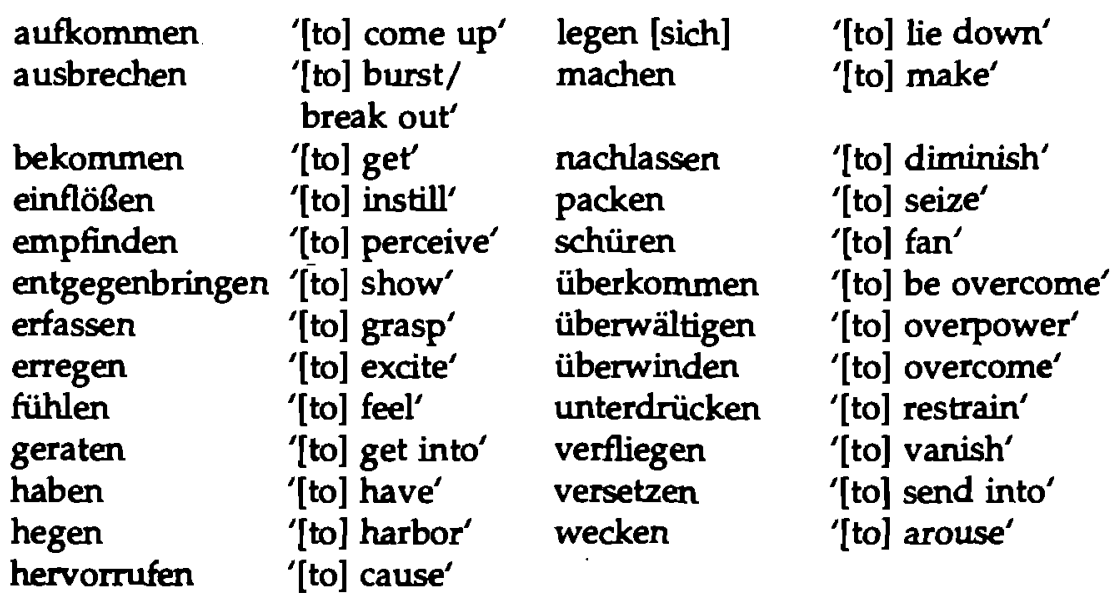




\section{Data on Semantic Dimensions}

\section{Intensity}

Intense' ('+') emotion lexemes:

$\begin{array}{llll}\text { BEGEISTERUNG } & \text { 'enthusiasm' } & \text { PANIK } & \text { 'Panic' } \\ \text { EMPÖRUNG } & \text { 'indignation' } & \text { SCHRECK } & \text { 'terror' } \\ \text { ENTSETZEN } & \text { 'horror' } & \text { STAUNEN } & \text { 'astonishment' } \\ \text { ENTZÜCKEN } & \text { 'delight' } & \text { VERZWEIFLUNG 'despair' } \\ \text { HASS } & \text { 'hatred' } & \text { WUT } & \text { 'rage' } \\ \text { LEIDENSCHAFT } & \text { 'passion' } & \text { ZORN } & \text { 'wrath' } \\ \text { LIEBE } & \text { 'love' } & & \end{array}$

Moderate' emotion lexemes:

VERÄRGERUNG 'annoyance' VERWUNDERUNG 'amazement'
VERDRUSS 'vexation'

The following examples demonstrate the co-occurrence of 'intense' / 'moderate' lexemes with mitigators and intensifiers:

(11) a. Angesichts der randalierenden Rechtsradikalen empfanden die Leute eine "leichte Verzweiflung und Wut

lit. People felt slight despair and rage towards rampaging right extremists'.

vs.

Angesichts des schlechten Wetters empfanden die Spaziergänger eine leichte Enttäuschung.

lit. 'The strollers felt slight disappointment towards foul weather'.

Die brutale Abrechnung der Banditen mit der Familie Nzomocazzo rief in der Beoòlkerung eine *große Verärgerung heroor

lit. 'The bandits' brutal settling of accounts with the family Nzomocazzo caused a big annoyance in the population'. vs.

Die brutale Abrechnung der Banditen mit der Familie Nzomocazzo rief in der Beodtkerung große Empörung hervor

lit. 'The bandits' brutal settling of accounts with the family Nzomocazzo caused a big indignation in the population'.

The label 'moderate' precludes, e.g., the co-occurrence of emotion lexemes with the LF-verbs erfassen '[to] seize', überkommen '[to] overcome', überwältigen '[to] overpower'. The non-'moderate' lexemes co-occur with these verbs, with the 
following distinction: For the 'intense' lexemes, they represent the value of LFS Func $_{1}$ and Fact ${ }_{1}$; for the intensity-neutral lexemes, they are elements of the value of the LF configurations Magn + Func ${ }_{1}$ and Magn + Fact $_{1}$. That is, for not inherently 'intense' lexemes, these verbs add the meaning of high intensity:

Die Angst erfaßte/ überkam/ überwältigte ihn

lit. 'The fear seized/ overcame/ overpowered him'.

(12) obviously implies an 'intense' fear.

\section{Polarity}

The labels 'pleasant' $\left({ }^{\prime}+\right) /$ 'unpleasant' ('-') for emotion lexemes appear here in accordance with, e.g., (Russel 1980). We do not use the more current labels 'positive' and 'negative' (cf., e.g., de Rivera 1977; Dahl and Stengel 1978) since these give rise to a rather unfortunate ambiguity: the 'positive'/ 'negative' perception of the emotion by the Experiencer vs. the 'positive'/ 'negative' actual evaluation of a corresponding emotion by the society.

Thus, e.g., SCHADENFREUDE 'malicious joy' contributes to the improvement of the Experiencer's subjective mental condition and, therefore, should be labeled 'positive' in the first sense. However, in most cultures SCHADENFREUDE is definitely qualified as 'negative' emotion, in the second sense, which means that having this emotion is socially disapproved rather than it being 'negative' for its Experiencer. Inversely, MITLEID 'compassion' is considered a positive emotion in the sense of social approval; however, in terms of perception by the Experiencer, it is 'negative' ('X feels bad'). Compare also:

LEIDENSCHAFT 'passion' of $X$ is semantically 'positive': ' $X$ feels good'. But socially it can be both negative and positive, depending on the situational context:

(13) a. Seine Leidenschaft beim Roulett ist krankhaft (socially negative) lit. 'His passion for the roulette is sickening'.

b. Die Leidenschaft, mit der er die Sache anpackte, imponierte (socially positive)

lit. The passion with which he tackled the task was impressive'.

SCHAM von $X$ 'shame of $X$ ' is semantically 'negative': ' $X$ feels bad'. But socially it can as well be both negative and positive:

(14) a. Die Scham über sein Mißgeschick trug noch weiter zu seiner Unsicherheit bei (socially negative)

lit. The shame for his clumsiness contributed further to his feeling of insecurity'.

Die Scham über das eigene schlechte Benehmen machte Kurt verlegen (socially positive)

lit. 'The shame for his own bad behavior made Kurt feel shy'. 
These examples clearly show the inconvenience of the labels 'positive'/ 'negative'. Therefore, we use unambiguous labels 'pleasant'/ 'unpleasant' (for the Experiencer).

'Pleasant' ('+') emotion lexemes:

$\begin{array}{llll}\text { ACHTUNG } & \text { 'respect' } & \text { LEIDENSCHAFT } & \begin{array}{l}\text { 'passion' } \\ \text { 'love' }\end{array} \\ \text { BEGEISTERUNG } & \text { 'enthusiasm' } & \text { LIEBE } & \text { 'loing touched' } \\ \text { ENTZÜCKEN } & \text { 'delight' } & \text { RÜHRUNG } & \text { 'being } \\ \text { FREUDE } & \text { 'joy' } & \text { SCHADENFREUDE } & \text { 'malicious joy' } \\ \text { HOFFNUNG } & \text { 'hope' } & \text { ZUNEIGUNG } & \text { 'affection' }\end{array}$

'Unpleasant' ( $(-1)$ emotion lexemes:

\begin{tabular}{|c|c|c|c|}
\hline ANGST & 'fear' & PANIK & 'panic' \\
\hline ÄRGER & 'anger' & REUE & 'repentance' \\
\hline AUFREGUNG & 'excitement' & SCHAM & 'shame' \\
\hline BEDAUERN & 'regret' & SCHEU & 'shyness' \\
\hline EIFERSUCHT & 'jealousy' & SCHRECK & 'terror' \\
\hline EKEL & 'disgust' & TRAUER & 'sorrow' \\
\hline EMPÖRUNG & 'indignation' & VERACHTUNG & 'contempt' \\
\hline ENTSETZEN & 'horror' & VERÄRGERUNG & 'annoyance' \\
\hline ENTTÄUSCHUNG & 'disappointment' & VERDRUSS & 'vexation' \\
\hline FURCHT & 'fright' & VERLEGENHEIT & 'embarrassment' \\
\hline GROLL & 'grudge' & VERZWEIFLUNG & 'despair' \\
\hline HASS & 'hatred' & WUT & 'rage' \\
\hline MITLEID & 'compassion'. & ZORN & 'wrath' \\
\hline NEID & 4 & & \\
\hline
\end{tabular}

The above listing demonstrates that the 'unpleasant' emotion lexemes outnumber the 'pleasant' ones almost three to one. This mirrors the fact, well-known in psychology, that human negative (in the psychological sense) emotions are much more numerous than positive ones.

Emotion lexemes that are neither 'pleasant' nor 'unpleasant', i.e. polarityneutral, are ERREGUNG 'agitation', STAUNEN 'astonishment' and VERWUNDERUNG 'amazement'.

As applied to lexical co-occurrence, this dimension contributes to the generalization concerning, e.g., the verb überwinden '[to] overcome' as Liqu ${ }_{1}$ Func 0 : predominantly, it is the 'negative' emotion lexemes that accept it: Verachtung/ Angst/ Eifersucht überwinden '[to] overcome one's contempt/ fear/ jealousy', etc., but not "Achtung/ 'Freude/ 'Leidenschaft überwinden '[to] overcome one's respect/ joy/ passion'. 


\section{Manifestability}

'Manifested' ('+') emotion lexemes:

$\begin{array}{llll}\text { AUFREGUNG } & \text { 'excitement' } & \text { SCHEU } & \text { 'shyness' } \\ \text { BEGEISTERUNG } & \text { 'enthusiasm' } & \text { STAUNEN } & \text { 'astonishment' } \\ \text { ENTSETZEN } & \text { 'horror' } & \text { VERZWEIFLUNG 'despair' } \\ \text { ENTZUCKEN } & \text { 'delight' } & \text { WUT } & \text { 'rage' } \\ \text { FREUDE } & \text { 'joy' } & \text { ZORN } & \text { 'wrath' } \\ \text { PANIK } & \text { 'panic' } & & \end{array}$

Tending-to-be-manifested' ('-') emotion lexemes:

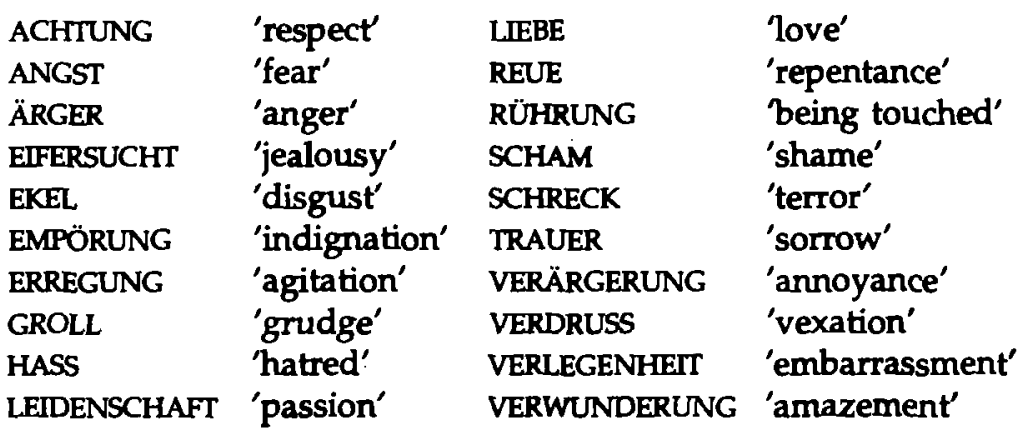

The dimension of manifestability correlates with that of intensity; 'manifested' emotion lexemes are all - with the exception of FREUDE 'joy' and SCHEU 'shyness' - inherently 'intense'. As a consequence, expressions of emotion manifestation imply, as a rule, an 'intense' (or intensified) emotion (they do not co-occur with 'moderate' and mitigated" emotions).

(15) a. Sein Gesicht lief vor Wut rot an

His face turned red from rage'.

vs.

"Sein Gesicht lief vor Verdruß rot an

'His face tumed red from vexation'.

b. Er hüpfte vor Freude

'He jumped from joy'. (Freude means here 'intense joy')

vs.

"Er hüpfte oor etwas Freude

'He jumped from slight joy'.

The dimension of manifestability ensures, e.g., the co-occurrence with the verb ausbrechen '[to] break out' (IncepOper 1 or IncepFunc 1 ): only 'manifested' emotion lexemes take it. Cf. (the first example illustrates the IncepOper ${ }_{1}$ case and the 
second one the IncepFunc $c_{1}$ case):

(16) a. Elke brach in Begeisterung/ Panik/Verzweiflung/Wut/ wilde Freude aus lit. 'Elke burst out in enthusiasm/ panic/ despair/ rage/ wild joy'. vs.

Elke brach in *Bedauern/ *Groll/ *Rührung/ "Verwunderung aus lit. 'Elke burst out in regret/ anger/ emotion/ astonishment'.

b. Im Publikum brach Begeisterung/ Panik/ Verzweiflung/Wut/ wilde Freude aus

lit. 'In the audience, there burst out enthusiasm/ panic/ despair/ rage/ wild joy.'

vs.

Im Publikum brach "Bedauern/ *Groll/ "Rührung/ "Verwunderung aus

lit. 'In the audience, there burst out regret/ anger/ emotion/ astonishment'.

\section{Directionality}

Directed' ('+') emotion lexemes:

$\begin{array}{llll}\text { ACHIUNG } & \text { 'respect' } & \text { LEIDENSCHAFT } & \text { 'passion' } \\ \text { ANGST } & \text { 'fear' } & \text { LIEBE } & \text { 'love' } \\ \text { ARGER } & \text { 'anger' } & \text { MITLEID } & \text { 'compassion' } \\ \text { EIFERSUCHT } & \text { 'jealousy' } & \text { NEID } & \text { 'envy' } \\ \text { EKEL } & \text { 'disgust' } & \text { SCHADENFREUDE } & \text { 'malicious joy' } \\ \text { EMPÖRUNG } & \text { 'indignation' } & \text { VERACHTUNG } & \text { 'contempt' } \\ \text { ENTZÜCKEN } & \text { 'delight' } & \text { VERÄRGERUNG } & \text { 'annoyance' } \\ \text { FURCHT } & \text { 'fright' } & \text { WUT } & \text { 'rage' } \\ \text { GROLL } & \text { 'grudge' } & \text { ZORN } & \text { 'wrath' } \\ \text { HASS } & \text { 'hatred' } & \text { ZUNEIGUNG } & \text { 'affection' }\end{array}$

The semantic dimension of directionality determines the co-occurrence with such verbs as sich richten [gegen $N$ ] '[to] be directed against $N^{\prime}$ and gelten '[to] be valid' (both Func $)_{2}$ : ${ }^{26}$

(17) a. Der Ärger/Groll/ Haß/... der Betroffenen richtet sich gegen die Politiker lit. The anger/ grudge/ hatred/... of those concerned is directed against the politicians'.

Unsere Achtung/Liebe/ Zuneigung/ ... gilt den Mutigen

lit. 'Our respect/ love/ affection ... is valid for the courageous'. 


\title{
5. Mentality
}

'Mental' ('+') emotion lexemes:

\begin{tabular}{|c|c|c|c|}
\hline ACHTUNG & 'respect' & SCHADENFREUDE & 'malicious joy' \\
\hline BEDAUERN & 'regret' & SCHAM & 'shame' \\
\hline EMPÖRUNG & 'indignation' & STAUNEN & 'astonishment' \\
\hline ENTSETZEN & 'horror' & VERACHTUNG & 'contempt' \\
\hline ENTZÜCKEN & 'delight' & VERÄRGERUNG & 'annoyance' \\
\hline FURCHT & 'fright' & VERDRUSS & 'vexation' \\
\hline GROLL & 'grudge' & VERLEGENHEIT & 'embarrassment' \\
\hline HOFFNUNG & 'hope' & VERWUNDERUNG & 'amazement' \\
\hline MITLEID & 'compassion' & VERZWEIFLUNG & 'despair' \\
\hline REUE & 'repentance' & ZORN & 'wrath' \\
\hline RÜHRUNG & 'being touched' & ZUNEIGUNG & 'affection' \\
\hline
\end{tabular}

The dimension of MENTALITY is relevant to the co-occurrence with, e.g., the verb aufkommen '[to] come up': only the emotion lexemes which are not 'mental' take this verb easily (note that in everyday language, this constraint is often violated). Cf.:

\author{
Angst/ Wut/ Ärger/ Freude kam in ihm auf \\ lit. 'Fear/ rage/ anger/ joy came up in him'. \\ vs. \\ ?? Furcht/ 'Zorn/ "Verdruß / "Empörung kam in ihm auf \\ lit. 'Fright/ wrath/ vexation / indignation came up in him'.
}

As we see in this example, there are a few pairs of quasi-synonymous or quasiantonymous lexemes which contrast with respect to absence/ presence of the label 'mental': while ANGST is not 'mental', FURCHT is 'mental', etc.; the members of these pairs also contrast with respect to the co-occurrence with the verb aufkommen '[to] come'.

\section{Reactivity}

'Reactive' ('+') emotion lexemes:

$\begin{array}{llll}\text { ANCST } & \text { 'fear' } & \text { PANIK } & \text { 'panic' } \\ \text { ÄRGER } & \text { 'anger' } & \text { RÜHRUNG } & \text { 'being touched' } \\ \text { EIFERSUCHT } & \text { 'jealousy' } & \text { SCHADENFREUDE 'malicious joy' } \\ \text { EKEL } & \text { 'disgust' } & \text { SCHAM } & \text { 'shame' } \\ \text { EMPÖRUNG } & \text { 'indignation' } & \text { SCHRECK } & \text { 'terror' } \\ \text { ENTSETZEN } & \text { 'horror' } & \text { STAUNEN } & \text { 'astonishment' } \\ \text { ENTTÄUSCHUNG 'disappointment' } & \text { VERÄRGERUNG } & \text { 'annoyance' }\end{array}$




$\begin{array}{llll}\text { ENTZUCCKEN } & \text { 'delight' } & \text { VERDRUSS } & \text { 'vexation' } \\ \text { FREUDE } & \text { 'joy' } & \text { VERZWEIFLUNG } & \text { 'despair' } \\ \text { FURCHT } & \text { 'fright' } & \text { WUT } & \text { 'rage' } \\ \text { GROLL } & \text { 'grudge' } & \text { ZORN } & \text { 'wrath' }\end{array}$

'Reactive' emotion lexemes tend to co-occur, e.g., with the verb erregen '[to] excite':

\section{Sein Benehmen errregte Vaters Zorn/Staunen/ Eifersucht/ Ekel}

lit. 'His behavior excited father's wrath/ astonishment/ jealousy/ disgust'.

There are, however, some exceptions:

(20) Sein Benehmen erregte Vaters "Empörung/ *ihre Scham/ "meine Verzweiflung

lit. 'His behavior excited father's indignation/ her shame/ my despair'.

This dimension correlates with the dimension of ATTIUDINALTTY, see immediately below: all 'attitudinal' emotion lexemes are 'reactivity-neutral'.

\section{Attitudinality}

'Attitudinal' ('+') emotion lexemes:

$\begin{array}{llll}\text { ACHTUNG } & \text { 'respect' } & \text { MTTLEID } & \text { 'compassion' } \\ \text { HASS } & \text { 'hatred' } & \text { VERACHTUNG } & \text { 'contempt' } \\ \text { LIEBE } & \text { 'love' } & \text { ZUNEIGUNG } & \text { 'affection' }\end{array}$

Only 'attitudinal' emotion lexemes co-occur with the verb entgegenbringen '[to] show':

(21) Sie bringt ihm selbstlose Liebe entgegen

lit. 'She shows him selfless love'.

vs.

* Sie bringt ihm eine wilde Eifersucht entgegen

lit. 'She shows him a wild jealousy'.

In order to account for the co-occurrence of some LF verbs with the governed prepositions, attitudinals should be further characterized by the labels 'approving'/ 'disapproving'. ACHTUNG 'respect', LIEBE 'love', MITLEID 'compassion', and ZUNEIGUNG 'affection' denote an 'approving' attitude, while HASS 'hatred' and verACHTUNG 'contempt' - a 'disapproving' attitude. Cf. the co-occurrence with the verb hegen '[to] harbor': 
(22)
Er hegt für $<^{*}$ gegen> Elke eine tiefe Achtung/ zärtliche Liebe/ besondere Zuneigung
lit. 'He harbors for <against> Elke a deep respect/ a tender love/ a special inclination'.
vs.
Er hegt gegen <*für> Hugo eine tiefe Verachtung/ einen abgrundtiefen Haß lit. 'He harbors against <for> Elke a deep contempt/ a profound hatred'.

In the present study, we do not consider the labels 'approving'/ 'disapproving'.

\section{Activity}

'Active' ('+') emotion lexemes:

\begin{tabular}{|c|c|c|c|}
\hline $\begin{array}{l}\text { ACHIUNG } \\
\text { ANGST }\end{array}$ & $\begin{array}{l}\text { 'respect' } \\
\text { 'fear' }\end{array}$ & $\begin{array}{l}\text { RÜHRUNG } \\
\text { SCHAM }\end{array}$ & $\begin{array}{l}\text { 'being touched' } \\
\text { 'shame' }\end{array}$ \\
\hline BEGEISTERUNG & 'enthusiasm' & SCHEU & 'shyness' \\
\hline EKEL & 'disgust' & SCHRECK & 'terror' \\
\hline ENTSETZEN & 'horror' & VERACHTUNG & 'contempt' \\
\hline FREUDE & 'joy' & VERLEGENHETT & 'embarrassment' \\
\hline FURCHT & 'fright' & VERZWEIFLUNG & 'despair’ \\
\hline HASS & 'hatred' & WUT & 'rage' \\
\hline LEIDENSCHAFT & 'passion' & ZORN & 'wrath' \\
\hline MTLEID & ompassion' & ZUNEIGUNG & 'affection' \\
\hline PANIK & anic' & & \\
\hline
\end{tabular}

'Active' emotion lexemes (which are mostly not 'pleasant') co-occur with the verb überwinden '[to] overcome' (as a value of Liqu $_{1}$ Func $_{0}$ ):

(23) Sie konnte ihre Scheu/ ihr Entsetzen/ ihre Panik überwinden lit. 'She could overcome her shyness/ her terror/ her panic'. vs.

Sie konnte ihr "Bedauern/ ihre *Reue/ ihr *Staunen nicht überwinden lit. 'She could not overcome her regret/ her repentance/ her astonishment'.

Most of the 'active' emotion lexemes are also 'manifested' and vice versa. However natural, this correlation is not obligatory: thus, ACHTUNG 'respect' is 'active' but not 'manifested', while AUFREGUNG 'excitement' is 'manifested' but not 'active'. 


\section{Excitation}

'Excited-state' ('+') emotion lexemes:

$\begin{array}{llll}\text { ANGST } & \text { 'fear' } & \text { LEIDENSCHAFT } & \begin{array}{l}\text { 'passion' } \\ \text { 'love' }\end{array} \\ \text { ÄRGER } & \text { 'anger' } & \text { LIEBE } & \text { ''panic' } \\ \text { AUUREGUNG } & \text { 'excitement' } & \text { PANIK } & \text { 'being touched' } \\ \text { BEGEISTERUNG } & \text { 'enthusiasm' } & \text { RÜHRUNG } & \text { 'malious joy' } \\ \text { EIFERSUCHT } & \text { 'jealousy' } & \text { SCHADENFREUDE } & \text { 'malicious } \\ \text { EMPÖRUNG } & \text { 'indignation' } & \text { SCHRECK } & \text { 'terror' } \\ \text { ENTSETZEN } & \text { 'horror' } & \text { VERÄRGERUNG } & \text { 'annoyance' } \\ \text { ENTZÜCKEN } & \text { 'delight' } & \text { VERDRUSS } & \text { 'vexation' } \\ \text { ERREGUNG } & \text { 'excitation' } & \text { VERZWEIFLUNG } & \text { 'despair' } \\ \text { FREUDE } & \text { 'joy' } & \text { WUT } & \text { 'rage' } \\ \text { FURCHT } & \text { 'fright' } & \text { ZORN } & \text { 'wrath' }\end{array}$

'Excited-state' emotion lexemes (except ENTZÜCKEN 'delight', RÜHRUNG 'being touched', SCHADENFREUDE 'malicious joy' and VERDRUSS 'vexation') co-occur with the verb sich legen '[to] subside' (as a value of FinFunc ) $^{\text {): }}$

(24) Ihre Angst/ Begeisterung/ Eifersucht/ Panik legte sich lit. 'Her fear/ excitement/ jealousy/ panic subsided'. vs.

Ihre *Achtung/ ihr *Bedauern/ ihre *Reue/ ihre *Zuneigung legte sich lit. 'Her respect/ regret/ repentance/ affection subsided'.

\section{Self-control}

'Self-control-loss-inflicting' (' + ') emotion lexemes:

$\begin{array}{llll}\text { ANGST } & \text { 'fear' } & \text { LEIDENSCHAFT } & \text { 'passion' } \\ \text { BEGEISTERUNG } & \text { 'enthusiasm' } & \text { PANIK } & \text { 'panic' } \\ \text { EIFERSUCHT } & \text { 'jealousy' } & \text { SCHRECK } & \text { 'terror' } \\ \text { ENTSETZEN } & \text { 'horror' } & \text { VERZWEIFLUNG } & \text { 'despair' } \\ \text { FREUDE } & \text { 'joy' } & \text { WUT } & \text { 'rage' } \\ \text { HASS } & \text { 'hatred' } & \text { ZORN } & \text { 'wrath' }\end{array}$

'Self-control-loss-inflicting' lexemes co-occur with the verb überkommen '[to] overcome' (as a value of IncepFact $t_{1}$ ):

(25) Ihn überkam eine wilde Panik

lit. 'A wild panic overcame him'.

vs.

*Ihn überkam eine tiefe. Achtung zu seinem Lehrer

lit. 'A deep respect to his teacher overcame him'. 
11. Permanence

'Permanent' ('+') emotion lexemes:

$\begin{array}{llll}\text { ACHTUNG } & \text { 'respect' } & \text { LEIDENSCHAFT } & \text { 'passion' } \\ \text { ANGST } & \text { 'fear' } & \text { LIEBE } & \text { 'love' } \\ \text { BEDAUERN } & \text { 'regret' } & \text { MTTLEID } & \text { 'compassion' } \\ \text { EIFERSUCHT } & \text { 'jealousy' } & \text { NEID } & \text { 'envy' } \\ \text { EKEL } & \text { 'disgust' } & \text { REUE } & \text { 'repentance' } \\ \text { FREUDE } & \text { 'joy' } & \text { SCHAM } & \text { 'shame' } \\ \text { FURCHT } & \text { 'fright' } & \text { SCHEU } & \text { 'shyness' } \\ \text { GROLL } & \text { 'grudge' } & \text { TRAUER } & \text { 'sorrow' } \\ \text { HASS } & \text { 'hatred' } & \text { VERACHTUNG } & \text { 'contempt' } \\ \text { HOFFNUNG } & \text { 'hope' } & \text { ZUNEIGUNG } & \text { 'affection' }\end{array}$

'Permanent' or 'temporary' (' \pm ') emotion lexemes:

$\begin{array}{llll}\text { ANGST } & \text { 'fear' } & \text { GROLL } & \text { 'grudge' } \\ \text { BEDAUERN } & \text { 'regret' } & \text { REUE } & \text { 'repentance' } \\ \text { EKEL } & \text { 'disgust' } & \text { SCHAM } & \text { 'shame' } \\ \text { FREUDE } & \text { 'joy' } & \text { SCHEU } & \text { 'shyness' } \\ \text { FURCHT } & \text { 'fright' } & & \end{array}$

'Permanent' emotion lexemes do not co-occur with the verb geraten '[to] get into' (IncepOper ${ }_{1}$ ); they tend to co-occur (although with many exceptions) with the verb haben '[to] have' (Oper 1$)$ :

(26) a. "Hans geriet in Achtung vor seinem Lehrer lit. 'Hans got into respect to his teacher'. vs.

Hans hatte eine tiefe Achtung vor seinem Lehrer lit. 'Hans had a deep respect to his teacher'.

b. Dieser Mann geriet in Hass gegen alles Fremde

lit. 'This man got into hatred against everything foreign'. vs.

Dieser Mann hatte einen abgrundtiefen Hass gegen alles Fremde lit. 'This man had a deep hatred against everything foreign'.

'Temporary' emotion lexemes show a clear preference for the co-occurrence with the verb sich legen '[to] subside' (just as 'excited state' lexemes) and verfliegen '[to] vanish': 
(27) a. Die Aufregung legte sich

lit. 'The excitement subsided'.

vs.

?Der Haß legte sich

lit. 'The hatred subsided'.

Emotion lexemes that can be either 'permanent' or 'temporary' behave heterogeneously with respect to the co-occurrence with geraten '[to] get into'; thus, SCHEU 'shyness', SCHAM 'shame', and FURCHT 'fright' do not co-occur with it, but ANGST 'fear' and FREUDE 'joy' do.

All 'permanent' or 'temporary' lexemes (with exception of REUE 'repentance') co-occur with haben '[to] have':

(28) a. Elke hatte Angst/einen Ekel/ eine große Furcht/ eine unerklärliche Scheu vor ihm

lit. Elke had fear/a disgust/ a big fright/ an unexplainable shyness with respect to him'.

b. Levin hatte eine große Freude an dem Traktor

lit. 'Levin had a big joy with respect to the tractor'.

The expression Scham haben '[to] have shame' is an idiom; most often it is used either in such questions as: Hast Du keine Scham? lit. 'Don't you have any shame?' or in statements such as Er hat keine Scham im Leibe lit. 'He has no shame in the body'.

\section{Data on Restricted Lexical Co-occurrence}

To be able to generalize restricted lexical co-occurrence over emotion lexemes, we need plausible correlations between semantic components (i.e. values of semantic dimensions), introduced in Section, and LF values as shown in Figure 2, i.e. the twenty-five verbs chosen for the investigation (see Appendix B, Section 4). In the following, we briefly review these verbs with respect to their interdependencies with the semantic components of the emotion lexeme definitions.

Aufkommen '[to] come up'

Aufkommen as a value of the $\mathrm{LF}$ IncepFunc $\mathrm{C}_{1}$ co-occurs with thirty-five of our emotion lexemes. The exceptions - entzücken 'delight', LEIDENSCHAFT 'passion', LIEBE 'love', SCHEU 'shyness', and SCHRECK 'terror' - are, however, not easily generalizable. Therefore, their incompatibility is specified explicitly in the entries of these five lexemes. 
Ausbrechen '[to] burst/ break out'

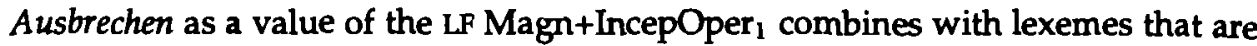
simultaneously 'intense' and 'manifested': in Begeisterung/ Panik ausbrechen '[to] burst out in enthusiasm/ panic'; cf. in "Freude ausbrechen '[to] burst out in joy' [FREUDE is not intense; cf. in wilde Freude ausbrechen '[to] burst out in wild joy']; in brennende "Eifersucht ausbrechen '[to] burst out in burning jealousy' [EIFERSUCHT is not manifested]. Three exceptions are found: ENISETZEN 'horror', ENTZÜCKEN 'delight', and STAUNEN 'astonishment', which are 'intense' and 'manifested' but do not co-occur with ausbrechen. Again, these exceptions are individually specified. ${ }^{27}$

\section{Bekommen '[to] get'}

We could not find a clear correspondence between values of our semantic dimensions and the co-occurrence of bekommen as a value of the LF IncepOper ${ }_{1}$. Eleven - out of the forty - lexemes co-occur with it: ACHTUNG 'respect', ANGST 'fear', EKEL 'disgust', HASS 'hatred', HOFFNUNG 'hope', MITLEID 'compassion', PANIK 'panic', SCHEU 'shyness', SCHRECK 'terror', wUT 'rage', and ZORN 'wrath' ${ }^{28}$ All of them are 'active'; there are, however, also 'active' lexemes (e.g., BEGEISTERUNG 'enthusiasm', LEIDENSCHAFT 'passion', VERLEGENHEIT 'embarrassment') that do not co-occur with bekommen. The co-occurrence of FURCHT 'fright' with bekommen has been questioned. Therefore, we list all occurrences of bekommen explicitly in the corresponding entries. ${ }^{29}$

\section{Einflößen '[to] instill'}

Only few lexemes of a rather heterogeneous nature accept einflößen as a value of the LF Caus Func $_{1}$ : ACHTUNG 'respect', ANGST 'fear', FURCHT 'fright', HOFFNUNG 'hope', and MITLEID 'compassion'.

Due to the semantic heterogeneity of these emotion lexemes and their small number, we list their co-occurrence with einflößen explicitly. Nevertheless, there are semantic features which are presupposed by this co-occurrence: literally, einflößen ('Ito] infuse', 'Ito] instill') describes a slow continuous injection. Hence, emotion lexemes that co-occur with it must not be "punctual": einen "Schreck/ "Entzücken einflößen '[to] instill terror/ delight'. ${ }^{30}$

Empfinden '[to] perceive'

Empfinden as a value of Oper ${ }_{1}$ is the most current choice among other expressions of Oper, for emotion lexemes: it combines with thirty-five out of the forty lexemes under consideration. The lexemes with which it does not co-occur - AUFREGUNG 'excitement', ENIZÜCKEN 'delight', PANIK 'panic', STAUNEN 'astonishment', and VERWUNDERUNG 'amazement' - do not form a semantic subclass; we consider them as lexical exceptions and indicate this explicitly in their entries. 
Entgegenbringen '[to] show'

Entgegenbringen as a value of Oper 1 co-occurs with 'attitudinal' emotion lexemes: Achtung/ Liebe/ Mitleid / ... entgegenbringen 'Ito] show respect/ love/ compassion'.

Erfassen '[to] grasp'

Erfassen as a value of Magn + IncepFunc $c_{1}$ co-occurs, in general, with 'intense' and 'intensity-neutral' emotion lexemes. Some of the 'intensity-neutral' lexemes require an intensifier in order to co-occur with erfassen: "Verlegenheit erfaßte ihn 'Embarrassment grasped him', but eine starke Verlegenheit erfaßte ihn lit. 'A strong embarrassment grasped him'. Erfassen does not co-occur with 'moderate' emotion lexemes: "Verärgerung / "Verdruß / "Verwunderung erfaßte ihn 'Annoyance/ Vexation/ Amazement grasped him' and, exceptionally, with a few of the 'intense', and 'intensity-neutral' lexemes (e.g., ÄRGER 'anger', ENTZÜCKEN 'delight', HOFFNUNG 'hope', etc.), which is stated explicitly.

Erregen '[to] excite'

Erregen as a value of Caus Func $_{1}$ tends to co-occur (although with exceptions) with emotion lexemes that are 'reactive': Empörung/ Furcht/ Zorn erregen '[to] excite indignation/ fright/ wrath'. However, there are counterexamples: some 'reactive' lexemes do not accept erregen ("Entsetzen/ Entzücken erregen '[to] excite horror/ delight), while HASS 'hatred' and NEID 'envy', which are 'reactivity-neutral' do.

Despite these counterexamples, however, the co-occurrence behavior of erregen still allows a generalization (for 'reactive' lexemes). The exceptions and the co-occurrence with lexemes that do not have these semantic features are listed explicitly in the corresponding lexical entries.

Fühlen '[to] fill'

Although fühlen as a value of Oper $_{1}$ is synonymous to empfinden, the co-occurrence behavior of these two verbs is not identical: fühlen is accepted only by a subset of emotion lexemes that co-occur with empfinden. Thus, while EMPÖRUNG 'indignation', ENTSETZEN 'horror', REUE 'repentance' etc. co-occur with empfinden, they do not with fühlen.

We could not find valid semantic reasons for this type of deviation, and, therefore, note this co-occurrence explicitly: since more than twenty of the emotion lexemes co-occur with fizhlen, we specify only the non-occurrence.

Geraten '[to] get into'

Geraten as a value of Magn + IncepOper ${ }_{1}$ does not co-occur with 'permanent' emotion lexemes; a number of 'temporary' lexemes (e.g., ÄRGER 'anger', ENTTÄUSCHUNG 'disappointment', RÜHRUNG 'being touched', etc.), however, also 
do not occur with it. In general, geraten co-occurs with emotion lexemes that are 'manifested'; and additionally with ERREGUNG 'agitation' and VERLEGENHEIT 'embarrassment'. There are also some exceptions: although ENISETZEN 'horror' is 'manifested', it does not co-occur with geraten. ${ }^{31}$ A further exception is SCHEU 'shyness'.

\section{Haben '[to] have'}

Haben as a value of Oper ${ }_{1}$ co-occurs with the most lexemes that are 'permanent'; the exceptions here are EIFERSUCHT 'jealousy', LIEBE' 'love', NEID 'envy', REUE 'repentance', and TRAUER 'sorrow'. Further, two temporary lexemes WUT 'rage', and ZORN 'wrath' also co-occur with haben. ${ }^{32}$

Hegen '[to] harbor'

Hegen as a value of Oper 1 , co-occurs only with six emotion lexemes: ACHTUNG 'respect', GROLL 'grudge', HASS 'hatred', HOFFNUNG 'hope', LEIDENSCHAFT 'passion', and ZUNEIGUNG 'affection'. For these lexemes no semantic generalization seems possible. Thus, we list the co-occurrence with hegen explicitly.

\section{Hervorrufen '[to] cause'}

Heroorrufen as a value of Caus $_{2}$ Func $_{1}$ co-occurs with the most emotion lexemes. Those which do not accept it include ACHTUNG 'respect', EIFERSUCHT 'jealousy', and HOFFNUNG 'hope', etc. These exceptions are stated explicitly.

Legen [sich] '[to] lie down'

Sich legen as a value of FinFunc $c_{0}$ co-occurs, in principle, with 'excited-state' lexemes, with the exception of ENTZÜCKEN 'delight', LIEBE 'love', and SCHADENFREUDE 'malicious joy'.

In addition, it co-occurs with five lexemes that do not denote 'excited-state' emotions: ENTTÄUSCHUNG 'disappointment', GROLL 'grudge', SCHEU 'shyness', STAUNEN 'astonishment', and VERLEGENHEIT 'embarrassment'.

Machen '[to] make'

Only four emotion lexemes co-occur with machen as a value of $\operatorname{Caus}_{(2)} F_{u n c_{1}}$ : ANGST 'fear', FREUDE 'joy', HOFFNUNG 'hope', and VERDRUSS 'vexation'. No generalization seems possible; therefore, this co-occurrence is specified explicitly in the entries of the above lexemes. ${ }^{33}$

Nachlassen '[to] diminish'

Nachlassen as a value of IncepPredMinus co-occurs with all the 'excited-state' 
emotion lexemes with the exception of ENTZÜCKEN 'delight', RÜHRUNG 'being touched', SCHADENFREUDE 'malicious joy', and VERDRUSS 'grudge'. There are also several lexemes that co-occur with nachlassen without denoting 'excited-state' emotions: for example, ENTTÄUSCHUNG 'disappointment', HOFFNUNG 'hope', and MITLEID 'compassion'.

\section{Packen '[to] seize'}

The co-occurrence with packen as a value of Magn + fast IncepFunc I $_{1}$ characterizes 'self-control-loss-inflicting' emotion lexemes: Begeisterung/ Leidenschaft/ Ensetzen packten ihn 'Enthusiasm/ Passion/ Horror seized him'. It also presupposes high intensity: the additional three lexemes that - without being 'self-control-lossinflicting' - can co-occur with packen (ERREGUNG 'agitation', REUE 'repentance', STAUNEN 'astonishment') must then have explicit intensifiers: Eine tiefe Reue packte ihn lit. 'deep repentance seized him', but not ?? die Reue packte ihn '(The) repentance seized him'.

\section{Schüren '[to] fan'}

Schüren as a value of CausContFunc $c_{1}$ expresses a disapproval of the emotion in question by the speaker. Therefore, it is natural for it to co-occur mostly with 'unpleasant' emotion lexemes (e.g., ANGST 'fear', EIFERSUCHT 'jealousy', GROLL 'grudge', etc.). However, it can also co-occur with 'pleasant' emotion lexemes (in the emotion field this is LEIDENSCHAFT 'passion': eine krankhafte Leidenschaft schüren '[to] fan a sick passion', where schüren implies that the speaker strongly disapproves of the passion - although it could be very pleasant for the Experiencer.

Since the subset of 'unpleasant' lexemes that co-occur with schüren is considerably smaller than the subset of those which do not $(10: 17)$, we list this cooccurrence explicitly.

\section{Überkommen '[to] overcome'}

Überkommen as a value of Magn + IncepFact ${ }_{1}$ co-occurs with the majority of the forty emotion lexemes. Similar to erfassen '[to] grasp', however, it does not cooccur with 'moderate' lexemes: "Verärgerung/ "Verdruß/ *Verwunderung überkam sie 'He was overcome by annoyance/ grudge/ amazement'. Further lexemes which überkommen does not go with include, for example, ACHTUNG 'respect', LIEBE 'love', and VERACHTUNG 'contempt': "Achtung/ "Liebe/ "Verachtung überkam ihn 'He was overcome by respect/ love/ contempt'. However, this cannot be properly captured in terms of our semantic features. Therefore, we mark explicitly the lexemes which do not co-occur with überkommen. 


\section{Überwältigen '[to] overpower'}

Überwältigen as an another value of Magn + IncepFact ${ }_{1}$ co-occurs with a subset of lexemes that co-occur with überkommen '[to] overcome': e.g., unlike überkommen, the verb überwaltigen does not co-occur with EKEL 'disgust'; it also does not go as easily with ENTTÄUSCHUNG 'disappointment' as überkommen does.

Note that co-occurrence with überwältigen caused serious disagreement among our informants. Since only twelve lexemes co-occur with überwailtigen, we list this co-occurrence explicitly.

\section{Überwinden '[to] overcome'}

Überwinden as a value of Liqu ${ }_{1}$ Func $_{0}$ tends to co-occur with 'unpleasant' emotion lexemes: seine Angst/ Eifersucht/ Scheu überwinden '[to] overcome one's fear/ jealousy/ shyness'; but not seine *Achtung/ "Hoffnung/ überwinden '[to] overcome one's respect/ hope.

However, this is not a generally valid rule: depending on the context, überwinden can readily co-occur with 'pleasant' emotion lexemes if the emotion referred to incites the Experiencer to do something he or she does not want to:

(32) a. Hans überwand seine Begeisterung und ging endlich zur Schule lit. 'Hans overcame his enthusiasm and went to school, finally'.

b. Die Schadenfreude zu überwinden und zu helfen ... lit. 'To overcome the malicious joy and to help ...'.

Further, there is a small subgroup of 'unpleasant' emotion lexemes whose cooccurrence with überwinden has been questioned by the major part of the subjects. These are mainly those lexemes which are 'mental', e.g., BEDAUERN 'regret', STAUNEN 'astonishment', VERDRUSS 'grudge', etc.: sein 'Bedauern/ 'Staunen/ 'Verdruß überwinden '[to] overcome one's regret/ astonishment/ vexation'.

Finally, überwinden does not easily co-occur with 'moderate' lexemes: seine 'Verärgerung/seinen 'Verdruß/seine 'Verwunderung überwinden '[to] overcome one's annoyance/ vexation/ amazement'.

All in all, überwinden co-occurs with thirty out of the forty emotion lexemes, therefore, it is specified in the field subentry of GEFÜHL 'emotion' with the exceptions listed explicitly.

\section{Unterdrücken '[to] restrain'}

Unterdrücken as a value of the LF Liqu Fact $_{0}$ naturally co-occurs with 'excited-state' emotion lexemes: Er unterdrückte seine Angst/seinen Ärger/ seine Empörung lit. 'He restrained his fear/ his anger/ his indignation'. Only two 'excitation-state' lexemes do not take it: SCHRECK 'terror' and VERZWEIFLUNG 'despair'. However, some 'excitation-neutral' lexemes also co-occur with unterdrücken: Er unterdrückte seine Enttäuschung/seinen Groll/ seinen Haß lit. 'He restrained his disappointment/ his 
grudge/ his hatred'.

Further, like überwinden '[to] overcome', unterdrïcken also presupposes the emotion to be 'unpleasant': seine Eifersucht unterdrücken [to] restrain one's jealousy'; but not seine *Hoffnung unterdrücken '[to] restrain one's hope'.

In contrast to überwinden '[to] overcome', however, unterdrücken also cooccurs with the lexemes which denote emotions that, without being unpleasant for the speaker, may be negatively reacted at by the environment, so that this could be disadvantageous to the Experiencer:

(33) a. Der Schüler unterdrückte seine Schadenfreude als er den auf dem Boden liegenden Lehrer sah

lit. The student restrained his malicious joy when he saw the teacher lying on the floor'.

b. Maria unterdrückte ihr Mitleid und ging vorbei

lit. 'Maria restrained her compassion and passed'.

c. Hans unterdrückte seine Freude

lit. 'Hans restrained his joy'.

The above examples are acceptable, although SCHADENFREUDE 'malicious joy' and FREUDE ' $j 0 y$ ' are considered as being positive from the Experiencer's perspective in Subsection 3.1. As in the case of überwinden '[to] overcome', the co-occurrence with unterdricken is described as acceptable for the whole field of emotion lexemes; the exceptions are again stated explicitly.

\section{Verfliegen '[to] vanish'}

Verfliegen as a value of fast Finfunco must, intuitively, have a co-occurrence behavior similar to that of sich legen '[to] lay down'. Indeed, verfliegen also shows a preference for 'excited-state' emotion lexemes, exceptions being ENTSETZEN 'horror', ENTZÜCKEN 'delight', LIEBE 'love', and PANIK 'panic'. Non-'excited-state' lexemes that co-occur with verfliegen include ENTTÄUSCHUNG 'disappointment', GROLL 'grudge', and HOFFNUNG 'hope'. However, a comparison with sich legen shows many differences: thus, sich legen, but not verfliegen combines with ENTSETZEN 'horror', while verfliegen, but not sich legen accepts HOFFNUNG 'hope'; etc.

\section{Versetzen '[to] send into'}

Versetzen as a value of $\mathrm{Caus}_{2} \mathrm{Oper}_{1}$ co-occurs predominantly either with 'intense' lexemes or 'intensity-neutral' lexemes that explicitly or implicitly express high intensity: in Angst/ Aufregung/ Begeisterung versetzen '[to] send into fear/ excitement/ enthusiasm'. There are, however, too many exceptions and too few lexemes that co-occur with versetzen for a generalization to be possible. Therefore, we list all of its co-occurrence explicitly. 
Wecken '[to] arouse'

Wecken as a value of CausFunc 1 co-occurs with twelve of the forty emotion lexemes: e.g., Angst/ Bedauern/ Begeisterung wecken '[to] arouse fear/ regret/ enthusiasm'. The semantic characteristics of these lexemes are, however, divergent to such an extent that no useful generalization seems to be possible. 
Appendix C: Abridged Generalized Lexical Entries of Forty Emotion Lexemes in German

1. ACHTUNG, fem Achtung von $X$ vor $Y$ wegen $Z$ ' $X$ 's respect towards $Y$ because of $Z$ ' = $X$ 's pleasant, manifestable, mental, attitudinal, active, approving, permanent Gefühl directed at $Y$ because of $Z$

$$
\begin{array}{|l|}
\hline \mathrm{Y}=\mathrm{II} \\
\hline \text { 1. vor } \mathrm{N}_{d a t} \\
\hline
\end{array}
$$

†Oper 1

IncepOper 1

Magn + IncepOper 1

$\uparrow_{\text {Caus }}$ Func $_{1}$

Magn + IncepFact

Liqu $_{1}$ Fact $_{0}$
: hegen [für $\left.\mathrm{N}_{\text {acc }} \sim_{\text {acc }}\right]$

: bekommen $\left[\sim_{a c c}\right]$

: ᄀerfassen

: einflößen $\left[\mathbf{N}_{d a t} \sim a c c\right]$ I DSyntA I is a predicate $\neg$ hervorrufen

: ᄀüberkommen

: ᄀunterdrücken

2. ANGST, fem

Angst von $X$ vor $Y$ wegen $Z$ ' $X$ 's fear of $Y$ because of $Z$ ' $=X$ 's unpleasant, manifestable, reactive, active, excited-state, self-controlloss-inflicting, permanent or temporary Gefühl directed at $Y$

$$
\begin{array}{|l|}
\hline \mathrm{Y}=\mathrm{II} \\
\hline \text { 1. vor } \mathrm{N}_{\text {dat }} \\
\text { 2. } z u \mathrm{~V}_{\text {inf }} \\
\text { 3. daß PROP }
\end{array}
$$

IncepOper

$\mathrm{Caus}_{2} \mathrm{Oper}_{1}$

CausContFunc $_{1}$

$\uparrow$ Caus $_{2}$ Func $_{1}$

Caus $_{(2)}$ Func $_{1}$
: bekommen [ $\left.\sim_{a c c}\right]$

: versetzen $\left[\mathrm{N}_{\text {acc }}\right.$ in -acc]

: schüren [in $\mathrm{N}_{\text {dat }} \sim$ acc]

: einflößen $\left[\mathrm{N}_{\text {dat }} \sim\right.$ accl, erregen, wecken [in $\mathrm{N}_{\text {dat }} \sim_{\text {acc }}$ ]

: machen $\left[\mathbf{N}_{\text {dat }}\right.$ - acc $]$

3. ÄRGER, masc

Ärger von $X$ über $Y$ wegen $Z$ 'X's anger at $Y$ because of $Z$ ' = X's unpleasant, manifestable, reactive, excited-state, temporary Gefühl directed at $Y$ 
$\begin{array}{lll}\text { Toper }_{1} & : & \text { fühlen } \\ \text { Magn + IncepFunc }_{1} & : & \text { चerfassen } \\ \text { Magn + IncepFact }_{1} & : & \text { चüberkommen }\end{array}$

4. AUFREGUNG, fem

Aufregung von $X$ wegen $Y$ ' $X$ 's agitation because of $Y^{\prime}=X^{\prime} s$ unpleasant, manifested, excited-state, temporary Gefühl caused by $Y$

Oper $_{1}$

$\mathrm{Caus}_{2} \mathrm{Oper}_{1}$

Liqu $_{1}$ Func $_{0}$

: ᄀempfinden, $\neg$ fühlen

: - Jüberwinden

Magn + IncepFunc 1 : ᄀerfassen

Magn + IncepFact 1 : ᄀüberkommen

5. BEDAUERN, neut

Bedauern von $X$ über $Y$ wegen $Z$ ' $X$ 's regret towards $Y$ because of $Z$ ' = $X$ 's unpleasant, mental, permanent or temporary Gefühl towards $Y$ because of $Z$

$\uparrow$ Caus $_{2}$ Func $_{1}$

Liqu $_{1}$ Func $_{0}$

: wecken [in $\mathrm{N}_{\text {dat }}$-acc],

Liqu $_{1}$ Fact $_{0}$

: ' ᄀüberwinden

: ᄀunterdrücken

6. BEGEISTERUNG, fem

Begeisterung von $X$ über $Y$ ' $X$ 's enthusiasm caused by $Y^{\prime}=X^{\prime}$ 's intense, pleasant, manifested, active, excited-state, self-control-loss-inflicting, temporary Gefühl caused by $\mathrm{Y}^{34}$

$\mathrm{Y}=\mathrm{II}$

1. über $\mathrm{N}_{a c c}$

2. darüber, daß PROP

Oper $_{1}$

Caus $_{2}$ Oper $_{1}$

$\uparrow$ Caus $_{2}$ Func $_{1}$

: 'fühlen

: versetzen $\left[\mathrm{N}_{\text {acc }}\right.$ in $\left.\sim a c c\right]$

Magn + IncepFact ${ }_{1}$

: wecken [in $\mathrm{N}_{\text {dat }} \sim$ acc]

: überwältigen $\left[\mathrm{N}_{a c c}\right]$

7. EIFERSUCHT, fem

Eifersucht von $X$ auf $Y$ wegen $Z$ ' $X$ 's jealousy towards $Y$ because of $Z$ ' = $X^{\prime}$ 's unpleasant, manifestable, reactive, excited-state, permanent Gefühl directed at $Y$ 


$$
\begin{array}{|l|}
\hline \mathrm{Y}=\mathrm{II} \\
\hline \text { 1. auf } \mathrm{N}_{a x c} \\
\hline
\end{array}
$$

Oper $_{1}$

$\uparrow$ Caus $_{2}$ Func $_{1}$

: Thaben

CausContFunc 1

: wecken [in $\mathrm{N}_{d a t} \sim a c c$ ], $\neg$ hervorrufen

: schüren [in $\mathrm{N}_{d a t} \sim a c c$ ]

8. EKEL, masc

Ekel von $X$ oor $Y$ wegen $Z$ ' $X$ 's disgust of $Y$ because of $Z$ ' $=X$ 's unpleasant, manifestable, reactive, active, permanent or temporary Gefühl caused by and directed at $Y$ because of $Z$

$$
\begin{aligned}
& \mathrm{Y}=\mathrm{II} \\
& \text { 1. vor } \mathrm{N}_{a c c} \\
& \text { 2. davor, daß PROP }
\end{aligned}
$$

IncepOper 1

9. EMPÖRUNG, fem

Empörung oon $X$ über $Y$ wegen $Z$ ' $X$ 's indignation at $Y$ ' $=X$ 's intense, unpleasant, manifestable, mental, reactive, excited-state, temporary Gefühl caused by $Y^{\prime} Z$ and directed at $Y$

Oper 1

CausContFunc $_{1}$

: ᄀfühlen

: schüren [in $\mathrm{N}_{d a t} \sim a c c$ ]

10. ENTSETZEN, neut

Entsetzen von $X$ über $Y$ ' $X$ 's horror at $Y^{\prime}=X^{\prime}$ 's intense, unpleasant, manifested, mental, reactive, active, excited-state, self-control-lossinflicting, temporary Gefühl caused by $Y$

Oper 1

: ᄀfühlen

Magn + IncepOper 1 : ᄀgeraten, ᄀausbrechen

fast FinFunc C $_{0}$

Caus $_{2}$Func $_{1}$

: ᄀverfliegen

: ᄀerregen

11. ENTTÄUSCHUNG, fem

Enttäuschung von $X$ über $Y$ wegen $Z$ 'X's disappointment at $Y$ because of $Z^{\prime}$ = $X^{\prime} s$ unpleasant, reactive, temporary Gefühl caused by $Y$ because of $Z$ 


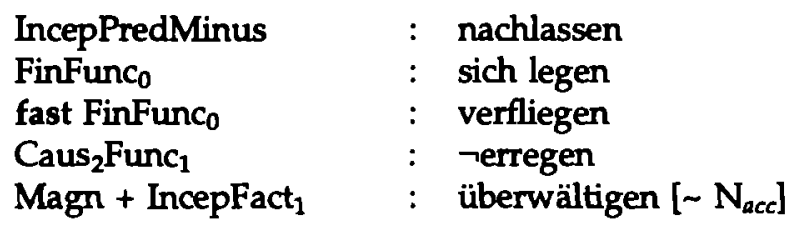

12. ENTZÜCKEN, neut

Entzücken von $X$ über $Y$ ' $X$ 's delight at $Y$ because of $Z^{\prime}=X^{\prime}$ 's intense, pleasant, manifested, mental, reactive, excited-state, temporary Gefühl caused by and directed at $Y$

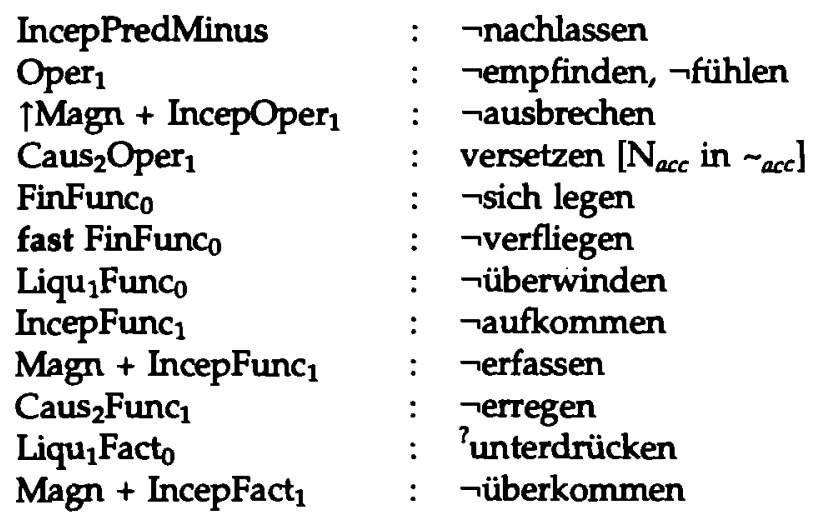

13. ERREGUNG, fem

Erregung von $X$ wegen $Y$ ' $X$ 's agitation because of $Y^{\prime}=X^{\prime} s$ manifestable, excited-state, temporary Gefühl caused by $Y$

Caus ${ }_{2}$ Oper $_{1} \quad:$ versetzen $\left[\mathrm{N}_{\text {acc }}\right.$ in $\left.\sim_{\text {acc }}\right]$

Magn + fast IncepFunc ${ }_{1}$ : packen $\left[\mathrm{N}_{\text {acc }}\right]$

Caus $_{2}$ Func $_{1}$ : ᄀhervorrufen

14. FREUDE, fem

Freude oon $X$ über $Y^{\prime} X^{\prime}$ 's joy at $Y^{\prime}=X^{\prime}$ 's pleasant, manifested, reactive, active, excited-state, self-control-loss-inflicting, permanent or temporary Gefühl caused by $Y$

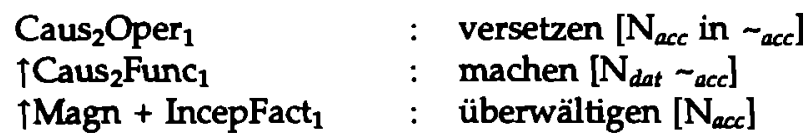

15. FURCHT, fem

Furcht von $X$ vor $Y$ wegen $Z$ ' $X$ 's fright of $Y$ because of $Z^{\prime}=X^{\prime} s$ unpleasant, mental, reactive, active, excited-state, permanent or temporary Gefühl caused by $Y$ 's $Z$ and directed at $Y$ 


$$
\begin{array}{|l|}
\hline \mathrm{Y}=\mathrm{II} \\
\hline \text { 1. vor } \mathrm{N}_{\text {dat }} \\
\text { 2. } z u \text { } \mathrm{V}_{\text {inf }} \\
\text { 3. daß PROP } \\
\hline
\end{array}
$$

IncepOper 1

$\mathrm{Caus}_{2} \mathrm{Oper}_{1}$

$\uparrow$ Caus $_{2}$ Func $_{1}$

CausContFunc,
: 'bekommen

: versetzen $\left[\mathrm{N}_{\text {acc }}\right.$ in $\left.\sim_{\text {acc }}\right]$

: einflößen $\left[\mathrm{N}_{d a t} \sim a c c\right]$, wecken [in $\left.\mathrm{N}_{d a t} \sim a c c\right]$

: schüren [in $\mathrm{N}_{d a t} \sim$ acc $]$

16. GROLL, masc

Groll von $X$ auf $Y$ wegen $Z$ ' $X$ 's grudge against $Y$ because of $Z$ ' $=X$ 's unpleasant, manifestable, mental, reactive, permanent or temporary Gefühl caused by $Y$ 's $Z$ and directed at $Y$

$$
\begin{array}{|l|}
\hline \\
\hline \text { 1. auf } \mathrm{N}_{a c c}
\end{array}
$$

$\uparrow O_{1}$

FinFunc $_{0}$

fast FinFunco

: hegen [gegen $\mathbf{N}_{a c c} \sim a c c$ ]

CausContFunc $_{1}$

: sich legen

: verfliegen

$\left(\right.$ Magn +) IncepFact ${ }_{1}$ : : überkommen

17. HASS, masc

Haß von $X$ auf $Y$ wegen $Z$ ' $X$ 's hatred towards $Y$ because of $Z^{\prime}=X^{\prime}$ 's intense, unpleasant, manifestable, attitudinal, active disapproving, self-control-loss-inflicting, permanent Gefühl caused by $Y^{\prime}$ 's $Z$ and directed at $Y$

$$
\begin{array}{|l|}
\hline Y=\mathrm{II} \\
\hline \text { 1. auf } \mathrm{N}_{a c c} \\
\hline
\end{array}
$$

$\uparrow$ Oper $_{1}$

IncepOper

Caus $_{2}$ Func $_{1}$

CausFunc $_{1}$

Caus,ContFunc $_{1}$
: hegen [gegen $\mathbf{N}_{a c c}$ - acc]

: bekommen [ $\left.\sim_{a c c}\right]$

: erregen [in $\mathbf{N}_{\text {dat }} \sim$ acc]

: wecken [in $\mathbf{N}_{d a t} \sim_{a c c}$ ]

: schüren [in $\mathbf{N}_{\text {dat }}$ - acc] 
18. HOFFNUNG, fem

Hoffnung oon $X$ auf $Y$ 'X's hope for $Y^{\prime}=X^{\prime}$ 's pleasant, mental, permanent Gefühl caused by $X$ 's belief and desire that $Y$ takes place

\begin{tabular}{|l|}
\hline $\mathrm{Y}=\mathrm{II}$ \\
\hline 1. auf $\mathrm{N}_{a c c}$ \\
2. daß PROP \\
\hline
\end{tabular}

IncepPredMinus

$\uparrow$ Oper 1

IncepOper 1

fast FinFunc $c_{0}$

Liqu $_{1}$ Func $_{0}$

Caus $_{2}$ Func $_{1}$

Caus $_{(2)}$ Func $_{1}$

Magn + IncepFunc

Magn + IncepFact
: nachlassen

: hegen $\left[\sim_{\text {acc }}\right]$, 'fühlen

: bekommen $\left[\sim_{a c c}\right]$

: verfliegen

: ᄀüberwinden

: einflößen $\left[\mathbb{N}_{\text {dat }} \sim a c c\right]$

: machen $\left[\mathbf{N}_{d a t} \sim\right.$ acc], wecken [in $\mathbf{N}_{d a t} \sim$ acc]

: ᄀerfassen

: ᄀüberkommen

19. LEIDENSCHAFT, fem

Leidenschaft von $X$ für $Y^{\prime} X^{\prime}$ 's passion for $Y^{\prime}=X^{\prime}$ 's intense, pleasant, manifestable, active, excited-state, self-control-loss-inflicting, permanent Gefühl directed at $Y$

$$
\begin{array}{|l|}
\hline \mathrm{Y}=\mathrm{II} \\
\hline \text { 1. für } \mathrm{N}_{\mathrm{acc}} \\
\hline
\end{array}
$$

$\uparrow$ Oper $_{1}$

FinFunc $c_{0}$

IncepFunc 1

Caus $_{(2)}$ Func $_{1}$

CausContFunc 1

Magn + IncepFact

$\uparrow$ Liqu $_{1}$ Facto $_{0}$
: hegen [für $\mathrm{N}$ - acc], ᄀempfinden, ᄀfühlen

: 'sich legen

: ᄀaufkommen

: wecken [in $\mathbf{N}_{\text {dat }} \sim_{\text {acc }}$ ]

: schüren [in $\mathrm{N}_{a t} \sim_{\text {acc }}$ ]

: überwältigen $\left[\mathrm{N}_{\text {acc }}\right]$

: 'überwinden

20. LIEBE, fem

Liebe oon $X z u Y$ wegen $Z$ 'X's love towards $Y$ because of $Z$ ' = X's intense, pleasant, manifestable, attitudinal, approving, excited-state, permanent Gefühl caused by $Y$ 's $Z$ and directed at $Y$ 


$$
\begin{array}{|l|}
\hline \mathrm{Y}=\mathrm{II} \\
\hline \text { 1. } z u \mathrm{~N}_{\text {dat }} \\
\text { 2. gegenüber } \mathrm{N}_{\text {dat }}
\end{array}
$$

$\uparrow_{\text {Oper }}$

FinFunc ${ }_{0}$

IncepFunc $_{1}$

Magn + IncepFunc 1

$($ Magn +$)$ IncepFact $_{1}$

$\uparrow$ Magn + IncepFact ${ }_{1}$
: I requires a modifier

: ᄀhaben

: ᄀsich legen

: ᄀaufkommen

: ᄀerfassen

: ᄀüberkommen

: überwältigen $\left[N_{a c c}\right]$

21. MITLEID, neut

Mitleid von $X$ mit $Y$ wegen $Z$ ' $X$ 's compassion for $Y$ because of $Z^{\prime}=X^{\prime} s$ unpleasant, mental, attitudinal, active, approving, permanent Gefühl directed at $Y$ because of $Z$

$$
\begin{aligned}
& \mathrm{Y}=\mathrm{II} \\
& \text { 1. mit } \mathrm{N}_{\text {dat }} \\
& \text { 2. gegenüber } \mathrm{N}_{\text {dat }}
\end{aligned}
$$

IncepPredMinus

IncepOper 1

fast FinFunc

Caus $_{(2)}$Func $_{1}$

Caus $_{2}$ Func $_{1}$

Magn + IncepFact
: nachlassen

: bekommen $\left[\mathbf{N}_{d a t} \sim \operatorname{acc}\right]$

: verfliegen

: einflößen [ $\left.\mathbf{N}_{\text {ecc }} \sim\right]$

: erregen, hervorrufen, wecken [in $\mathrm{N}_{d a t} \sim_{\text {acc }}$ ]

: überwältigen [ $\mathrm{N}_{\text {ecc }}$ ]

22. NER, masc

Neid von $X$ auf $Y$ wegen $Z$ ' $X$ 's envy of $Y$ because of $Z$ ' $=X^{\prime}$ 's unpleasant, permanent Gefühl directed at $Y$ because of $Z$

$$
\begin{array}{|l|}
\hline \\
\hline \text { 1. } \text { auf } \mathrm{N}_{\text {dat }} \\
\hline
\end{array}
$$

Oper $_{1}$

fast FinFunc

TCaus $_{2}$ Func $_{1}$

CausContFunc $_{1}$

: ᄀhaben

: verfliegen

: erregen, hervorrufen, wecken [in $\mathrm{N}_{d a t} \sim$ acc]

: schüren [in $\mathrm{N}_{\text {dat }} \sim_{\text {acc }}$ ] 
23. PANIK, fem

Panik von $X$ wegen $Y$ ' $X$ 's panic because of $Y^{\prime}=X^{\prime}$ 's intense, unpleasant, manifested, reactive, active, excited-state, self-controlloss-inflicting, temporary Gefühl caused by $Y$

$$
\begin{array}{|l|}
\hline \\
Y=\Pi \\
\hline \text { 1. } \text { oor } \mathrm{N}_{\text {dat }} \\
\hline
\end{array}
$$

Oper 1

IncepOper ${ }_{1}$

Caus $_{2}$ Oper $_{1}$

ᄀempfinden

fast FinFunc,

: bekommen [acc]

CausContFunc $_{1}$

$:$ versetzen $\left[\mathrm{N}_{a c c}\right.$ in $\sim$ acc $]$

: ᄀverfliegen

: schüren [in $\mathrm{N}_{\text {dat }} \sim$ acc $]$

24. REUE, fem

Reue von $X$ über $Y$ ' $X$ 's repentance of $Y^{\prime}=X^{\prime}$ 's unpleasant, manifestable, mental, permanent or temporary Gefühl caused by $Y$

\begin{tabular}{|c|c|}
\hline 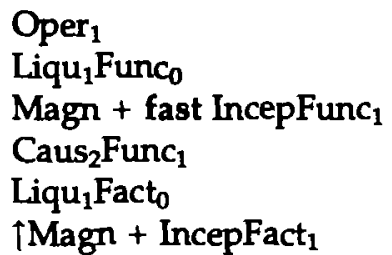 & $\begin{array}{ll}: & \neg \text { haben } \\
: & \neg \text { überwinden } \\
: & \text { packen }\left[\mathrm{N}_{a c c}\right] \\
: & \text { ᄀhervorrufen } \\
: & \text { ᄀunterdrüicken } \\
: & \text { überwältigen }\left[\mathrm{N}_{a c c}\right]\end{array}$ \\
\hline
\end{tabular}

25. RÜHRUNG, fem

Rührung von $X$ über $Y$ ' $X$ 's [emotion of being moved because of $Y^{\prime}$ ' = $X$ 's pleasant, manifestable, mental, reactive, active, excited-state, temporary Gefühl caused by $Y$
IncepPredMinus
: nachlassen
Caus $_{2}$Func $_{1}$
: ᄀerregen, ᄀhervorrufen
$\uparrow$ Magn + IncepFact
: überwältigen $\left[\mathbf{N}_{a c c}\right]$

26. SCHADENFREUDE, fem

Schadenfreude oon $X$ über $Y$ ' $X$ 's malicious joy of $Y$ ' $=X$ 's pleasant, mental, reactive, excited-state, temporary Gefühl caused by and directed at $Y$
IncepPredMinus
: ᄀnachlassen
FinFunc $_{0}$
: $\neg$ sich legen 
27. SCHAM, fem

Scham von $X$ über $Y$ ' $X$ 's shame because of $Y^{\prime}=X^{\prime}$ 's unpleasant, manifestable, mental, reactive, active, permanent or temporary Gefühl caused by $Y$

Oper $_{1}$

Caus $_{2}$ Func $_{1}$

$\uparrow$ Magn + IncepFact 1

Liqu $_{1}$ Fact $_{0}$
: 'fühlen, 'haben

: ᄀerregen

: überwältigen [ $\left.\mathbf{N}_{a c c}\right]$

: ᄀunterdrücken

28. SCHEU, fem

Scheu von $X$ vor $Y$ wegen $Z$ ' $X$ 's shyness in front of $Y$ because of $Z^{\prime}=$ $X$ 's unpleasant, manifestable, active, permanent or temporary Gefühl caused by $Y$ because of $Z$

$$
\begin{array}{|l|}
\hline \mathrm{Y}=\mathrm{II} \\
\hline \text { 1. vor } \mathrm{N}_{d a t} \\
\hline
\end{array}
$$

\begin{tabular}{|c|c|c|}
\hline IncepOper 1 & : & bekommen $\left[\sim_{\text {acc }}\right]$ \\
\hline Magn + IncepOper 1 & & $\neg$ geraten \\
\hline FinFunc $_{0}$ & : & sich legen \\
\hline fast Finfunc ${ }_{0}$ & : & verfliegen \\
\hline IncepFunc $_{1}$ & : & $\neg$ aufkommen \\
\hline Caus $_{2}$ Func $_{1}$ & 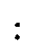 & ᄀhervorrufen \\
\hline Liqu $_{1}$ Fact $_{0}$ & : & $\neg$ unterdrücken \\
\hline
\end{tabular}

29. SCHRECK, masc

Schreck von $X$ wegen $Y$ ' $X$ 's terror because of $Y^{\prime}=X^{\prime}$ 's intense, unpleasant, manifestable, reactive, active, excited-state, self-controlloss-inflicting, temporary Gefühl caused by $Y$

IncepOper 1

Magn + IncepOper 1

$\mathrm{Caus}_{2} \mathrm{Oper}_{1}$

IncepFunc $_{1}$

Caus $_{2}$ Func $_{1}$

Liqu $_{1}$ Fact $_{0}$
: bekommen [DET $\left.\sim_{\text {acc }}\right]$

: ᄀausbrechen, ᄀgeraten

: versetzen $\left[\mathrm{N}_{\text {acc }}\right.$ in $\left.\sim_{\text {acc }}\right]$

: ᄀaufkommen

: ᄀerregen

: ᄀunterdrücken

30. STAUNEN, neut

Staunen von $X$ über $Y$ wegen $Z$ ' $X$ 's astonishment on $Y$ because of $Z$ ' = $X$ 's intense, manifested, mental, reactive, temporary Gefühl caused by $Y$ because of $Z$ 


\begin{tabular}{|c|c|}
\hline $\begin{array}{l}\text { Oper }_{1} \\
\uparrow \text { Magn } \text { IncepOper }_{1} \\
\text { Caus }_{2} \text { Oper }_{1} \\
\text { FinFunc } \\
\text { Magn + fast IncepFunc } \\
\text { Liqu }_{1} \text { Func }_{0}\end{array}$ & $\begin{array}{ll}: & \text { ᄀempfinden, } \neg \text { fühlen } \\
: & \text { ᄀausbrechen } \\
: & \text { versetzen }\left[\mathrm{N}_{a c c} \text { in } \text { acc] }\right. \\
: & \text { sich legen } \\
: & \text { packen }\left[\mathrm{N}_{a c c}\right] \\
: & \text { ᄀüberwinden }\end{array}$ \\
\hline
\end{tabular}

31. TRAUER, fem

Trauer von $X$ um $Y^{\prime} X^{\prime}$ 's sorrow for $Y^{\prime}=X^{\prime}$ 's unpleasant, manifestable, permanent Gefühl caused by $Y$

\begin{tabular}{|l|}
\hline $\mathrm{Y}=\mathrm{II}$ \\
\hline 1. $u \mathrm{~m} \mathrm{~N}_{a c c}$ \\
2. über $\mathrm{N}_{a c c}$ \\
3. (darüber), daß PROP \\
\hline
\end{tabular}

1) $\mathrm{C}_{I I .2}: \mathrm{N}$ denotes a fact. ${ }^{35}$

Oper $_{1}$

fast + FinFunc 0

Magn + IncepFact

Caus $_{2}$ Func $_{1}$

Liqu $_{1}$ Facto $_{0}$
: ᄀhaben

: verfliegen

: überwältigen $\left[\mathbf{N}_{a c c}\right]$

: ᄀhervorrufen

: ᄀunterdrücken

32. VERACHTUNG, fem

Verachtung von $X$ vor $Y$ wegen $Z$ ' $X$ 's contempt towards $Y$ because of $Z^{\prime}=X^{\prime}$ s unpleasant, mental, attitudinal, active, disapproving, permanent Gefühl caused by $Y$ 's $Z$ and directed at $Y$

†Oper 1 : hegen [für $\mathbf{N} \sim_{\text {acc }}$ ]

Magn + IncepFunc 1 : ᄀerfassen

†Caus ${ }_{2}$ Func $_{1}$ : wecken [in $\mathbf{N}_{\text {dat }} \sim_{\text {acc }}$ ]

33. VERÄRGERUNG, fem

Verärgerung von $X$ über $Y$ wegen $Z$ ' $X$ 's annoyance towards $Y$ because of $Z^{\prime}=X^{\prime}$ 's moderate, unpleasant, manifestable, mental, reactive, excited-state, temporary Gefühl caused by $Y$ 's $Z$ and directed at $Y$

Liqu $_{1}$ Func $_{0}$ : ᄀüberwinden

34. VERDRUSS, fem

Verdruß von $X$ über $Y$ wegen $Z$ ' $X$ 's vexation towards $Y$ because of $Z$ ' = 
$X$ 's moderate, unpleasant, manifestable, mental, reactive, excitedstate, temporary Gefühl because of Y's Z

$\begin{array}{ll}\text { IncepPredMinus } & : \text { ᄀnachlassen } \\ \text { Oper }_{1} & : \text { ᄀfühlen } \\ \text { Liqu }_{1} \text { Func }_{0} & : \text { ᄀüberwinden } \\ \text { Caus }_{(2)} \text { Func }_{1} & : \text { machen }\left[\mathbf{N}_{\text {dat }} \sim \text { acc }\right] \\ \text { Caus }_{2} \text { Func }_{1} & : \text { ᄀhervorrufen }\end{array}$

35. VERLEGENHEIT, fem

Verlegenheit von $X$ über $Y$ ' $X$ 's embarrassment of $Y$ ' $=X$ 's unpleasant, manifestable, mental, active, temporary Gefühl because of $Y$

IncepPredMinus : nachlassen

Magn + IncepOper ${ }_{1} \quad: \quad$ geraten $\left[\right.$ in $\left.\sim_{\text {acc }}\right]$

FinFunc $_{0} \quad:$ sich legen

fast FinFunc $c_{0} \quad:$ verfliegen

Liqu $_{1}$ Fact $_{0} \quad:$ ᄀunterdrücken

36. VERWUNDERUNG, fem

Verwunderung von $X$ über $Y$ ' $X$ 's astonishment because of $Y^{\prime}=X^{\prime} s$ moderate, manifestable, mental, temporary Gefühl caused by $Y$

Oper $_{1}$

Liqu $_{1}$ Func $_{0}$

: ᄀempfinden, ᄀfühlen

Caus $_{2}$ Func $_{1}$

: ᄀüberwinden

: erregen [in $\mathbf{N}_{\text {dat }} \sim$ acc]

37. VERZWEIFLUNG, fem

Verzweiflung von $X$ über $Y$ ' $X$ 's despair because of $Y^{\prime}=X^{\prime}$ 's intense, unpleasant, manifested, mental, reactive, active, excited-state, selfcontrol-loss-inflicting, temporary Gefühl caused by $Y$

\begin{tabular}{|l|}
\hline $\mathrm{Y}=\mathrm{II}$ \\
\hline 1. wegen $\mathrm{N}_{a c c}$ \\
2. über $\mathrm{N}_{a c c}$ \\
3. (darüber), daß PROP \\
\hline
\end{tabular}

$\uparrow$ Magn + IncepFact 1 : überwältigen $\left[\mathrm{N}_{\text {acc }}\right]$

Caus $_{2}$ Func $_{1}$ : ᄀerregen

Liqu $_{1}$ Facto $_{0} \quad:$ ᄀunterdrücken

38. wUT, fem

Wut von $X$ über $Y$ wegen $Z$ 'X's rage towards $Y$ because of $Z$ ' $=X$ 's 
intense, unpleasant, manifested, reactive, active, excited-state, selfcontrol-loss-inflicting, temporary Gefühl caused by $Y^{\prime} s \mathrm{Z}$ and directed at $Y$

$$
\begin{array}{|l|} 
\\
Y=\text { II } \\
\hline \text { 1. auf } \mathrm{N}_{a c c} \\
\text { 2. über } \mathrm{N}_{a c c}
\end{array}
$$

†Oper

IncepOper 1

Caus $_{2}$ Oper $_{1}$

CausContFunc $_{1}$
: haben [PRON/ DET - acc]

: bekommen [DET $\left.\sim_{\text {acc }}\right]$

: versetzen $\left[\mathrm{N}_{\text {acc }}\right.$ in $\left.\sim_{\text {acc }}\right]$

: schüren [in $\mathrm{N}_{d a t}$ ]

39. ZORN, masc

Zorn von $X$ über $Y$ wegen $Z$ ' $X$ 's wrath towards $Y$ because of $Z^{\prime}=X^{\prime} s$ intense, unpleasant, manifested, mental, reactive, active, excitedstate, self-control-loss-inflicting, temporary Gefühl caused by Y's Z and directed at $Y$

$$
\begin{array}{|l|}
Y=I \\
\hline 1 \text {. auf } N_{\text {acc }}
\end{array}
$$

†Oper

IncepOper,

Caus $_{2}$ Oper $_{1}$

TCaus $_{2}$ Func $_{1}$

CausContFunc $_{1}$

: haben [PRON/ DET - acc]

: bekommen [DET $\left.\sim_{\text {acc }}\right]$

: versetzen $\left[\mathbf{N}_{a c c}\right.$ in $\left.\sim a c c\right]$

: wecken [in $\mathrm{N}_{\text {dat }} \sim$ acc],

: schüren [in $\mathrm{N}_{\text {dat }} \sim$ acc $]$

40. ZUNEIGUNG, fem

Zuneigung von $X z u$ zegen $Z$ ' $X$ 's affection for $Y$ because of $Z$ ' = $X$ 's pleasant, mental, attitudinal, active, permanent Gefühl caused by $Y^{\prime}$ 's $Z$ and directed at $Y$

$$
\begin{array}{|l|}
\hline Y=I I \\
\hline \text { 1. } z u \mathrm{~N}_{\text {dat }} \\
\hline
\end{array}
$$

TOper $_{1}$

: haben [PRON/ DET acc für $\mathrm{N}_{a c c}$, hegen [ $\sim_{\text {acc }}$ für $\mathrm{N}_{\text {acc }}$ ]

$\uparrow$ Magn + IncepFact ${ }_{1} \quad:$ überwältigen $\left[\sim \mathrm{N}_{a c c}\right]$

Liqu $_{1}$ Fact $_{0}$

: ᄀunterdrücken 


\section{Notes}

1 Much work has been done on adequate representation of semantic and grammatical information in the lexicon (cf., e.g., Boguraev and Briscoe, 1987; Zemik and Dyer, 1987; Copestake, 1992). However, the problem of restricted lexical co-occurrence has not yet been addressed systematically. Although we are aware of some interesting ideas and proposals concerning this problem (cf. Borillo, 1992; Heid and Raab, 1989; Reuther, forthcoming), there are, as far as we know, no special studies dealing with an efficient representation of restricted lexical cooccurrence in dictionaries.

2 A substantive dependency between semantic subclasses of lexemes and the values of applicable LFs has been first stated, to our knowledge, in Heid and Raab (1989: 132-133), based on a description of French attitudinal emotion lexemes in Mel'čuk et al. (1984); cf. also Borillo (1992) and Reuther (forthcoming). For a general discussion of correlations between semantics and lexical co-occurrence, see, e.g., Pustejovsky et al. (1993).

3 It is impossible to give here an overview of this fast growing field in sufficient detail; we refer the reader, for example, to "Special Issue of Computational Linguistics on Inheritance" (1992).

4 Grammatical and Semantic inheritance classes overlap as well, but there this is a rather constrained phenomenon.

5 In the abridged definitions, we do not translate the generic lexeme of the field - GEFÜHL 'emotion', see Subsection 4.5.

6 A lexeme is a word taken in one well-specified sense and supplied with all the information determining its behavior when it is used in this sense.

7 We do not consider here definitions of non-predicate lexemes, which are irrelevant to our topic. A predicate lexeme is a lexeme whose meaning is a predicate (in logical sense): denotation of an action, an event, a state, a relation, a property, etc.

8 Semantic actants of a lexeme $L$ correspond to arguments of the predicate which is L's meaning.

9 Syntactic actants of a lexeme $L$ are major syntactic dependents of $L$ which correspond, roughly speaking, to L's semantic actants.

10 For further psychological studies on emotions and their vocabulary, see, e.g., de Rivera (1977); Dahl and Stengel (1978); Johnson-Laird and Oatley (1989).

11 Note that our semantic dimensions are trivial semantic features, in Apresjan's terminology (cf. Apresjan 1980: 27).

12 In the strict sense of the term 'lexicographic definition' as used in MTT, what we call here "abridged definitions" are not genuine definitions. An abridged definition is not designed to represent the meaning of the lexeme in all relevant details; rather, it is a hybrid formation for establishing the correlations between semantics and lexical co-occurrence.

13 Let it be emphasized that the semantic descriptions of German lexemes should not be judged on their English glosses. Thus, we translate STAUNEN as 'astonishment' and VERWUNDERUNG as 'amazement, but while the German lexemes are opposed as to the INTENSITY, their English correspondents are not: neither of 'astonishment' and 'amazement' is more intense than the other. Our glosses are no more than approximate pointers to the respective meaning; they are not to be taken at their face values.

14 Cf. Sommerfeldt and Schreiber (1983), where 'active' emotion lexemes are defined using a component called 'Tätigkeitsanteil'" 'activity part'; this component specifies the activity induced in the Experiencer by the emotion in question. 
15 We would like to take this opportunity to thank especially Sylvia Dickgießer for hunting down the emotion lexemes and their co-occurrence in the IDS corpora for us.

16 Let us give here three examples to illustrate the range of diversity in speakers' acceptability judgements.

Example 1: nachlassen '[to] get weaker'

According to one of the subjects, nachlassen does not co-occur with the following ten of the forty lexemes under consideration:

$\begin{array}{llll}\text { ANGST' } & \text { 'fear' } & \text { NEID } & \text { 'envy' } \\ \text { BEDAUERN } & \text { 'regret' } & \text { REUE } & \text { 'repentance' } \\ \text { EKEL } & \text { 'disgust' } & \text { SCHADENFREUDE } & \text { 'malicious joy' } \\ \text { ENTTÄUSCHUNG } & \text { 'disappointment' } & \text { SCHEU } & \text { 'shyness' } \\ \text { HASS } & \text { 'hatred' } & \text { VERACHTUNG } & \text { 'contempt }\end{array}$

Yet according to another subject, nachlassen does not co-occur with a different set of six lexemes:

$\begin{array}{llll}\text { BEDAUERN } & \text { 'regret' } & \text { REUE } & \text { 'repentance' } \\ \text { EMPÖRUNG } & \text { 'indignation' } & \text { RÜHRUNG } & \text { 'being moved' } \\ \text { ENTZÜCKEN } & \text { 'delight' } & \text { VERLEGENHEIT } & \text { 'embarrassment' }\end{array}$

That is, the two subjects agree in two cases only: *das Bedauern/ "die Reue ließ nach.

Example 2: hegen '[to] harbor'

As compared with nechlassen, the subjects' judgements were even more divergent for hegen; they varied between four (GROLL 'grudge', HOFFNUNG 'hope', LEIDENSCHAFT 'passion', ZUNEIGUNG 'affection') and twenty-four accepted lexemes. These twenty-four include, e.g., ANGST 'fear', BEDAUERN 'regret', RÜHRUNG 'being touched'.

Example 3: wecken '[to] wake'

All our subjects accepted Groll 'grudge'/ Hoffnung 'hope'/ Mitleid 'compassion'/ Zorn 'wrath' wecken. Other collocations accepted only by some of the subjects include, for example, ANGST 'fear'/ Bedauern 'regret'/ Neid 'envy' wecken.

"Full" in this sense means that the lexical entry presents all the information in full, "uncompressed" form, i.e. before carrying out the generalization.

18 The collocation Gefühl fühlen is usually avoided for stylistical reasons.

19 Of course, we do not consider here the other senses of bestellen, such as '[to] order ' [as in a restaurant], etc.

20 But not with FURCHT 'fright', VERÄRGERUNG 'annoyance', LIEBE 'love' ('Furcht) 'Verärgerung/' 'Liebe in ihm schüren lit. 'to fan fright/ annoyance/ love in him').

21 Instead of a subordinate clause an infinitive with $z u$ can always be used in an appropriate syntactic context: seine Freude (darüber), Elke heute zu sehen his joy to see Elke today'; therefore, being grammatically regular, it is not specified in the GP. Note that the prepositional pronoun is by no means optional with all lexemes. Cf. ihr Ekel davor, daß Hans den Salat mit den Händen mischt lit. 'Her disgust of it that Hans mixes the salad with his hands', but "ihr Ekel, daß Hans den Salat mit den Händen mischt lit. 'Her disgust that Hans mixes the salad with his hands'.

22 One might consider another avenue for possible generalizations concerning the GPs: obligatoriness/ optionality of the expression of a given DSyntA. Thus, the expression of DSyntA II is optional for three-argument emotion lexemes such as ANGST, ÄRGER, etc. (with the exception of attitudinals and EIFERSUCHT, see below):

(3) a. Hans hat Angst wegen Hugos Brutalität [=II]

lit. Thans has fear because of Hugo's brutality'. 
Hans hat Angst vor Hugo [=I] wegen dessen Brutalität [=III]

lit. 'Hans has fear of Hugo because of his brutality'.

Hans hat Angst

lit. 'Hans has fear'.

However, in attitudinals the DSyntA II cannot be omitted if the DSyntA III is expressed:

(4) a. Hans hat Achtung oor Hugo wegen dessen mutigen Auftretens

lit. 'Hans has respect of Hugo because of his courageous intervention'. but

b. "Hans hat Achtung wegen Hugos mutigen Auftretens

lit. 'Hans has respect because of Hugo's courageous intervention'.

EIFERSUCHT 'jealousy' equally cannot be used in German with its DSyntA III but without its DSyntA II:

(5) a. *ihre Eifersucht wegen der engen Freundschaft ihres Mannes mit seiner Kollegin her jealousy because of the intimate friendship of her husband with his (female) colleague'.

b. ihre Eifersucht auf die Kollegin ihres Mannes wegen deren enger Freundschaft

her jealousy of her husband's (female) colleague because of their intimate friendship'.

Yet, for the time being we do not consider this type of possible generalization.

Other lexemes of GEFÜHL include:

GEFÜHL $_{2}$ 'feeling of ...' as in

(7) a. Ein scharfes Gefïhl der Gefahr/ des Verlustes

'an acute feeling of danger/ loss'

b. Ein freudiges Gefühl der Erleichterung

'a joyful feeling of alleviation';

GEFÜHL 'feel' as in

(8) a. Elke hat ein gutes Gefïhl für Musik

Elke has a good feel for music'.

GEFÜHL 'feeling' as in

(9) Elke hatte das Gefühl, daß er sie betrïgt

Elke had the feeling that he cheats on her'.

GEFÜHLs 'sense of touch' as in

(10) Elke hat ein gutes Gefuihl in den Fingern

'Elke has a good sense of touch in her fingers'.

24 The semantic actant $W$ represents an actual specific emotion: dos Gefihl der Freude 'the feeling of joy <= dos erfreuliche Gefiuhl/ 'the joyful feeling'>, dos Gefïhl des Glücks 'the feeling of happiness' $<=$ dos glückliche Gefuihl 'the happy feeling' >, etc. When an emotion lexeme is used as the second argument of 'GEFÜHL $L_{1}$, it brings along its own lexical co-occurrence; cf. wilde Freude 'wild joy' $\rightarrow$ ein wildes Gefinhl der Freude 'the wild feeling of joy' or Zorm kam in ihm auf 'Wrath came up in him' $\rightarrow$ Ein zorniges Gefühl kam in ihm auf 'Wrathful feeling came up in him'. This is another type of lexical inheritance, which is not considered in this paper.

25 Note that in this context LFs are applied not to specific lexical units but to abstract semantic classes thereof; this actually means a revision and generalization of the concept of LF itself. Both sich richten and gelten are not on our list of $\mathrm{LF}$ verbs. 
27 Ausbrechen can also be a value of the LF Magn+IncepFunc: Begeisterung/Panik brach im Publikum aus lit. 'Enthusiasm/ Panic burst out in the public. Then the Experiencer must be a collective noun: Er brach in Begeisterung aus lit. 'He burst out in enthusiasm', but not "Begeisterung brach in ihm aus lit. 'Enthusiasm burst out in him'.

28 The very common collocation ÄRGER bekommen lit. '[to] get anger' (as in Wegen seiner schlechten Noten bekam Uwe zuhause mächtigen Ärger 'Because of his poor marks, Uwe got into much trouble at home') contains a different lexeme of ÄRGER meaning 'trouble', i.e. not an emotion lexeme.

29 In some collocations, bekommen cannot be replaced by its colloquial absolute synonym kriegen; consider. Er bekm neue Hoffnung 'He got new hope' but "Er kriegte neue Hoffnung.

30 Note that with ACHTUNG 'respect' the verb 'Ito] instill' requires as its first actant a predicate rather than a person:

(28) a. Sein couragiertes Auftreten fößßte uns Achtung ein

'His courageous appearance instilled respect into us'.

b. $\quad{ }^{n}$ Er flößte uns Achtung ein

lit. 'He instilled respect into us'.

This is different for angst 'fear':

(29) a. Sein hemmungsloses Auftreten flößte uns Angst ein

lit. 'His unscrupulous appearance instilled fear into us'.

b. Er fö̈ßte uns Angst ein

lit. 'He instilled fear into us'.

Therefore, an additional condition is required with einflößen '[to] instill' in the lexical entry of ACHTUNG 'respect'.

31 In fact, we found an example for in ENTSETZEN geraten in the corpus; however, the majority of the native speakers consulted found this co-occurrence ungrammatical.

32 Note that in the common collocation AUFREGUNG 'excitement' haben, AUFREGUNG means 'trouble' as in Mit diesen Burschen hat man nur Aufregung lit. With these guys one has only trouble'.

Machen '[to] make' also co-occurs with ÄRGER 'anger' and PANIK 'panic'. However, in these collocations, ÄRGER and PANIK denote not emotions but 'trouble' and 'fuss', respectively:

(30) a. In letzter Zeit machte Moyer der Geschäftsfïhrung ziemlich viel Ärger

Lately, Mayer made the management a lot of trouble'.

b. Der Chef macht heute wieder mal Panik!

'Once again, the boss is making much fuss today'.

34 In seine Begeisterung für Spieleisenbalinen his enthusiasm for toy railroads' we find another lexeme of BEGEISTERUNG with a different GP.

35 It is this restriction bearing on the govemed phrase "uber $N_{\text {acc }}$ " that precludes the generalization of über and deriber, da $\beta$, i.e. the reference to the common expression of Actant II of the reactive emotion lexemes. Compare, e.g., Entsetzen über Elkes Verhalten 'the horror over Elke's behavior'/ über Elke 'over Elke' but Trauer über Elkes Verhalten 'the sorrow over Elkes behavior'/ "über Elke; the correct expression: Trauer um Elke. 


\section{References}

Apresjan, Ju. D. 1980. Netrivial'nye semantičeskie priznaki i pravila vybora značenij [Non-trivial Semantic Features and Meaning Selection Rules]. Vosprijatie jazykovogo značenija: 27-49. Kaliningrad: Kaliningradskij Gos. universitet.

Apresjan, V. Ju. and Apresjan, Ju. D. 1993. Metafora v semantičeskom predstavlenii èmocij [Metaphor in the semantic representation of emotions]. Voprosy jazykoznanija (3): 27-35.

Arnold, W. and H.-J. Eysenck, R. Meili. 1980. Lexikon der Psychologie. Freiburg: Herder.

Averill, J.R. 1975. A Semantic Atlas of Emotion Concepts. Catalog of Selected Documents in Psychology 330(5); ms. 421.

Benson, M. 1989. The Structure of the Collocational Dictionary. International Joumal of Lexicography 2(1): 1-14.

Bergenholtz, H. 1980. Das Wortfeld "Angst". Stuttgart. Klett-Gotta.

Boguraev, B. and T. Briscoe. 1987. Large Lexicons for Natural Language Processing: Utilising The Grammar Coding System of LDOCE. Computational Linguistics 13(3-4): 203-218.

Borillo, A. 1992. Lexical and Syntactic Properties in the Lexicon: An Example of Predicative Nouns. Saint-Dizier, P. and E. Viegas (Eds.). 1992. 2nd Seminar on Computational Lexical Semantics: 26-34. Toulouse: Université Paul Sabatier.

Carpenter, R. 1992. The Logic of Typed Feature Structures. Cambridge: Cambridge University Press.

Copestake, A. 1992. The ACQUILEX LKB: Representation Issues in Semi-automatic Acquisition of Large Lexicons. Proceedings of the Third Applied Conference on Applied Natural Language Processing. Trento: Association for Computational Linguistics.

Dahl, H. and B. Stengel. 1978. A Classification of Emotion Words. Psychoanalysis and Contemporary Thought 1(2): 269-312.

De Rivera, J. 1977. A Structural Theory of the Emotions. New York: International Universities Press.

Firth, J. R. 1957. Modes of Meaning (1951). Papers in linguistics 1934-1951: 190-215. Oxford: Oxford University Press.

Gaatone, D. 1982. Grammaire géographique: réflexion sur la syntaxe des noms de pays en français. Le français moderne 50(2): 95-117.

Gaatone, D. 1992. Les verbes événementiels et les dictionnaires, quelques observations. Clas, A. (Ed.). 1992. Le mot, les mots, les bons mots: 95-108. Montréal: Les Presses de IUniversité de Montréal.

Gross, M. 1981. Les bases empiriques de la notion de prédicat sémantique. Langage 63: 7-52.

Hale, K. and J. Keyser. 1986. Some Transitivity Altemations in English. Lexicon Project Working Papers 7. Cambridge: Center for Cognitive Science, MTT.

Hausmann, F-J. 1985. Kollokationen im deutschen Wörterbuch: Ein Beitrag zur Theorie des lexikographischen Beispiels. Bergenholtz, H. and J. Mugdan (Eds.). 1985. Lexikographie und Grammatik: Akten des Essener Kolloquiums zur Grammatik im Wörterbuch 28.-30.6.1984. Lexicographica: Series Maior 3: 118-129. Tübingen: Max Niemeyer.

Heid, U. and S. Raab. 1989. Collocations in Multilingual Generation. Proceedings of the 4th. Conference of the European Chapter of the Association for Computational Linguistics: 130-136. Manchester. Association for Computational Linguistios.

Hoffmeister, J. 1955. Wörterbuch der philosophischen Begriffe. Hamburg.

Hudson, R. and N. Fraser. 1992. Inheritance in Wordgrammar. Computational Linguistics 18(2): 133-158. 
Iondanskaja, L.N. 1970. Popytka leksikografičeskogo tolkovanija gruppy russkix slov so značeniem cuvstva [An attempt of a lexicographic description of a group of Russian lexemes with the meaning of an emotion]. Masinnyj perevod i prikladnaja lingoistika 13: 3-26. Moscow.

Iordanskaja, LN. 1972. Leksikografičeskoe opisanie russkix vyraženij, oboznačajuščix fizičeskie symptomy čuvstv [Lexicographic description of Russian expressions denoting physical symptoms of emotions]. Masinnyj perevod $i$ prikladnaja lingvistika 16: 3-30. Moscow.

lordanskaja, L.N. 1973. Tentative Lexicographic Definitions for a Group of Russian Words Denoting Emotions. Kiefer, F. 1973. Trends in Soviet Theoretical Linguistics: 389-410. Dordrecht: Reidel.

Iordanskaja, L. N. and I.A. Mel'cuk. 1991. Semantics of Two Emotion Verbs in Russian: bojat'sja 'to be afraid' and nadejat'sja 'to hope'. Australion Journal of Linguistics 10: 307-357.

Johnson-Laind, P.N. and K. Oatley. 1989. The language of emotions: An analysis of a semantic field. Cognition and Emotion 3: 81-123.

Levin, B. 1989. English Verb Diathesis. Lexicon Project Working Papers 32. Cambridge: Center for Cognitive Science, MIT.

Levin, B. 1993. English Verb Classes. Chicago: Chicago University Press.

Mel'čuk, I.A. 1974. Opyt teorii lingoističeskix modelej "Smysk=>Tekst". Moscow: Nauka.

Mel'čuk, I.A 1981. Meaning-text Models: a Recent Trend in Soviet Linguistics. Annual Review of Anthropology 10: 27-62.

Mel'cuk, I.A. 1988. Dependency Syntax: Theory and Practice. Albany: State University of New York Press.

Mel'cuk, I.A. forthcoming. Lexical Functions: A Tool for the Description of Lexical Relations in a Lexicon. Wanner, L. (Ed.). Lexical Functions in Lexicography and Natural Language Processing.

Mel'cuk, I.A. and A.K. Žolkovskij. 1984. Explanatory Combinatorial Dictionary of Modern Russian. Vienna: Wiener Slawistischer Almanach.

Mel'čul, I.A. et al. 1984, 1988, 1992. Dictionnaire explicatif et combinatoire du frančais contemporain, I, II, III. Montréal: Presses de l'Université de Montréal.

Millex, G. et al. 1993. Fioe Papers on Wordnet, Technical Report 43. Cognitive Science Laboratory, Princeton University.

Nirenburg S. and V. Raskin. 1987. The Subworld Concept Lexicon and the Lexicon Management System. Computational Linguistics 13(3-4): 276-289.

Oatley, K. and P.N. Johnson-Laird. 1987. Towards a Cognitive Theory of Emotions. Emotion and Cognition 1(1): 29-50.

Ortony, A, G.L. Clore and M.A. Foss. 1987. The Referential Structure of the Affective Lexicon. Cognitive Science 11: 341-364.

Ortony, A., G.L. Glore and A. Collins. 1988. The Cognitive Structure of Emotions. Cambridge: Cambridge University Press.

Pitcher, G. 1965. Emotion Mind 74(295): 326-346.

Pollard, C. and LA. Sag. 1987, 1992. Information-based Syntax and Semantics: Volumes I, II. Stanford: Center for the Study of Language and Information.

Pustejovsky, J., S. Bergler and P. Anick 1993. Lexical Semantic Techniques for Corpus Analysis. Computational Linguistics 19(2): 331-358.

Pustejovsky, J. 1991. Towards a Generative Lexicon. Computational Linguistics 17(4): 409-441.

Reuther, T. forthcoming. On Dictionary Entries for Support Verbs: The Cases of Russian 'vesti', 'provodit', and 'proizvodit". Wanner, L. (Ed.). Lexical Functions in Lexicography and Natural Longuage Processing. 
Russel, J. A. 1980. A Circumplex Model of Affect. Jourmal of Personality and Social Psychology 39(6): 1161-1178.

Sommerfeldt, K.E. and H. Schreiber. 1983. Wörterbuch zur Valenz und Distribution der Substantive. Leipzig: VEB Bibliographisches Institut.

Thiele, W. 1965. Furcht und Angst. Jahrbuch für Psychologie, Psychotherapie und medizinische Anthropologie 13: 110-137.

Žolkovskij, A.K. and I.A. Mel'čuk. 1966. O sisteme semantičeskogo sinteza. I. Stroenie slovarja [On a System for Semantic Synthesis. I. Structure of the Dictionary]. Naučno-texničeskaja informacija (11): 48-55.

Wierzbicka, A. 1972. Semantic Primitives. Frankfurt am Main: Athenäum Verlag.

Wierzbicka, A. 1986. Human Emotions: Universal or Culture-Specific? American Anthropologist 88(3): 584-594.

Wierzbicka, A. 1992. Defining Emotion Concepts. Cognitive Science 16(4): 539-581.

Zajac, R. 1992. Inheritance and Constraint-Based Grammar Formalisms. Computational Linguistics 18(2): 159-182.

Zernik, U. and M. Dyer. 1987. The Self-Extending Phrasal Lexicon. Computational Linguistics 13(3-4): 308-327. 